\title{
Keys for the identification of families and genera of Atlantic shallow water ascidians
}

\author{
Rosana Moreira da Rocha ${ }^{1,4}$, Thais Bastos Zanata ${ }^{2}$ \& Tatiane Regina Moreno ${ }^{3}$ \\ ${ }^{1}$ Zoology Department, Universidade Federal do Paraná - UFPR, \\ CP 19020, CEP 81531-980, Curitiba, PR, Brazil \\ ${ }^{2}$ Ecology and Conservation grad program, Universidade Federal do Paraná - UFPR, Curitiba, PR, Brazil \\ ${ }^{3}$ Faculdades Integradas Espírita - UNIBEM, \\ Rua Tobias de Macedo Júnior, 246, Santo Inácio, CEP 82010-340, Curitiba, PR, Brazil \\ ${ }^{4}$ Corresponding author: Rosana Moreira da Rocha, e-mail: rmrocha@ufpr.br
}

ROCHA, R.M., ZANATA, T.B. \& MORENO, T.R. Keys for the identification of families and genera of Atlantic shallow water ascidians. Biota Neotrop. 12(1): http://www.biotaneotropica.org.br/v12n1/en/ abstract?identification-key+bn01712012012

Abstract: Here we present tabular keys for families and genera of ascidian species found in shallow waters in the Atlantic Ocean. Characters used in the keys are illustrated or shown in photos of dissected animals and we also provide generalized drawings of all genera. A list of species in each genus and their geographical distribution in the Atlantic is also included, totaling 461 species.

Keywords: Ascidiacea, Tunicata, taxonomy, checklist, geographic distribution.

ROCHA, R.M., ZANATA, T.B. \& MORENO T.R. Chaves de identificação de famílias e gêneros de ascídias de águas rasas no Atlântico. Biota Neotrop. 12(1): http://www.biotaneotropica.org.br/v12n1/pt/ abstract?identification-key+bn01712012012

Resumo: O trabalho apresenta chaves tabulares para famílias e gêneros de espécies de ascídias encontradas em águas rasas no Oceano Atlântico. Os caracteres usados nas chaves são ilustrados ou apresentados em fotos de animais dissecados e são apresentados também desenhos generalizados de todos os gêneros. Também foram incluídas listas de espécies em cada gênero e sua distribuição geográfica no Atlântico, totalizando 461 espécies. Palavras-chave: Ascidiacea, Tunicata, taxonomia, checklist, distribuição geográfica. 


\section{Introduction}

Ascidians form an ubiquitous portion of benthic communities in shallow tropical and temperate communities. Yet, the ascidian fauna of many regions is still poorly surveyed and the identification of species by non-specialists almost nonexistent. Most ecological studies of sessile communities include quite a few species, but frequently published lists include identification only to family or genus levels. The lack of field guides and identification keys for many regions is in part responsible for this situation.

The keys available are either not up to date (Van Name 1945, Monniot \& Monniot 1972, Monniot et al. 1991) or aimed toward Indo-Pacific species (Kott 1985, 1990, 1992, 2001). Recently, keys for the identification of local species within a few genera (Pérez-Portela et al. 2007 for Atlantic-Mediterranean Pycnoclavella) or a comparative table of characters (Oka et al. 2005 and Hirose et al. 2009 for photo-symbiotic Diplosoma in South Japan; Saito \& Okuyama 2003 for Japanese botryllids) have been published.

In the shallow Atlantic Ocean there are 461 known species, one seventh of known ascidian species in the world, around 2900 according to The World Register of Marine Species (Shenkar et al. 2010). Many genera and some families found in the Indian and Pacific oceans and do not occur in the Atlantic ocean. Thus, keys including all known families and genera of the world could easily mislead one trying to identify an Atlantic species. Moreover, some Ascidiacea families present morphological characters with a wide range of variability. Thus, here we narrowed the description of families and genera to consider only characters found in Atlantic species. We expect that with this simplified key and the numerous illustrations, researchers will feel more comfortable identifying their material and will provide a more accurate analysis of species geographic distribution and abundances.

\section{Material and Methods}

The list of Atlantic species was based initially in Zoobase, a database constructed by Karen Sanamyan and now incorporated in the World Register of Marine Species (Shenkar et al. 2010) and in the literature available for Atlantic species. Only shallow water species (maximum depth of $200 \mathrm{~m}$ ) between the latitudes $60^{\circ} \mathrm{N}$ and $55^{\circ} \mathrm{S}$ were considered, including Gulf of Mexico. Records from the Mediterranean Sea were not included.

Character states used in the keys were based on literature descriptions and when not available were coded "?" and when not applicable were coded "-". When different species in a taxon presented more than one state of a character both were coded and separated by a comma, while all the species presented both characters they were separated by a slash. The keys were constructed as tabular keys, where columns represent the different characters that define one taxon (family or genus) and rows represent each of the taxa. Such keys permit identification of the specimen even if some characters are missing or a structure is damaged and could not be checked and also permit fast comparison between taxa because similar taxa are organized together. The facility of adding new taxa and characters to tabular keys has also been pointed out (Newell 1970).

Besides the characteristics given in the tabular keys, we present a small description for all families and genera that will help to confirm identifications. Again, these descriptions only depict characters found in Atlantic species, thus they are not equivalent to complete descriptions of these taxons. Detailed description of the characters can be found in Monniot \& Monniot (1972), Monniot et al. (1991) and Kott (1985, 1990, 1992, 2001). A list of the Atlantic species known within each genus with their geographic distribution within the Atlantic will help the reader to sort the species to a given locality. Geographic distribution indicated does not differentiate natural and introduced populations. The identification to species level will demand the reading of original or complementary descriptions available in the literature and comparison of characters. References of the original description of the species were included in the reference list. (Table I)

\section{Cionidae Lahille, 1887}

Solitary ascidians with elongated body covered by a gelatinous and translucent tunic. Oral siphon with 6-8 lobes and atrial with six,

Table 1. Key for families in Atlantic Ascidiacea.

Tabela 1. Chave para famílias de Ascidiacea no Atlântico.

1. Life mode: S - Solitary (Figure 1a); C - Colonial (Figure 1b-d)

2. If colonial: E-Zooids completely embedded in the tunic (Figure 1b, c); P-Zooids partially embedded; I-Zooids not embedded (Figure 1d) 3. If colonial: $\mathrm{C}$ - Atrial siphons opening into cloacal systems (Figure 1c); $\mathrm{S}$ - Atrial siphons opening on the surface of the colony (Figure $1 \mathrm{~b}, \mathrm{~d})$

4. Body division: 1 - Not divided: alimentary canal at the side of the pharynx (Figure 2); 2 - Two parts, alimentary canal posterior to the pharynx; body divided into thorax and abdomen (Figure 3a); 3 - Three parts: thorax, abdomen (alimentary canal) and post-abdomen (gonads) (Figure 3b)

5. Position of the alimentary canal in relation to the pharynx: L - Left side (Figure 4a); R - Right side (Figure $4 \mathrm{~b})$; P - Posterior to the pharynx (Figure 4c)

6. Attachment of the gonads: B - to the body wall (Figures $2 \mathrm{~b}, 5 \mathrm{a}$ ); I - to the intestinal wall (Figures $2 \mathrm{a}, 3 \mathrm{a}, 5 \mathrm{~b}$ ); PA - In the post-abdomen (Figures 3b, 5c); $\mathrm{S}-$ in a abdominal sac

7. Oral tentacles: R - Ramified (Figure 2b, 6a); S - Simple (Figure 2a, 6b, c)

8. Number of folds on pharynx wall (one side) (Figure $2 b$ )

9. Longitudinal vessels: 0 - Absent (Figure 6d); C - Complete (Figure 6e); I - Incomplete (Figure 6f)

10. Pharyngeal papillae: 0 - Absent; $C$ - Papillae project into the lumen from complete longitudinal vessels (Figure $6 \mathrm{e}$ ); $\mathrm{S}$ - Papillae support longitudinal vessels without projecting into the lumen (Figure 6f, g); $\mathrm{U}$ - Papillae project into the lumen from incomplete longitudinal vessels

11. Pharyngeal stigmata: $\mathrm{C}$ - Curved; S - Straight (Figures 6d-f); P - Spiral (Figure 6g)

12. Dorsal lamina: $\mathrm{C}$ - Continuous (Figures $6 \mathrm{c}, \mathrm{h}$ ); $\mathrm{L}$ - Divided in languets (Figures $6 \mathrm{~b}, \mathrm{i}$ )

13. Number of pharyngeal rows of stigmata 
Table 1. Continued...

14. Brooding of embryos and larvae: 0 - No brooding; A - In the atrial cavity (Figure 7a); B - Brooding pouch (Figure 7b); O - In the oviduct; $\mathrm{T}$ - In the tunic (Figure 7c)

15. Larval adhesive papillae: $\mathrm{L}$ - Positioned in a line (Figures $7 \mathrm{~d}, \mathrm{f}, \mathrm{g}$ ); $\mathrm{T}$ - Positioned in a triangle (Figure 7e)

16. Number of larval adhesive papillae

17. Peculiar characteristics: B - Budding from the esophagus-rectum stalk (Figure 7h); D - Disk-like spicules in the tunic (Figure 8h); $\mathrm{G}$ - Stomach with digestive gland (Figure 2b, 19d); I larva with invaginated and tubular adhesive papillae (Figure 7g); L - Siphons with large and complex lobes (Figure 15a); $\mathrm{O}$ - longitudinal musculature formed by thin fibers oblique to the endostyle (Figure 8a) this character is also present in Distaplia; $\mathrm{S}$ - Renal sac on the right side of the body (Figure 2b, 8e); V - renal vesicles on the wall of the alimentary canal (Figure 8f); * Star-like spicules in the tunic (Figure 8i); W - longitudinal musculature organized in wide bands (Figure 8b)

\begin{tabular}{|c|c|c|c|c|c|c|c|c|c|c|c|c|c|c|c|c|c|}
\hline 1 & 2 & 3 & 4 & 5 & 6 & 7 & 8 & 9 & 10 & 11 & 12 & 13 & 14 & 15 & 16 & 17 & Family \\
\hline$S$ & - & - & 1,2 & $\mathrm{P}^{1}$ & I & $S$ & 0 & $\mathrm{C}$ & $\mathrm{C}$ & $S$ & $\mathrm{~L}$ & $>40$ & 0 & $\mathrm{~T}$ & 3 & W & Cionidae \\
\hline $\mathrm{S}, \mathrm{C}$ & $\mathrm{P}$ & $S$ & 2 & $\mathrm{P}^{1}$ & I & S & 0 & $\mathrm{C}, \mathrm{I}$ & S & S & $\mathrm{L}$ & $>20$ & 0 & $\mathrm{~T}$ & 3 & $\mathrm{O} / \mathrm{V}$ & Diazonidae \\
\hline S & - & - & 1 & $\mathrm{~L}$ & I & S & 0 & $\mathrm{C}$ & $\mathrm{C}$ & S & $\mathrm{C}$ & $>40$ & $0^{2}$ & $\mathrm{~T}$ & 3 & V & Ascidiidae \\
\hline S & - & - & 1 & $\mathrm{~L}$ & I & S & 0 & $0^{3}$ & $\mathrm{C}$ & $\mathrm{P}$ & $\mathrm{L}$ & 12 & 0 & $\mathrm{~T}$ & 3 & & Agneziidae \\
\hline S & - & - & 1 & $\mathrm{R}$ & I & S & 0 & $\mathrm{C}, \mathrm{I}$ & S & $\mathrm{S}, \mathrm{P}$ & $\mathrm{L}$ & $>20$ & A & $\mathrm{T}$ & 3 & & Corellidae \\
\hline $\mathrm{C}$ & I & S & 1 & $\mathrm{~L}$ & I & S & 0 & $\mathrm{C}, \mathrm{I}$ & $\mathrm{C}, \mathrm{S}, \mathrm{U}$ & S & $\mathrm{L}$ & $4-35$ & A & $\mathrm{L}$ & 3 & & Perophoridae \\
\hline $\mathrm{C}$ & E,P,I & S & 2 & $\mathrm{P}$ & I & S & 0 & 0 & 0 & S & $\mathrm{L}$ & $3-20$ & $\mathrm{~A}, \mathrm{O}$ & $\mathrm{T}, \mathrm{L}$ & $2-3^{4}$ & $\mathrm{I}^{5}$ & Clavelinidae \\
\hline $\mathrm{C}$ & $\mathrm{E}$ & S & 2 & $\mathrm{P}$ & I & S & 0 & 0 & 0 & S & $\mathrm{L}$ & $3-20$ & $\mathrm{~A}, \mathrm{~B}, \mathrm{O}$ & $\mathrm{L}$ & $>3$ & ${ }^{*}, \mathrm{D}^{7}$ & Polycitoridae \\
\hline $\mathrm{C}$ & $\mathrm{E}$ & S & 2 & $\mathrm{P}$ & I & S & 0 & 0 & 0 & S & $\mathrm{L}$ & $25-40$ & A & $\mathrm{T}$ & 3 & $\mathrm{~L}$ & Stomozoidae \\
\hline $\mathrm{C}$ & $\mathrm{E}$ & $\mathrm{C}$ & 2 & $\mathrm{P}$ & $\mathrm{I}, \mathrm{S}$ & S & 0 & 0 & 0 & S & $\mathrm{L}$ & 4 & B & $\mathrm{T}$ & 3 & & Holozoidae \\
\hline $\mathrm{C}$ & $\mathrm{E}$ & $\mathrm{C}$ & 2 & $\mathrm{P}$ & I & S & 0 & 0 & 0 & S & $\mathrm{L}$ & $3-4$ & $\mathrm{~T}$ & $\mathrm{~L}$ & $>2$ & $* / \mathrm{B}$ & Didemnidae \\
\hline $\mathrm{C}$ & $\mathrm{E}$ & $\mathrm{C}$ & 3 & $\mathrm{P}$ & PA & S & 0 & 0 & 0 & S & $\mathrm{L}$ & $6-20$ & $\mathrm{~A}, \mathrm{~B}, \mathrm{O}$ & $\mathrm{L}$ & 3 & & Polyclinidae \\
\hline $\mathrm{C}$ & E,I & S & 3 & $\mathrm{P}$ & PA & S & 0 & 0 & 0 & S & $\mathrm{L}$ & $12-22$ & $\mathrm{~A}, \mathrm{O}$ & $\mathrm{L}$ & 2 & & Euherdmaniidae \\
\hline $\mathrm{C}$ & $\mathrm{E}$ & S & 3 & $\mathrm{P}$ & PA & $S$ & 0 & 0 & 0 & $S$ & $\mathrm{~L}$ & 3 & $\mathrm{~B}, \mathrm{O}$ & $\mathrm{L}$ & 3 & & Pseudodistomidae \\
\hline $\mathrm{S}, \mathrm{C}$ & $\mathrm{E}$ & $\mathrm{S}, \mathrm{C}$ & 1,2 & $\mathrm{~L}, \mathrm{P}$ & $\mathrm{B}$ & $S$ & $0-4$ & $\mathrm{C}$ & 0 & $S$ & $\mathrm{C}$ & $>4$ & 0,A,B & $\mathrm{T}$ & 3 & & Styelidae \\
\hline$S$ & - & - & 1 & $\mathrm{~L}$ & $\mathrm{~B}, \mathrm{I}$ & $\mathrm{R}, \mathrm{S}^{8}$ & $>6$ & $\mathrm{C}$ & 0 & $\mathrm{~S}, \mathrm{C}, \mathrm{P}$ & C,L & $>20$ & 0 & $\mathrm{~T}$ & 3 & G & Pyuridae \\
\hline S & - & - & 1 & $\mathrm{~L}$ & $\mathrm{~B}, \mathrm{I}$ & $\mathrm{R}$ & $0,6-8$ & $\mathrm{C}^{9}$ & 0 & $\mathrm{P}$ & $\mathrm{C}$ & $>6$ & A & $\mathrm{T}$ & 3 & $\mathrm{G} / \mathrm{S}$ & Molgulidae \\
\hline
\end{tabular}

${ }^{1}$ Cionidae has a short abdomen with the alimentary canal almost horizontal while Diazonidae has a longer abdomen and vertical alimentary canal. ${ }^{2}$ Ascidia callosa incubates embryos in the atrial cavity. ${ }^{3}$ Agnesia glaciata is the only species in the Atlantic and it does not have longitudinal vessels but they are present in other non-Atlantic species of this genus. ${ }^{4}$ Clavelina brasiliensis is an exception with only one adhesive papilla. ${ }^{5}$ Only in the genus Pycnoclavella. ${ }^{6}$ Present in Eudistoma spiculiferum Millar, 1977. ${ }^{7}$ Only in the genus Cystodytes. ${ }^{8}$ Only Cratostigma present simple tentacles. ${ }^{9}$ Not obligatory characteristic.

with red dots between them. Longitudinal musculature organized in wide bands along entire body length and transverse musculature without a defined pattern (Figure $8 \mathrm{~b}$ ). Pharynx without folds, with complete longitudinal vessels and parastigmatic vessels usually present (Figure 15d). Abdomen very short with intestinal loop almost horizontal; stomach posterior to the pharynx with folded wall. Gonads included in the intestinal loop.

\section{Ciona Fleming, 1822 (Figure 9a)}

Only genus in the family, with same description.

Ciona intestinalis (Linnaeus, 1767): Greenland, Davis Strait, eastern Canada, U.S. (New England, California), Brazil (Rio de Janeiro, São Paulo), Chile (Strait of Magellan), Svalbard Islands, Iceland, Faroe Islands, Norway, Sweden, Denmark, Netherlands, Scotland, UK, Spain, Morocco, Cape Verde, Senegal, Angola, South Africa.

\section{Diazonidae Garstang, 1891 (Table 2)}

Solitary or colonial ascidians, only the abdomen embedded in the tunic in colonial forms. The tunic is usually not encrusted. Siphons with six lobes. Body longitudinal musculature oblique to the endostyle, ramified and anastomosed (Figure 8a), forming two thin bands along the mid line of the abdomen. Stomach wall smooth outside but folded inside. Renal vesicles could be present.
Table 2. Key for genera in Diazonidae

Tabela 2. Chave para gêneros em Diazonidae

1. Life mode: C - Colonial; S - Solitary

2. Coloration in preserved animals: $G$ - Only projected zooids purple but the base of the colony uncolored or greenish; $\mathrm{P}$ - Purple

3. Velum of the siphon: $\mathrm{P}$ - Present (Figure 15b); 0 - Absent 4. Number of oral tentacles

\begin{tabular}{ccccc}
\hline $\mathbf{1}$ & $\mathbf{2}$ & $\mathbf{3}$ & $\mathbf{4}$ & Genera \\
\hline S,C & $\mathrm{P}$ & $\mathrm{P}$ & $>20$ & Rhopalaea \\
C & $\mathrm{G}$ & 0 & $<20$ & Diazona \\
\hline
\end{tabular}

\section{Rhopalaea Philippi, 1843 (Figure 9b)}

Solitary ascidians, but sometimes two individuals are found connected by a slender layer of tunic. Tunic dark purple without encrustation, with apical and short siphons. Body wall muscles only in the thorax, oblique, between the dorsal margin and the endostyle. Oral siphon with a velum (Figure 15b). Pharynx without folds, but with complete longitudinal vessels. Abdomen with numerous renal vesicles.

Rhopalaea abdominalis (Sluiter, 1898a): U.S. (Florida), Cuba, Guadeloupe, Mexico, Belize, Panama, Venezuela. 

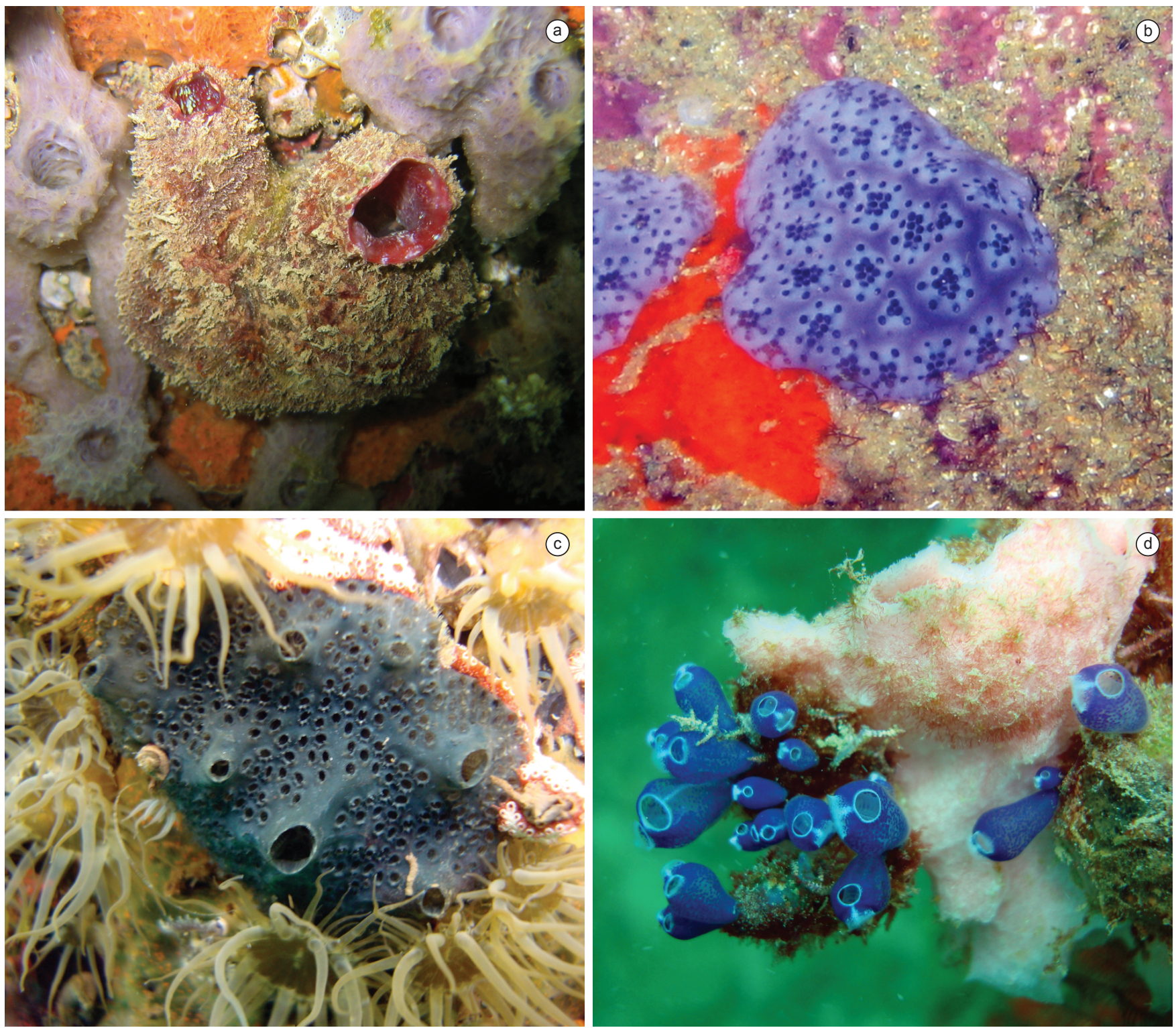

Figure 1. a) Herdmania pallida - solitary; b) Eudistoma sp. - colony with both siphons opening directly on the surface of the tunic; the circle of atrial siphons is inside the circle of oral siphons; c) Polyclinum constellatum - small apertures are the oral siphons, large apertures are common clocal apertures; d) Clavelina puertosecensis - Zooids each with independent oral and atrial siphons, not embedded in a common tunic but linked only at the base.

Figura 1. a) Herdmania pallida - solitária; b) Eudistoma sp. - Colônia com ambos os sifões abrindo diretamente sobre a superfície da túnica, o círculo de sifões atriais está dentro do círculo dos sifões orais; c) Polyclinum constellatum - pequenas aberturas são os sifões orais, grandes aberturas são aberturas clocais comuns; d) Clavelina puertosecensis - zoóides independentes, cada um com sifões oral e atrial, não embebidos em uma túnica comum, mas unidos apenas pela base.

\section{Diazona Savigny, 1816 (Figure 9c)}

Colonial ascidian with the anterior part of zooids free, but posterior part embedded inside the tunic. The colonies are massive and can be as large as $40 \mathrm{~cm}$ in diameter and $20 \mathrm{~cm}$ high, with zooids up to $5 \mathrm{~cm}$ long. Both oral and atrial siphons in each zooid with strong sphincters. Oral siphon without a velum.

Diazona geayi Caullery, 1914: French Guyana

Diazona violacea Savigny, 1816: U.K., Spain, France

Ascidiidae Adams, 1858 (Table III)

Solitary ascidians with gelatinous or cartilaginous and translucent tunic. Siphons with six or more lobes, and red dots between them. Body wall musculature developed only on the right side (Figure 8c). Dorsal lamina continuous. Alimentary canal usually large, with descending limb and rectum dilated in some species (Figure 19a). Renal vesicles present on the wall of the alimentary canal (Figure 8f). Ovary usually inside the intestinal loop, while the male follicles spread over the intestine wall.

\section{Ascidia Linnaeus, 1767 (Figure 10a)}

Solitary animals with gelatinous and translucent tunic, sometimes with long or mammillate projections. Variable body wall colors. Siphons usually with 6-8 lobes, some species with more than 12 ; lobe margins plain or with small projections in some species. Pharyngeal papillae protruding inside the lumen of the pharynx; intermediate papillae might be present (Figure 15e). Dorsal lamina continuous. Alimentary canal on the left side, usually with both intestinal loops well marked and sometimes with dilated posterior intestine. 

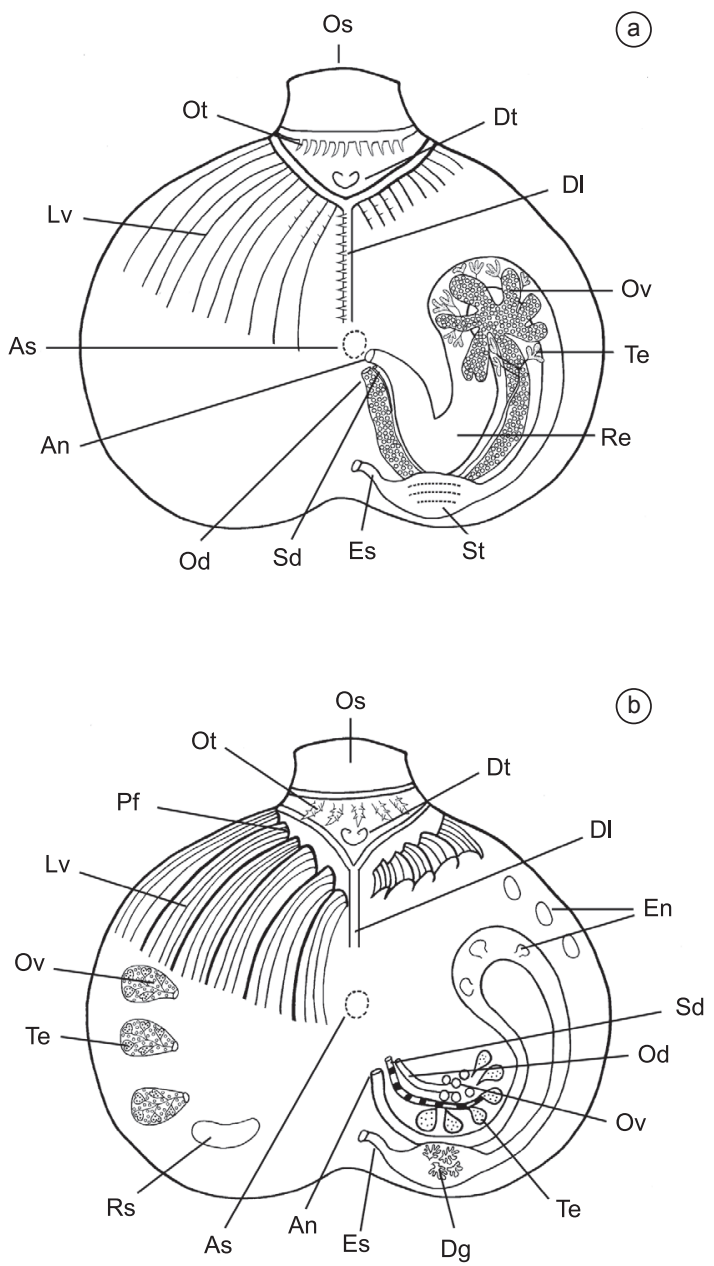

Figure 2. Solitary adult general characteristics. a) Phlebobranchia; b) Stolidobranchia. An = anus, As = atrial siphon, Dg = digestive gland, $\mathrm{Dl}=$ dorsal lamina, $\mathrm{Dt}=$ dorsal tubercle, $\mathrm{En}=$ endocarps, $\mathrm{Es}=$ esophagus, $\mathrm{Lv}=$ longitudinal vessels, $\mathrm{Od}=$ oviduct, $\mathrm{Os}=$ oral siphon, $\mathrm{Ot}=$ oral tentacles, $\mathrm{Ov}=$ ovary, $\mathrm{Pf}=$ pharyngeal folds, $\mathrm{Re}=$ rectum, $\mathrm{Rs}=$ renal sac, $\mathrm{Sd}=$ sperm duct, $\mathrm{St}=$ stomach, $\mathrm{Te}=$ testis .

Figura 2. Características gerais de uma ascídia solitária adulta a) Phlebobranchia; b) Stolidobranchia. An ânus = As = sifão atrial, $\mathrm{Dg}=$ glândula digestiva, $\mathrm{Dl}=$ lâmina dorsal, $\mathrm{Dt}=$ tubérculo dorsal, En $=$ endocarpos, Es $=$ esôfago, $\mathrm{Lv}=$ vasos longitudinais, $\mathrm{Od}=$ oviduto, Os = sifão oral, $\mathrm{Ot}=$ tentáculos orais, $\mathrm{Ov}=$ ovário, $\mathrm{Pf}=$ dobras da faringe, $\mathrm{Re}=$ reto, $\mathrm{Rs}=$ saco renal, $\mathrm{Sd}=$ espermiduto, $\mathrm{St}=$ estômago, $\mathrm{Te}=$ testículo .

Table 3. Key for genera in Ascidiidae

Tabela 3. Chave para gêneros em Ascidiidae

1. Duct of the neural gland: 1 - One aperture at the dorsal tubercle; $>1$ - Many accessory apertures along the duct opening into the atrial cavity (Figure 15c)

2. Pharyngeal papillae: $\mathrm{C}-$ Papillae project into the lumen of the pharynx from complete longitudinal vessels (Figure 6e); S - Papillae support longitudinal vessels without projecting into the lumen.

\begin{tabular}{ccc}
\hline $\mathbf{1}$ & $\mathbf{2}$ & Genera \\
\hline 1 & $\mathrm{C}$ & Ascidia \\
1 & $\mathrm{~S}$ & Ascidiella \\
$>1$ & $\mathrm{C}$ & Phallusia \\
\hline
\end{tabular}
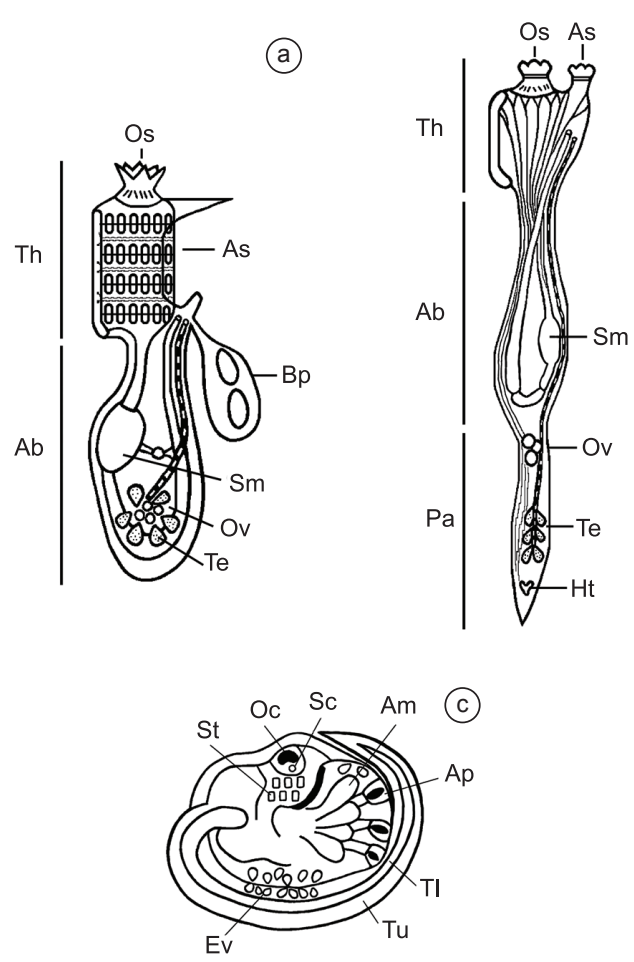

Figure 3. Colonial Aplousobranchia zooids and a generalized larva. a) Zooid with two body parts; b) Zooid with three body parts; c) Incubated larva (unhatched). $\mathrm{Ab}=$ abdomen, $\mathrm{Am}=$ lateral ampulla, $\mathrm{Ap}=$ adhesive papilla, $\mathrm{As}=$ atrial siphon, $\mathrm{Bp}=$ brooding pouch, $\mathrm{Ev}=$ ectodermic vesicles, $\mathrm{Ht}=$ heart, $\mathrm{Oc}=$ ocellum, $\mathrm{Os}=$ oral siphon, $\mathrm{Ov}=$ ovary, $\mathrm{Pa}=$ post-abdomen, $\mathrm{Sc}=$ statocyte, $\mathrm{Sm}=$ stomach, $\mathrm{St}=$ stigmata, $\mathrm{Te}=$ testis, $\mathrm{Th}=$ thorax, $\mathrm{TL}=$ tail, $\mathrm{Tu}=$ tunic.

Figura 3. Zoóides de Aplousobranchia e uma larva generalizada. a) Zooide com corpo dividido em duas partes; b) Zooide com corpo dividido em três partes; c) Larva incubada. Ab = abdômen, Am = ampola lateral, Ap = papila adesiva, $\mathrm{As}=$ sifão atrial, $\mathrm{Bp}=$ bolsa incubadora, $\mathrm{Ev}=$ Vesículas ectodérmicas, $\mathrm{Ht}=$ coração, $\mathrm{Oc}=$ ocelo, $\mathrm{Os}=$ sifão oral, $\mathrm{Ov}=$ ovário, $\mathrm{Pa}=$ pós-abdômen, $\mathrm{Sc}=$ estatócito, $\mathrm{Sm}=$ estômago, $\mathrm{St}=$ fenda (estígmata), $\mathrm{Te}=$ testículo, $\mathrm{Th}=$ tórax, $\mathrm{TL}=$ cauda, $\mathrm{Tu}=$ túnica.

Ascidia achimotae Millar, 1953: Ghana.

Ascidia archaia Sluiter, 1890: Haiti, Guadeloupe, Belize, Panama, Curaçao.

Ascidia aximensis Millar, 1953: Senegal, Sierra Leone, Ghana. Ascidia bocatorensis Bonnet \& Rocha, 2011a: Panama.

Ascidia callosa Stimpson, 1852: Greenland, Canada, U.S., Svalbard Islands, Iceland, Faroe Islands, Norway, Sweden.

Ascidia challengeri Herdman, 1882: Strait of Magellan, Antarctic.

Ascidia collini Bonnet \& Rocha, 2011a: Panama.

Ascidia conchilega Müeller, 1776: Norway, Sweden, Shetland

Islands, Orkney Islands, U.K., Scotland, France.

Ascidia corallicola Bonnet \& Rocha, 2011a: Panama.

Ascidia curvata (Traustedt, 1882): Bermuda, U.S. (Florida),

Cuba, Jamaica, Puerto Rico, Guadeloupe, Martinique, Saint Thomas, Panama, Aruba, Curaçao, Bonaire, Brazil (Pernambuco to Paraná).

Ascidia fistulosa Monniot \& Monniot, 1967: Azores, Cape Verde. 

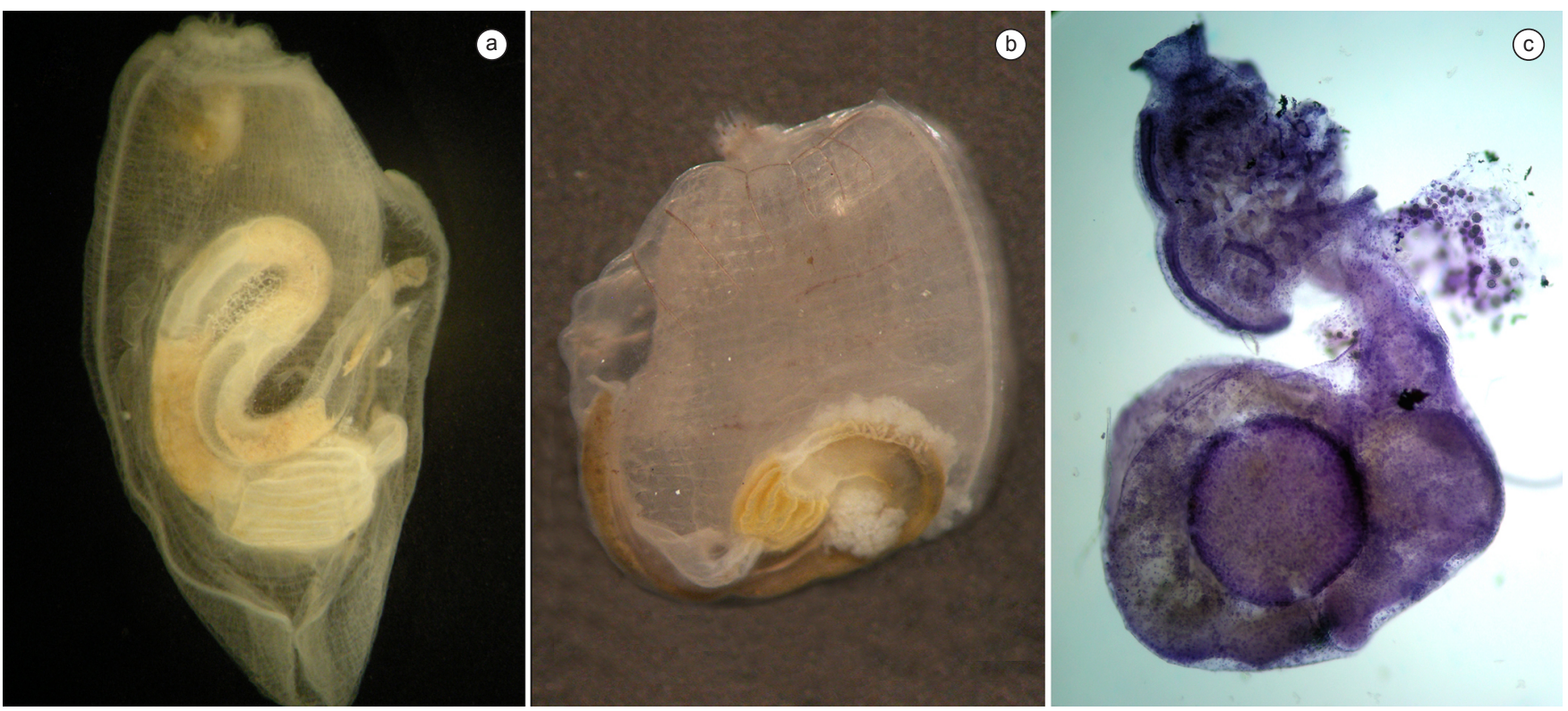

Figure 4. Alimentary canal position. a) Ascidia curvata - on the left side; b) Corella minuta - on the right side; c) Didemnum cineraceum - under the thorax. Figura 4. Posição do trato digestivo. a) Ascidia curvata - no lado esquerdo; b) Corella minuta - no lado direito; c) Didemnum cineraceum - sob o tórax.

Ascidia interrupta Heller, 1878: Bermuda, U.S., Bahamas, Cuba, Jamaica, Puerto Rico, Saint Thomas, Guadeloupe, Belize, Panama, Aruba, Bonaire, Curaçao, Venezuela, Brazil (Bahia), Azores.

Ascidia involuta Heller, 1875: Sierra Leone.

Ascidia mentula Müeller, 1776: U.K., Spain.

Ascidia meridionalis Herdman, 1880: Argentina, Strait of Magellan.

Ascidia molguloides Monniot, 1974: Azores.

Ascidia monnioti Bonnet \& Rocha, 2011a: Panama.

Ascidia multitentaculata (Hartmeyer, 1912): Brazil (Ceará,

Bahia, Espírito Santo, São Paulo), South Africa.

Ascidia muricata Heller, 1874: Azores.

Ascidia nordestina Bonnet \& Rocha, 2011b: Brazil (Pernambuco, Bahia)

Ascidia obliqua Alder, 1863: Greenland, Davis Strait, Canada, U.S. (Maine to Connecticut), Iceland, Faroe Islands, Norway, Skagerrak Strait, Sweden, North Sea, Shetland Islands, Scotland, France, Cape Verde.

Ascidia panamensis Bonnet \& Rocha, 2011a: Panama. Ascidia papillata Bonnet \& Rocha, 2011b: Brazil (Bahia) Ascidia prona Monniot \& Monniot, 1994a: Senegal.

Ascidia prunum Müeller, 1776: Greenland, Davis Strait, Canada, U.S. (Maine to Connecticut), Svalbard Islands, Bear Island, Iceland,

Norway, Skagerrak Strait, North Sea, Shetland Islands.

Ascidia santosi Millar, 1958: Brazil (São Paulo).

Ascidia scalariforme Bonnet \& Rocha, 2011b: Brazil (Bahia, São Paulo)

Ascidia sydneiensis Stimpson, 1855: U.S., Cuba, Puerto Rico, Anguilla, Grenada, Guadeloupe, Saint Thomas, Panama, Colombia, Curaçao, Brazil (Ceará, Espírito Santo to Santa

Catarina), Cape Verde, Sierra Leone, South Africa.

Ascidia tenue Monniot, 1983a: Bermuda, Guadeloupe, Brazil

(Bahia, São Paulo, Paraná, Santa Catarina).

Ascidia translucida Sluiter, 1890: South Georgia.

Ascidia virginea Müeller, 1776: Svalbard Islands, Faroe Islands,

Norway, Sweden, Shetland Islands, U.K., English Channel.

Ascidia xamaycana Millar \& Goodbody, 1974: Jamaica.

\section{Ascidiella Roule, 1883 (Figure 10a)}

Very similar to Ascidia, distinguished by the lack of projecting papillae on the longitudinal vessels inside the lumen of the pharynx.

Ascidiella aspersa (Müeller, 1776): U.S. (Maine to Massachusetts), Argentina, Norway, Sweden, Shetland Islands, U.K., Scotland, English Channel, Spain, Senegal, South Africa. Ascidiella scabra (Müeller, 1776): Faroe Islands, Norway, Sweden, Denmark, Scotland, U.K., English Channel.

Ascidiella senegalensis Michaelsen, 1914: Senegal, Sierra Leone, Ghana.

\section{Phallusia Savigny, 1816 (Figure 10a)}

Very similar to Ascidia, distinguished by the posterior position of the neural gland, connected to the dorsal tubercle by a long duct with accessory openings toward the atrial cavity (Figure 15c). Oral siphons with usually more than eight lobes. Intermediate pharyngeal papillae might be present (Figure 15e).

Phallusia caguayensis (Millar \& Goodbody, 1974): Jamaica.

Phallusia fragilis Bonnet \& Rocha, 2011a: Panama.

Phallusia mammillata (Cuvier, 1815): U.K., Spain.

Phallusia nigra Savigny, 1816: Bermuda, U.S. (Florida), Cuba, Jamaica, Haiti, Puerto Rico, Saint Thomas, Grenada, Guadeloupe, St. Martin, St. Croix, St. Vincent, Belize, Panama, Curaçao, Bonaire, Venezuela, Brazil (Ceará, Alagoas to São Paulo), Guinea, Angola.

Phallusia recifensis Millar, 1977: Brazil (Maranhão, Pernambuco).

\section{Agneziidae Huntsman, 1912}

Solitary ascidians with thin and translucent tunic, sometimes encrusted by sand. Pharynx with 12 rows of spiral stigmata, which do not form infundibula (as Corella in Figure 6g); longitudinal vessels absent. Dorsal lamina divided in languets. Closely resembles Corellidae, but the alimentary tract is on the left side of the body.

Agnezia Michaelsen, 1898 (Figure 10b)

Same description of the family. 


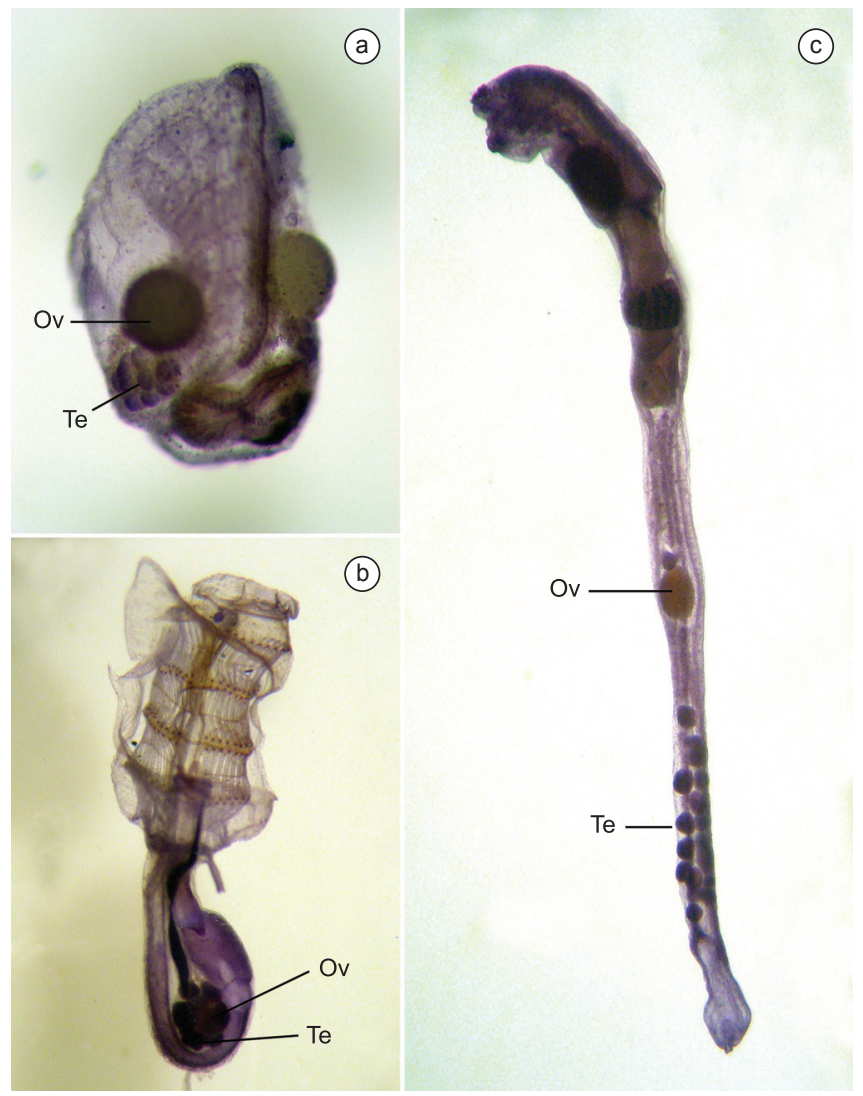

Figure 5. Position of the gonads. a) Botryllid - attached to the body wall; b) Distaplia bermudensis - in the intestinal loop; c) Aplidium accarense - in the post-abdomen. $\mathrm{Ov}=$ ovary; $\mathrm{Te}=$ testis.

Figura 5. Posição das gônadas. a) Botryllid - ligado à parede do corpo; b) Distaplia bermudensis - na alça intestinal; c) Aplidium accarense - no pós-abdome. Ov = ovário; Te = testículo.

Agnezia glaciata Michaelsen, 1898: Strait of Magellan, Tierra del Fuego, South Africa.

\section{Corellidae Lahille, 1888 (Table 4)}

Solitary ascidians, some with spiral stigmata not forming infundibula (Figure 6g). Alimentary tract on the right side of the body, intestine oriented vertically (Figure $4 b$ ).

\section{Chelyosoma Broderip \& Sowerby, 1830 (Figure 10c)}

Small ascidian up to $2 \mathrm{~cm}$ long, flattened dorsoventrally. Tunic thick with horny plates or scales on the dorsal region, forming an oval flat region; each siphon surrounded by six plates. Spiral stigmata irregularly arranged, without correspondence with the net of vessels. Dorsal lamina divided in languets. Stomach of $C$. macleayanum with areolate ornamentation.

Chelyosoma macleayanum Broderip \& Sowerby, 1830: Greenland, Canada, U.S. (Maine, Massachusetts), Iceland, Norway.

\section{Corella Alder and Hancock, 1870 (Figure 10d)}

Solitary ascidians with oblong or square (Figure 4b), and laterally compressed body, covered by a gelatinous and transparent tunic, sometimes tinted with yellow, red or other shades. Oral siphon with 6-8 lobes and atrial with six. Oral tentacles numerous and filiform. Spiral stigmata regularly arranged with every four adjacent spirals converging to the same central point. Dorsal lamina divided in languets. Stomach wall with a few longitudinal folds, anterior to the intestinal loop (Figure 4b).
Table 4. Key for genera in Corellidae.

Tabela 4. Chave para gêneros em Corellidae.

1. Tunic: $G$ - Gelatinous and translucent, rarely with any incrustations; $\mathrm{L}$ - Dorsal region thick forming a lid that cover the siphons; P - Thick with plates or scales at the dorsal region, which is oval and flat

2. Pharyngeal stigmata: I - Spiral and irregularly arranged; $\mathrm{R}$ - Spiral and regularly arranged, every four adjacent spirals converging to the same central point; $\mathrm{S}$ - Straight

3. Stomach wall: $\mathrm{A}$ - areolated or pitted; $\mathrm{F}-$ folded

\begin{tabular}{cccc}
\hline $\mathbf{1}$ & $\mathbf{2}$ & $\mathbf{3}$ & Genera \\
\hline P & I & A & Chelyosoma \\
G & R & F & Corella \\
L & S & F & Rhodosoma \\
\hline
\end{tabular}

Table 5. Key for genera in Perophoridae.

Tabela 5. Chave para gêneros em Perophoridae.

1. Zooid Size

2. Number of rows of stigmata

3. Male follicles: F - Large and few concentrated in the center of the intestinal loop; $\mathrm{N}$ - Small but elongate and numerous forming a crescent inside the intestinal loop

\begin{tabular}{cccc}
\hline $\mathbf{1}$ & $\mathbf{2}$ & $\mathbf{3}$ & Genera \\
\hline$<5 \mathrm{~mm}$ & $4-5$ & $\mathrm{~F}$ & Perophora \\
$>5 \mathrm{~mm}$ & $>10$ & $\mathrm{~N}$ & Ecteinascidia \\
\hline
\end{tabular}

Corella borealis Traustedt, 1886: Greenland, Canada, U.S. (Massachusetts), British Islands.

Corella eumyota Traustedt, 1882: Argentina, Antarctic, South Africa.

Corella minuta Traustedt, 1882: Haiti, Anguilla, Saint Thomas, Saba, Panama, Curaçao, Brazil ? (Bahia).

Corella parallelogramma (Müeller, 1776): Norway, Sweden, British Islands, Scotland.

\section{Rhodosoma Ehrenberg, 1828 (Figure 10e)}

Animals $2-3 \mathrm{~cm}$ long, uncolored or yellow with reddish siphons. Tunic with an anterior flat lid that covers both siphons and contains many projections and spines. Longitudinal musculature forming thick bands, displaced to the sides of the siphons and connected to the tunic to move the lid. Pharynx with straight stigmata. Dorsal lamina divided in languets. Stomach wall with a few longitudinal folds, anterior to the intestinal loop.

Rhodosoma turcicum (Savigny, 1816): U.S. (Florida), Cuba,

Jamaica, Puerto Rico, St. Croix, St. Thomas, Guadeloupe,

Panama, Curaçao, Bonaire, Brazil (Bahia, Rio de Janeiro).

\section{Perophoridae Giard, 1872 (Table 5)}

Colonial ascidians with zooids linked by stolons and covered by a thin and usually translucent tunic (Figure 7i). Body round or elongate, usually greenish or yellowish. Siphons opening on the surface of the colony, with many lobes, both with independent apertures. Larvae large with adhesive papillae arranged linearly.

\section{Perophora Wiegmann, 1835 (Figure 11a)}

Zooids small (3-6 mm) and round, transparent, uncolored or greenish, arising from a net of stolons. Body musculature pattern distinct for each species. Pharynx with four or five rows of stigmata and complete longitudinal vessels. Alimentary canal 

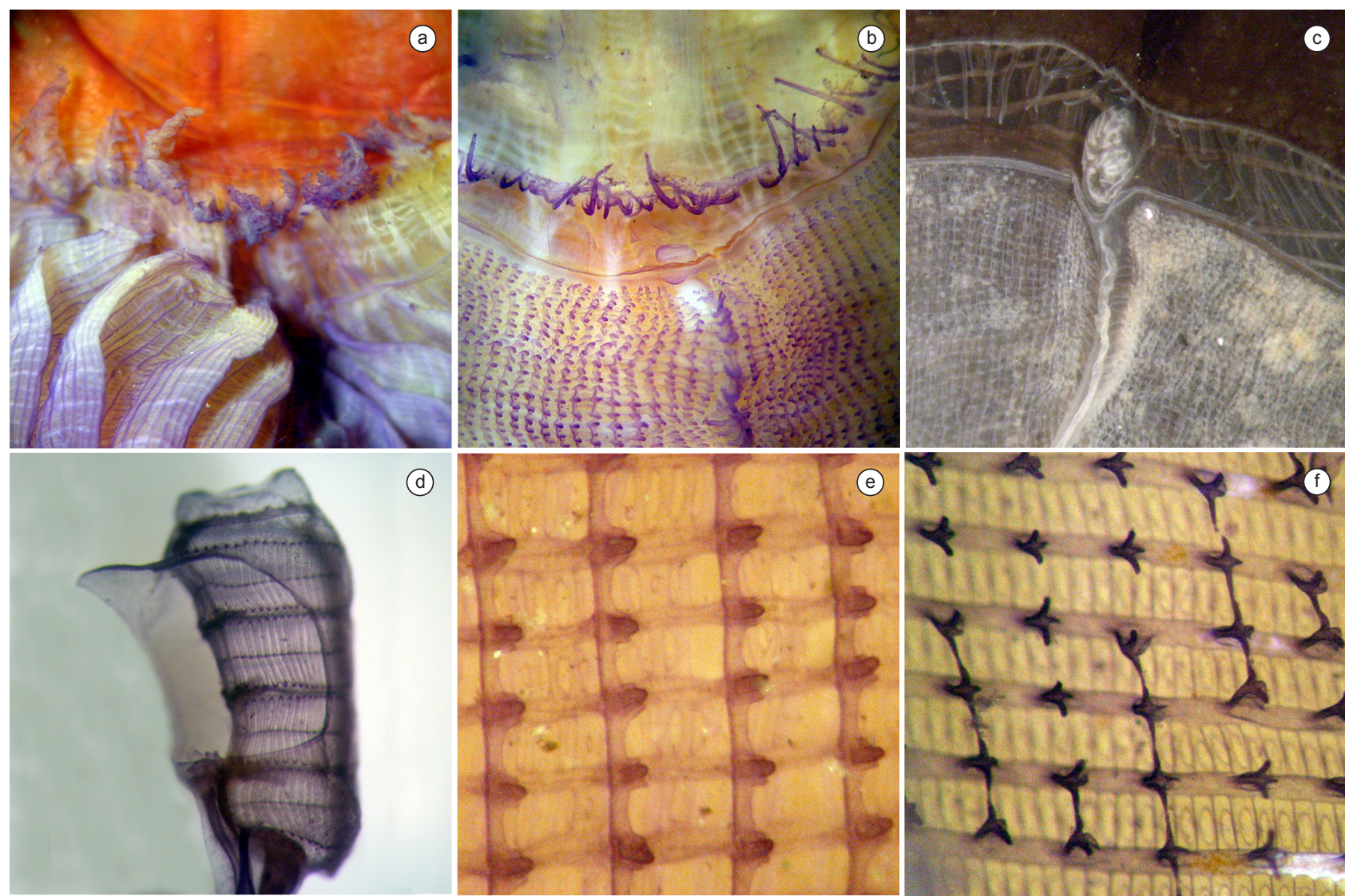

(d)
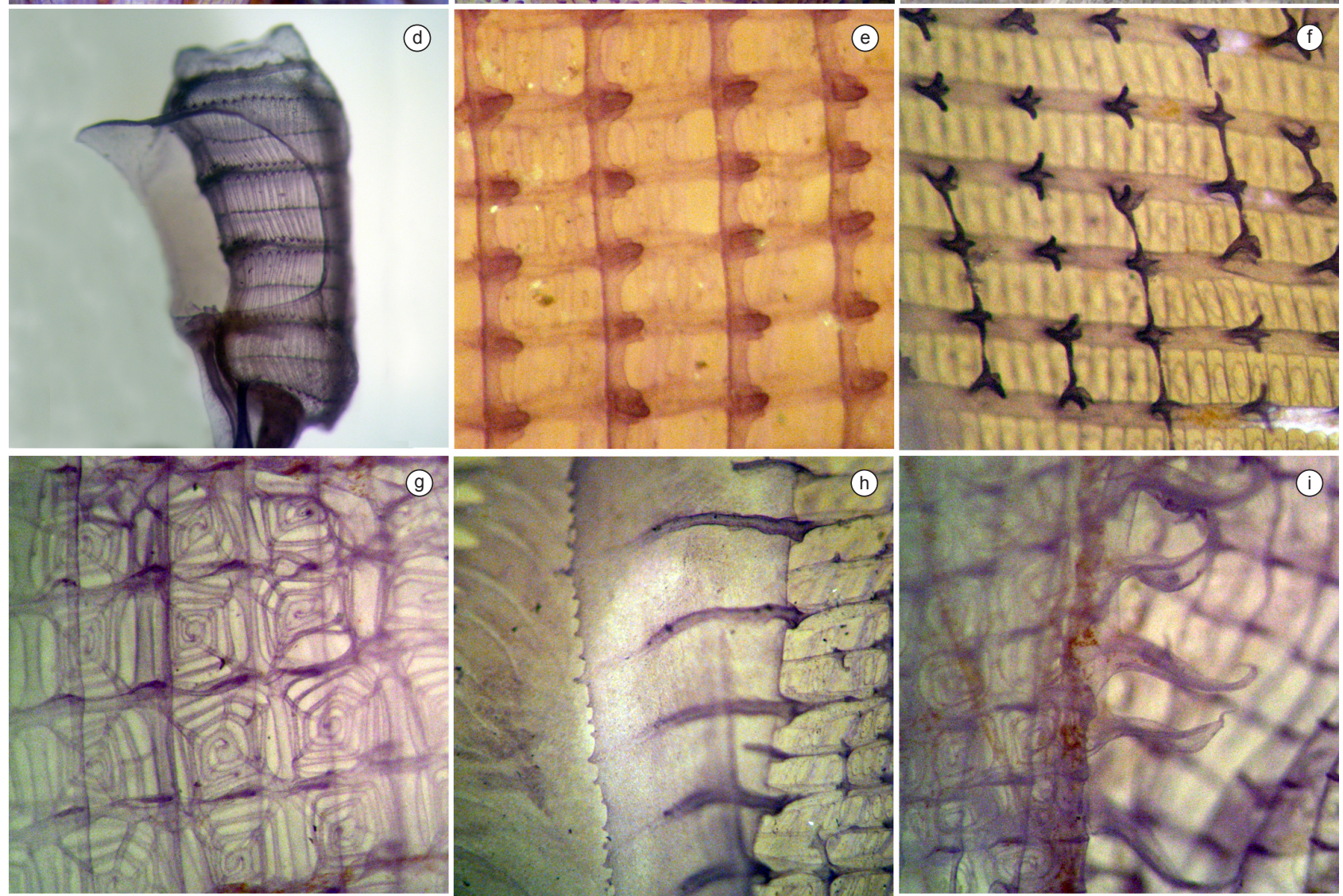

Figure 6. a) Herdmania pallida - ramified tentacles; b) Ciona intestinalis - simple tentacles and dorsal lamina divided in languets; c) Ascidia panamensis - simple tentacles and continuous dorsal lamina; d) Distaplia stylifera - pharynx (branchial basket) without longitudinal vessels; e) Ascidia interrupta - complete longitudinal vessels, papillae projecting into the pharynx lumen, straight stigmata; f) Rhodosoma turcicum -incomplete longitudinal vessels on supporting papillae; g) Corella minuta - papillae not projecting into the pharynx lumen, spiral stigmata; h) Ascidia interrupta - continuous dorsal lamina; i) Corella minuta - dorsal lamina subdivided in languets.

Figura 6. a) Herdmania pallida - tentáculos ramificados; b) Ciona intestinalis - tentáculos simples e lâmina dorsal dividida em linguetas; c) Ascidia panamensis - tentáculos simples e lâmina dorsal contínua; d) Distaplia stylifera - faringe (saco branquial) sem vasos longitudinais; e) Ascidia interrupta - vasos longitudinais completos, papilas projetando para dentro do lúmen da faringe, fendas retas; f) Rhodosoma turcicum - vasos longitudinais incompletos apoiados pelas papilas; g) Corella minuta - papilas não projetadas para dentro do lúmen da faringe, fendas espirais; h) Ascidia interrupta - lâmina dorsal contínua; i) Corella minuta - lâmina dorsal subdividida em linguetas.

almost horizontal underneath the pharynx; stomach wall smooth; rectum short. Gonads inside the intestinal loop. Larvae incubated inside the atrial cavity.

Perophora bermudensis Berrill, 1932: Bermuda, U.S. (Florida), Jamaica, Grand Cayman, Puerto Rico, Barbuda, Antiqua, St. Kitts, St. Croix, Belize, Aruba, Curaçao, Bonaire, Colombia, Aves Islands, Brazil (São Paulo).
Perophora carpenteria Goodbody, 1994: Jamaica, Belize.

Perophora listeri Wiegman, 1835: British Islands, Scotland, Senegal.

Perophora multiclathrata (Sluiter, 1904): Bermuda, Cuba, Jamaica, Puerto Rico, Guadeloupe, Martinique, Belize, Panama, Bonaire, Brazil (Alagoas, Espírito Santo, São Paulo to Santa Catarina), Senegal, Sierra Leone, Ghana. 

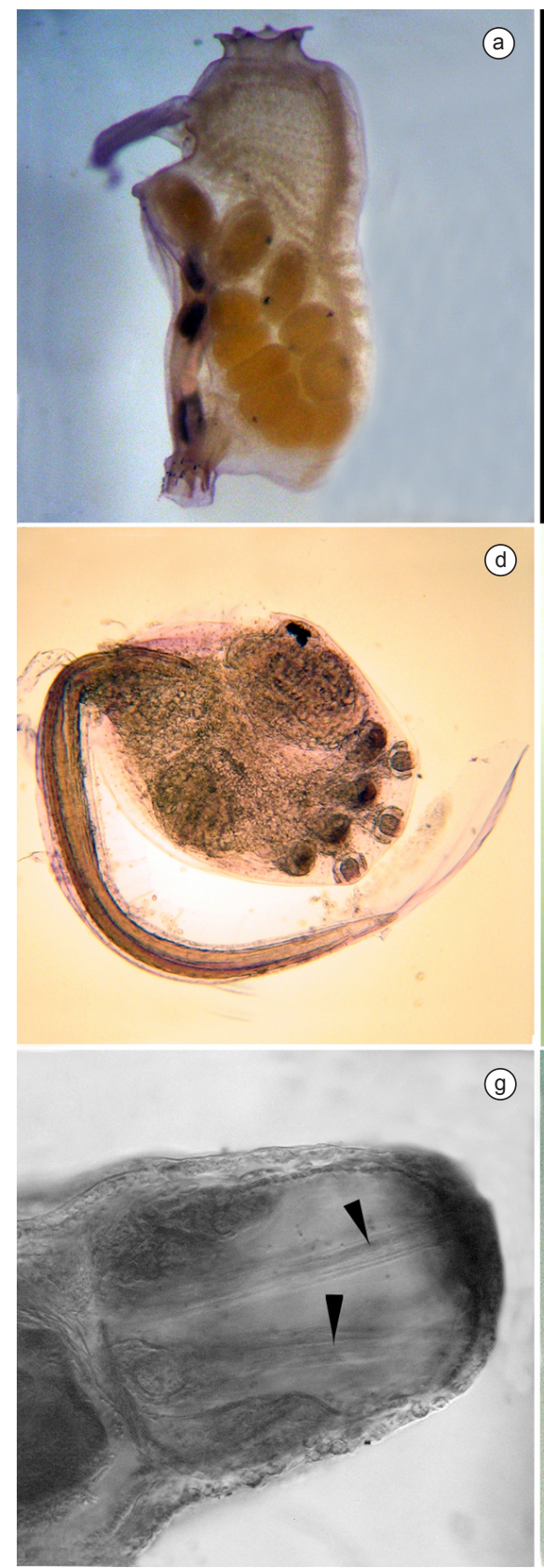
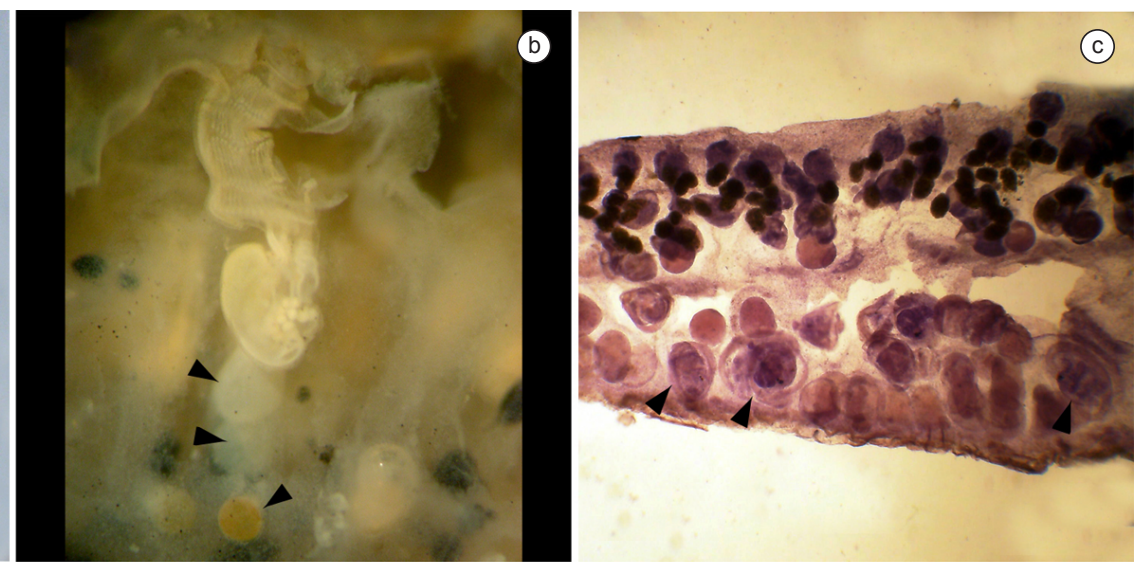

(e)
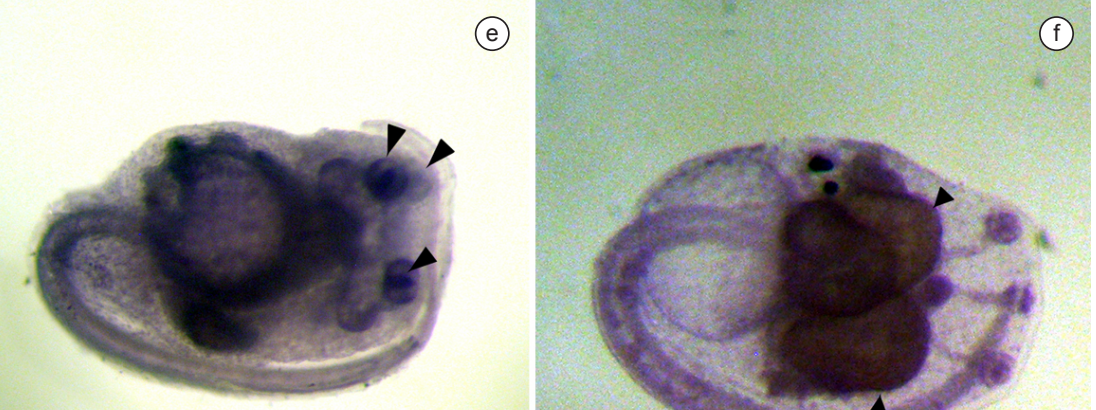

(
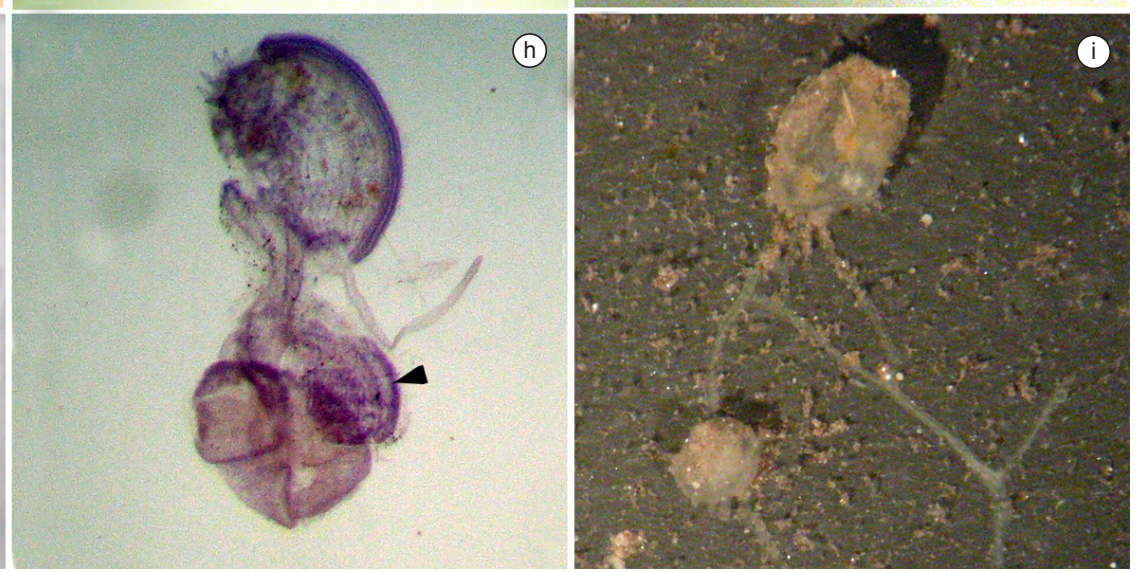

Figure 7. a) Polyclinum constellatum - brooding in the atrial cavity; b) Distaplia bermudensis - brooding in a pouch (arrowheads indicate embryos); c) Didemnum sp. - brooding in the tunic; d) Trididemnum orbiculatum - larva with adhesive papillae in line; e) Distaplia bermudensis - larva with adhesive papillae in triangle; f) Diplosoma listerianum - gemmiparous larva; g) Pycnoclavella aurilucens - larva with tubular invaginated adhesive papillae (photo by Rocio Perez-Portela); h) Diplosoma listerianum - budding from the esophageal neck (arrow indicate the new thorax); i) Ecteinascidia styeloides - budding from stolon.

Figura 7. a) Polyclinum constellatum - embriões e larvas incubados na cavidade atrial; b) Distaplia bermudensis - embriões incubados em uma bolsa; c) Didemnum sp. - embriões incubados na túnica; d) Trididemnum orbiculatum - larva com papilas adesivas em linha; e) Distaplia bermudensis - larva com papilas adesivas em triângulo; f) Diplosoma listerianum - larva gemípara; g) Pycnoclavella aurilucens - larva com papilas adesivas invaginadas e tubulares (foto por Rocio Perez-Portela); h) Diplosoma listerianum - brotamento no pedúnculo esofágico-retal (seta indica o novo tórax); i) Ecteinascidia styeloides - brotamento a partir de estolões.

Perophora regina Goodbody \& Cole, 1987: Belize, Brazil (Paraná, Santa Catarina).

Perophora viridis Verrill, 1871: Bermuda, U.S. (Maine to North Carolina), Jamaica, Puerto Rico, Guadeloupe, Belize, Panama, Bonaire, Guyana, Suriname, Brazil (Bahia to Santa Catarina), Azores, Sierra Leone.

\section{Ecteinascidia Herdman, 1880 (Figure 11b)}

Zooids elongate, transparent, uncolored or yellowish. Body musculature pattern distinct for each species. Pharynx with more than ten rows of stigmata. Alimentary canal with two loops or oblique; stomach wall with variable number of folds; long rectum. Gonads inside the intestinal loop. Larvae incubated inside the atrial cavity. 

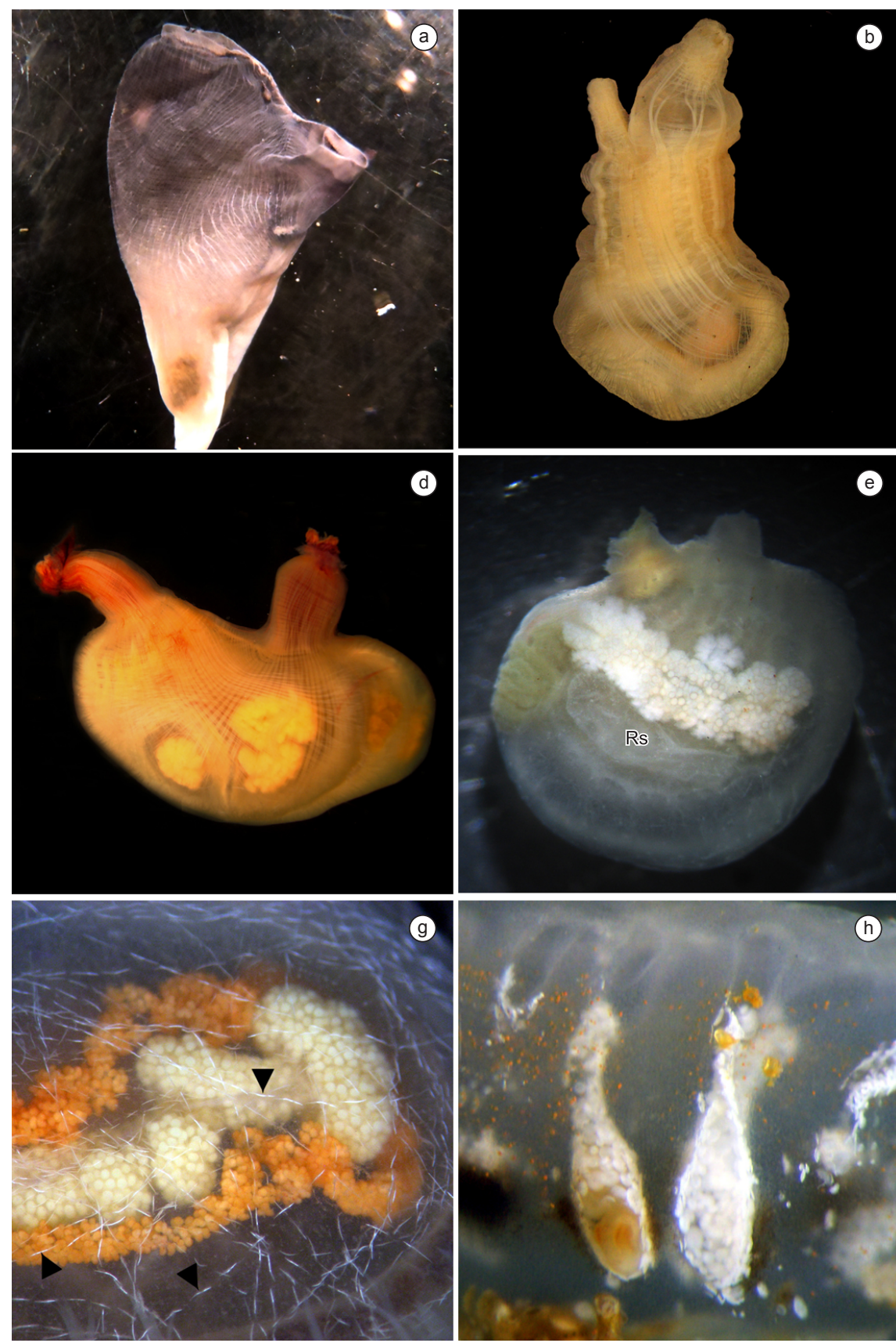
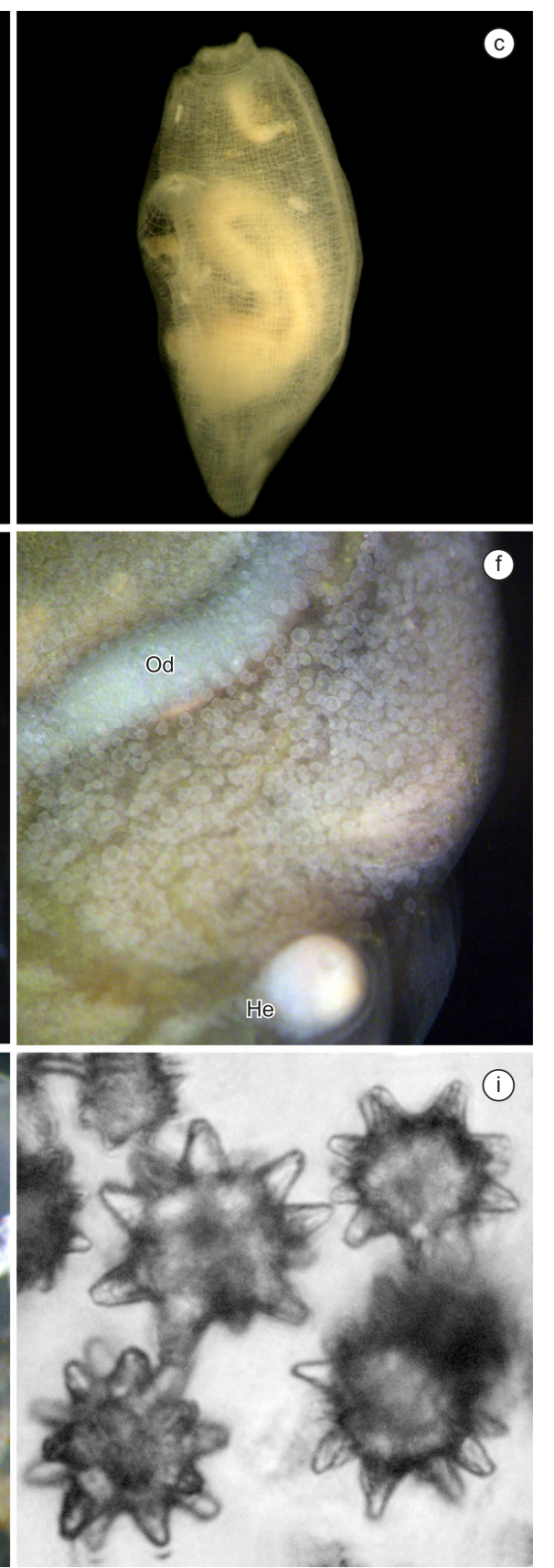

Figure 8. a) Rhopalaea abdominalis - thorax with thin oblique muscular fibers; b) Ciona intestinalis - thorax with wide longitudinal bands; c) Ascidia curvata-right side of the body with net of fibers in many directions; d) Microcosmus exasperatus - circular muscular fibers around siphons and longitudinal fibers spreading from the siphons posteriorly; e) Molgula phytophila - renal sac (Rs) (= kidney) on the right side of the body wall; f) Phallusia nigra - renal vesicles on the wall of the alimentary canal ( $\mathrm{Od}=$ oviduct, $\mathrm{He}=$ heart); g) Herdmania pallida - acicular spicules in the body wall; h) Cystodytes dellechiajei - disk-like spicules in a tunic spicular sac covering each zooid; i) Didemnid star-like spicules.

Figura 8. a) Rhopalaea abdominalis - tórax com finas fibras musculares oblíquas; b) Ciona intestinalis - tórax com faixas longitudinais largas; c) Ascidia curvata - lado direito do corpo com rede de fibras em muitas direções; d) Microcosmus exasperatus - fibras musculares circulares nos sifões e fibras longitudinais propagando-se posteriormente a partir dos sifões; e) Molgula phytophila - saco renal (Rs) (= rim) no lado direito do corpo; f) Phallusia nigra - vesículas renais na parede do trato digestivo ( $\mathrm{Od}=$ oviduto, He = coração); g) Herdmania pallida - espículas aciculares na parede do corpo; h) Cystodytes dellechiajei - espículas em forma de disco em um saco cobrindo cada zooide; i) Espículas estreladas de Didemnidae.

Ecteinascidia conklini Berrill, 1932: Bermuda, U.S. (Florida), Belize, Haiti, Puerto Rico, Barbuda, Guadeloupe, St. Martin, St. Croix, Saint Thomas, Curaçao, Bonaire, Brazil (Ceará, Pernambuco, Bahia)

Ecteinascidia minuta Berrill, 1932: Bermuda, U.S. (Florida), Cuba, Jamaica, St. Croix, Guadeloupe, Martinique, Belize,
Bonaire, Aruba, Brazil (Rio Grande do Norte, Espírito Santo), Trinidad and Tobago, Azores.

Ecteinascidia styeloides (Traustedt, 1882): Cuba, Jamaica, Guadeloupe, St. Croix, Belize, Panama, Venezuela, Brazil (Ceará). Ecteinascidia turbinata Herdman, 1880: Bermuda, U.S. (Florida), Bahamas, Jamaica, Cuba, Guadeloupe, St. Martin, St. 

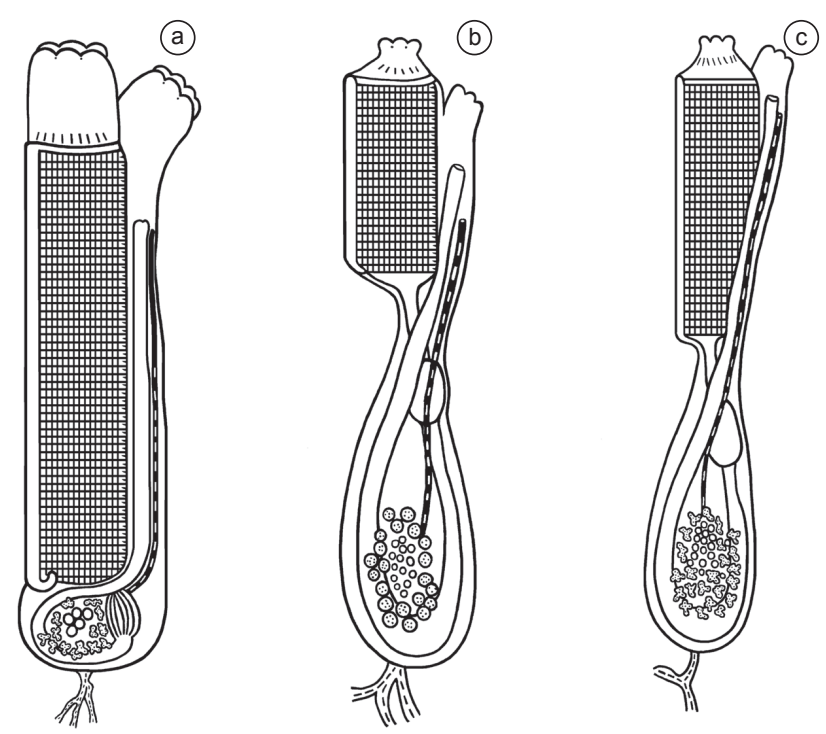

Figure 9. Cionidae \& Diazonidae. a) Ciona; b) Rhopalaea; c) Diazona Figura 9. Cionidae \& Diazonidae. a) Ciona; b) Rhopalaea; c) Diazona

Croix, Saint Thomas, Saint Vincent, Belize, Panama, Bonaire, Aruba, Curaçao, Guyana, Suriname, Brazil (Amapá to Maranhão, Bahia), Cape Verde, Senegal.

\section{Clavelinidae Forbes \& Hanley, 1848 (Table 6)}

Colonial ascidians with zooids connected by stolons or by a common basal tunic. Siphons smooth, both with independent apertures (Figure 1d). Abdomen long; stomach wall smooth with a typhlosole or with a few longitudinal folds. Large quantity of male follicles around the ovary. Large quantity of embryos and larvae brooded inside the atrial cavity.

\section{Clavelina Savigny, 1816 (Figure 12a)}

Zooids usually elongated and rather transparent tinted with blue, pink or white, usually forming pigmented lines along the endostyle and the peripharyngeal grove. Pharynx with eight to twenty rows of stigmata, without longitudinal vessels or folds. Body divided in thorax and abdomen, the latter elongated. Gonads present in the intestinal loop; fertilization occurs in the end of the expanded oviduct, forming an incubation pouch inside the atrial cavity where numerous larvae are brooded. Statocyte and ocellus always present in larvae. Budding occurs at terminal ampullae of the basal vascular stolons.

Clavelina brasiliensis (Millar, 1977): Suriname, Guyana, Brazil (Pará).

Clavelina lepadiformis (Müller, 1776): U.S. (Connecticut),

Norway, France, Ireland, Scotland, Morocco, Azores, South Africa.

Clavelina oblonga Herdman, 1880: Bermuda, U.S. (Georgia,

South Carolina, Florida), Cuba, Jamaica, Puerto Rico, Guadeloupe, Saint Thomas, Saint Vincent, Belize, Panama,

Table 6. Key for genera in Clavelinidae.

Tabela 6. Chave para gêneros em Clavelinidae.

\section{Number of rows of stigmata}

2. Adhesive papillae of larvae: I - invaginated into the anterior half of the larval trunk, long and tubular (Figure 7g); $\mathrm{P}$ - protruding, short and supported by on a frontal plate

\begin{tabular}{ccc}
\hline $\mathbf{1}$ & $\mathbf{2}$ & Genera \\
\hline $8-20$ & $\mathrm{P}$ & Clavelina \\
$3-8$ & $\mathrm{I}$ & Pycnoclavella \\
\hline
\end{tabular}
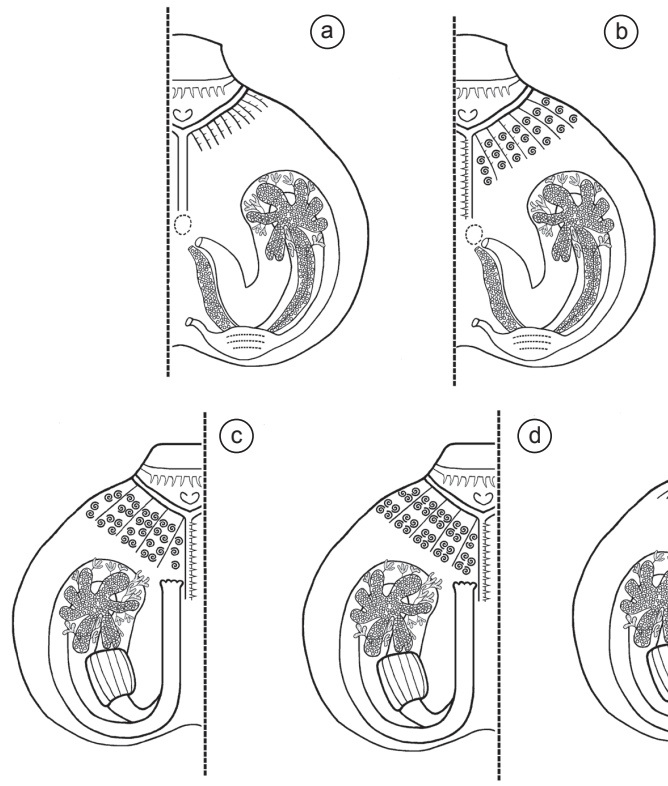

(d)

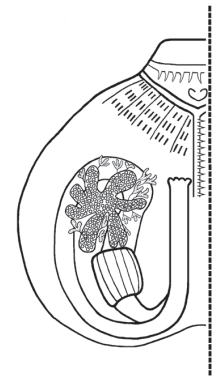

(e)

Figure 10. Ascidiidae, Agneziidae, Corellidae. a) Ascidia or Ascidiella or Phallusia; b) Agnezia; c) Chelyosoma; d) Corella; e) Rhodosoma.

Figura 10. Ascidiidae, Agneziidae, Corellidae. a) Ascidia ou Ascidiella ou Phallusia; b) Agnezia; c) Chelyosoma; d) Corella; e) Rhodosoma.

Aruba, Curaçao, Venezuela, Trinidad and Tobago, Brazil (Rio de Janeiro to Santa Catarina), Azores, Cape Verde Islands, Senegal. Clavelina picta (Verrill, 1900): Bermuda, U.S. (South Carolina,

Florida), Cuba, Jamaica, Puerto Rico, Belize, Venezuela. Clavelina puertosecensis Millar \& Goodbody, 1974: Jamaica, Guadeloupe, Belize, Panama.

Clavelina steenbrasensis Millar, 1955: South Africa.

Pycnoclavella Garstang, 1891 (Figure 12b)

Zooids smaller than in Clavelina, but also transparent and tinted with different colors. Pharynx with the first and the last row of stigmata usually bent or divided anteriorly or posteriorly respectively (Figure 15f). Body divided in thorax and abdomen, the latter elongated. A posterior stomach might be present (in P. minuta and P. belizeana). Replication of the zooids originating from horizontal division across the abdomen. Fertilization and development of the embryos inside the oviduct or in a brood chamber at the base of the atrial cavity. Larva with two or three long tubular adhesive organs (Figure 7g); some species without statocyte in the larva (P. aurilucens, P. communis and P. minuta).

Pycnoclavella atlantica Pérez-Portela et al. 2007: Spain

Pycnoclavella aurilucens Garstang, 1891: British Islands, Spain. Pycnoclavella belizeana Goodbody, 1996: Belize.

Pycnoclavella communis Pérez-Portela et al. 2007: Madeira

Island, Canary Islands, Strait of Gibraltar

Pycnoclavella minuta Millar, 1953: Ghana.

Pycnoclavella producta (Milne-Edwards, 1841): France, Spain.

Stomozoidae Kott, 1990

Colonial ascidians with globular massive colonies. Tunic cartilaginous and translucent. Siphons folded with six lobes, and projections along their margins (Figure 15a); both with independent apertures. Well developed velum in both siphons, projecting outside. Zooids are about $2.5 \mathrm{~cm}$ long, divided in thorax and abdomen with equal length. Thoracic longitudinal muscles form two ventral bands along the abdomen. Long stoloniferous vessels project from the 


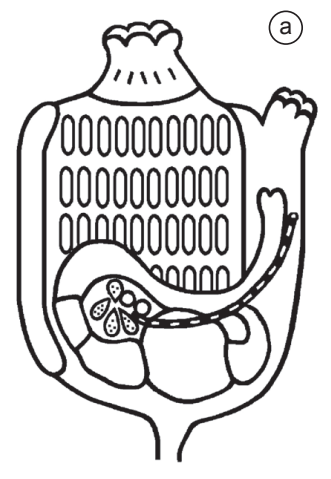

(b)

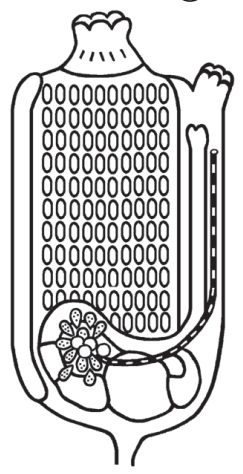

Figure 11. Perophoridae. a) Perophora; b) Ecteinascidia.

Figura 11. Perophoridae. a) Perophora; b) Ecteinascidia. (a)

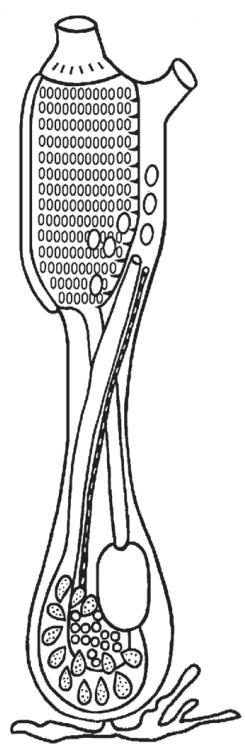

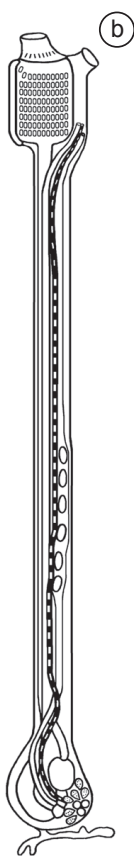

(b)

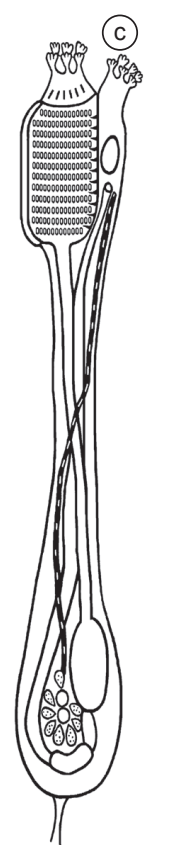

Figure 12. Clavelinidae \& Stomozoidae. a) Clavelina; b) Pycnoclavella; c) Stomozoa.

Figura 12. Clavelinidae \& Stomozoidae. a) Clavelina; b) Pycnoclavella; c) Stomozoa.

abdomen and ramify into the tunic. Ovary with only one or two oocytes.

\section{Stomozoa Kott, 1957 (Figure 12c)}

Stomozoa gigantea (Van Name, 1921): U.S. (Florida), Mexico, Guyana, Suriname, Brazil (Pará to Bahia), South Africa.

\section{Holozoidae Berrill, 1950 (Table 7)}

Colonial ascidians either pedunculated or sessile, in this case cushion-like, with zooid systems usually well organized around common cloacas. Oral siphon with six lobes; atrial siphon usually with a dorsal enlarged languet (Figure 5b). Pharynx with dorsal longitudinal muscular fibers that extend to the abdomen. The ascending intestine do not cross the esophagus. Gonads inside the intestinal loop or in a pouch linked to the abdomen by a thin peduncle;
Table 7. Key for genera in Holozoidae.

Tabela 7. Chave para gêneros em Holozoidae.

1. Pattern of systems of zooids: $L$ - Zooids organized in pairs along longitudinal lines on each side of the cloacal channels that might converge to a cloacal aperture in the apex of the colony; $\mathrm{O}$ - Circular, oval or elongate; more than one cloacal aperture per colony.

2. Parastigmatic vessels: $P$ - Present; 0 - Absent 3. Stomach wall: A - Areolate; $\mathrm{P}$ - Plicate; $\mathrm{S}$ - Smooth

\begin{tabular}{cccc}
\hline $\mathbf{1}$ & $\mathbf{2}$ & $\mathbf{3}$ & Genera \\
\hline $\mathrm{O}$ & $\mathrm{P}$ & $\mathrm{S}, \mathrm{P}, \mathrm{A}$ & Distaplia \\
$\mathrm{L}$ & 0 & $\mathrm{~S}$ & Sycozoa \\
\hline
\end{tabular}

ovary usually small with few oocytes $(<12)$. Larvae large (Figure 7e), sometimes with blastozooids. Embryos brooded in a pouch projecting from the thorax, sometimes broken loose inside the tunic (Figure 7b). One or two stoloniferous vessels projecting from the posterior part of the body, responsible for the budding process.

\section{Distaplia Della Valle, 1881 (Figure 13a)}

Colonies usually thick (4-20 mm), sometimes with many heads arising from a common base or short peduncles. Tunic with spongy texture. Different color morphs are common in some species. Zooids usually confined to the upper layer of tunic, organized around common cloaca. Zooids divided in thorax and abdomen with equal length. Thorax with long stigmata distributed in four rows, and crossed by parastigmatic vessels. Thoracic musculature formed by thin oblique fibers. The pyloric gland usually well developed. Stomach wall smooth or with ornamentation; intestine and rectum usually limited by a rectal valve (as in a Eudistoma represented in Figure 19b). Larvae incubated within a pouch inside the tunic; ocellus and statocyte present in the sensory vesicle of the larva; adhesive papillae supported by a common peduncle and disposed in triangle.

Distaplia bermudensis Van Name, 1902: Bermuda, U.S.

(North Carolina to Florida), Cuba, Jamaica, Puerto Rico, West Indies, Guadeloupe, Saint Thomas, Belize, Panama, Curaçao, Venezuela, Guyana, Suriname, Brazil (Pará, Ceará, Bahia to Santa Catarina), Senegal.

Distaplia capensis Michaelsen, 1934: South Africa, Vema Seamount.

Distaplia clavata (Sars, 1851): Greenland, Bay of Fundy,

Canada, U.S. (Maine, Massachusetts), Spitsbergen/Svalbard, Iceland e Norway.

Distaplia colligans Sluiter, 1932: South Georgia Islands.

Distaplia corolla Monniot, 1974: Guadeloupe, Panama, Azores.

Distaplia crassa Monniot, 1983c: Guadeloupe.

Distaplia cylindrica (Lesson, 1830): Strait of Magellan, South Georgia Islands, Antarctic.

Distaplia rosea Della Valle, 1881 : U.K., Scotland, English Channel.

Distaplia skoogi Michaelsen, 1934: South Africa.

Distaplia stylifera (Kowalevsky, 1874): U.S. (Florida), Jamaica, Curaçao, Panama, Colombia, Venezuela, Brazil (Ceará, Espírito Santo, São Paulo).

\section{Sycozoa Lesson, 1830 (Figure 13b)}

Cold water genus with ovate, clavate, or somewhat elongate stalked colonies. Zooids organized in pairs along longitudinal lines on each side of the cloacal channels that converge to a cloacal aperture in the apex of the colony. Zooids divided in thorax and abdomen with equal length. Thorax with long stigmata distributed in four rows, not 

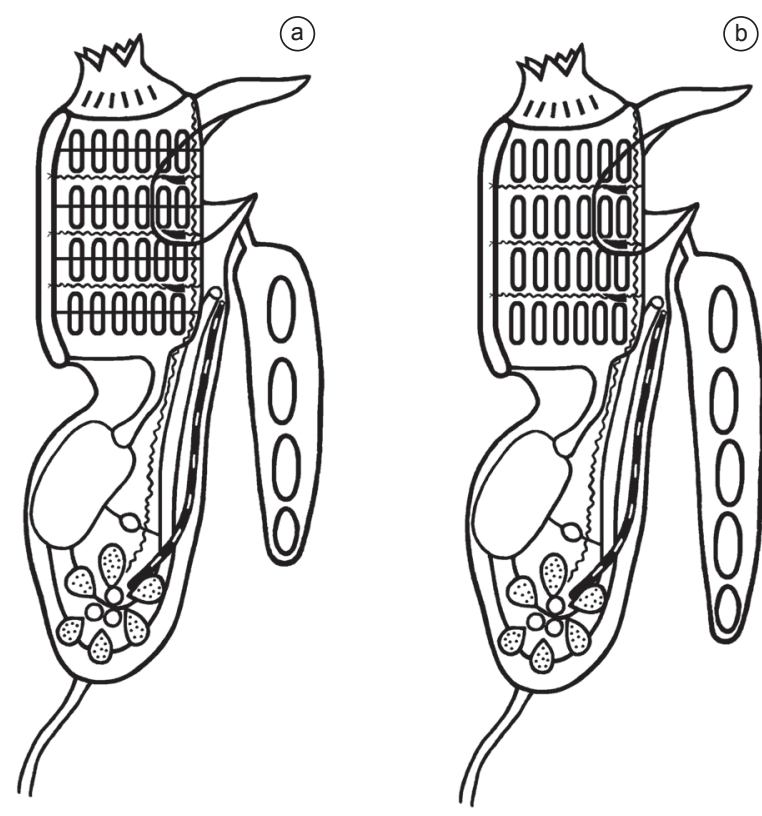

Figure 13. Holozoidae. a) Distaplia; b) Sycozoa.

Figura 13. Holozoidae. a) Distaplia; b) Sycozoa.

crossed by parastigmatic vessels. No more than five longitudinal muscular fibers on each side of the thorax. Gonads inside or slightly posterior to the intestinal loop, which can be twisted. Larva with large trunk $(>1 \mathrm{~mm})$, lacking ampullae and ocellus; they are incubated within long pouches inside the tunic.

Sycozoa gaimardi (Herdman, 1886): Strait of Magellan, Tierra del Fuego, Falkland Islands, South Shetland Islands, South Georgia Islands.

Sycozoa georgiana (Michaelsen, 1907): South Georgia Islands, South Sandwich Islands, South Shetland.

Sycozoa sigillinoides Lesson, 1830: Argentina, Strait of Magellan, Tierra del Fuego, Falkland Islands, South Georgia Islands, Antarctic.

Sycozoa umbellata (Michaelsen, 1898): Tierra del Fuego, South Georgia Islands.

\section{Didemnidae Giard, 1872 (Table 8)}

Colonial ascidians usually forming thin encrusting colonies. The consistency of the tunic varies as well as the presence and abundance of calcareous spicules (Figure 8i). Cloacal cavity and channels wide or reduced. Musculature restricted to the thorax. Lateral thoracic organs present in species with spicules. Presence of transverse muscular fibers between rows of stigmata in the pharynx and also dorsal longitudinal fibers that originate the muscular process that projects posteriorly into the tunic. Two to eight stolonic vessels projecting into the tunic, with an expanded end. Larvae usually well developed, sometimes gemmiparous with one or more blastozooids. Statocyte and ocellus always present.

\section{Trididemnum Della Valle, 1881 (Figure 14a)}

Colonies usually encrusting of variable size and thickness; sometimes forming hanging lobes. Some tropical species with symbiont algae. Spicules usually stellated and large $(\sim 100 \mu \mathrm{m})$, with few conical rays. Thorax short with three rows of stigmata and a tubular and posterior atrial siphon. Testis with only one follicle inside the intestinal loop, surrounded by the coils of the sperm duct.

Trididemnum cerebriforme Hartmeyer, 1913: Namibia, South Africa.
Table 8. Key for genera in Didemnidae

Tabela 8. Chave para gêneros em Didemnidae

1. Number of rows of stigmata in the zooid

2. Number of rows of stigmata in the oozooid (larva)

3. Atrial aperture: $\mathrm{W}-\mathrm{Wide} ; \mathrm{T}-$ Tubular

4. Sperm duct shape: $\mathrm{C}$ - Spiral (Figs. 14 a-d, 23a); S - Straight

(Figs. 14 e-f, 23b)

5. Spicules: $\mathrm{P}$ - Present; 0 - Absent

6. Number of male follicles

\begin{tabular}{ccccccc}
\hline $\mathbf{1}$ & $\mathbf{2}$ & $\mathbf{3}$ & $\mathbf{4}$ & $\mathbf{5}$ & $\mathbf{6}$ & Genera \\
\hline 3 & 3 & $\mathrm{~T}$ & $\mathrm{C}$ & $\mathrm{P}$ & 1 & Trididemnum \\
4 & 3 & $\mathrm{~W}$ & $\mathrm{C}$ & $\mathrm{P}$ & 1,2 & Didemnum \\
4 & 4 & $\mathrm{~W}$ & $\mathrm{C}$ & $\mathrm{P}$ & $>2$ & Polysyncraton \\
4 & 4 & $\mathrm{~T}$ & $\mathrm{C}$ & $\mathrm{P}$ & $1-\mathrm{n}$ & Leptoclinides \\
4 & 4 & $\mathrm{~W}$ & $\mathrm{~S}$ & $\mathrm{P}$ & $1-\mathrm{n}$ & Lissoclinum \\
4 & 4 & $\mathrm{~W}$ & $\mathrm{~S}$ & 0 & $1 *, 2,3 * *$ & Diplosoma \\
\hline *D. singulare, **D. tritestis & & & &
\end{tabular}

Trididemnum cereum (Giard, 1872): France, Spain, Senegal. Trididemnum cyanophorum Lafargue \& Duclaux, 1979: Belize, Puerto Rico, Guadeloupe.

Trididemnum delesseriae Lafargue, 1968: France, Spain.

Trididemnum hians Monniot, 1983a: Belize, Jamaica, Guadeloupe.

Trididemnum inarmatum (Drasche, 1883): Spain.

Trididemnum maragogi Rocha, 2002: Panama, Brazil (Alagoas).

Trididemnum meridionale Millar, 1953: Ghana.

Trididemnum orbiculatum (Van Name, 1902): Bermuda, U.S.

(Florida), Cuba, West Indies, Guadeloupe, Belize, Panama,

Curaçao, Venezuela, Brazil (Ceará, Bahia to Santa Catarina).

Trididemnum palmae Monniot, 1984: Guadeloupe.

Trididemnum savignii (Herdman, 1886): Bermuda, U.S. (South

Carolina), Cuba, Guadeloupe, Panama, Senegal.

Trididemnum solidum (Van Name, 1902): Bermuda, U.S. (Florida), Bahamas, Belize, Cuba, Jamaica, Puerto Rico, West Indies, Guadeloupe, Saint Thomas, Curaçao, Brazil (Rio Grande do Norte).

Trididemnum tenerum (Verrill, 1871): U.S. (Maine, Massachusetts), Greenland, Iceland, Spitsbergen/Svalbard, Faroe Islands, Norway, Skagerrak Strait, U.K., Scotland.

Trididemnum translucidum (Lafargue, 1968): France.

Didemnum Savigny, 1816 (Figure 14b)

Encrusting colonies variable in color and size, sometimes forming lobes. Spicules variable in number, shape and size (usually less than $50 \mu \mathrm{m})$. Zooids usually smaller than in Trididemnum $(1 \mathrm{~mm}$ long or less). A few species with an atrial languet. Pharynx with four rows of stigmata, rarely with more than eight stigmata per half row. Most species with one male follicle, surrounded by the coils of the sperm duct. Larval trunk usually smaller than $0,5 \mathrm{~mm}$, occasionally gemmiparous. A few species with two adhesive papillae instead of three; variable number of ectodermal ampullae.

Didemnum ahu Monniot \& Monniot, 1987: Brazil (Pernambuco,

Bahia, São Paulo, Santa Catarina).

Didemnum albidum (Verrill, 1871): Greenland, Davis Strait, U.S. (Maine, Massachusetts), Spitsbergen/Svalbard, Jan Mayen Islands, Iceland, Faroe Islands, Norway, Sweden, Scotland.

Didemnum apersum Tokioka, 1953: Brazil (Bahia, São Paulo). Didemnum biglans (Sluiter, 1906): South Shetland Islands. 

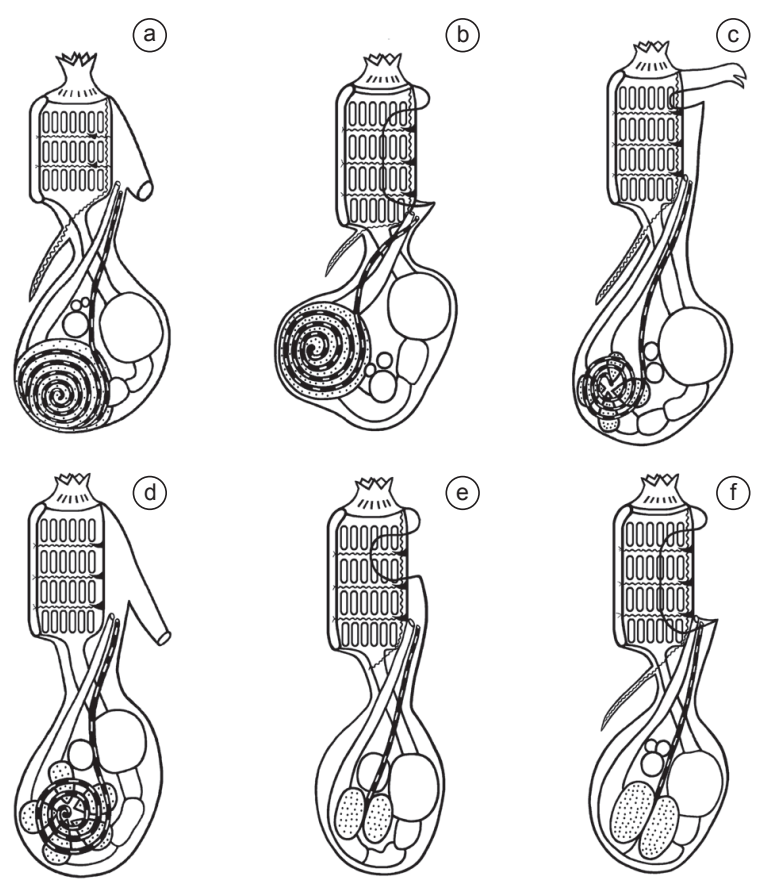

Figure 14. Didemnidae. a) Trididemnum; b) Didemnum; c) Polysyncraton; d) Leptoclinides; e) Lissoclinum; f) Diplosoma.

Figura 14. Didemnidae. a) Trididemnum; b) Didemnum; c) Polysyncraton; d) Leptoclinides; e) Lissoclinum; f) Diplosoma.

Didemnum calliginosum Monniot, 1984: Guadeloupe, Panamá, Brazil (Santa Catarina).

Didemnum cineraceum (Sluiter, 1898a): Belize, Jamaica, Guadeloupe, Panama, Venezuela, Brazil (Ceará, São Paulo), Sierra Leone.

Didemnum conchyliatum (Sluiter, 1898a): Jamaica, Guadeloupe, St. Lucia, Grenada, Belize, Panama, Curaçao, Venezuela.

Didemnum coriaceum (Drasche, 1883): France, Spain, Portugal.

Didemnum duplicatum Monniot, 1983a: Guadeloupe, Panama, Venezuela.

Didemnum galacteum Lotufo \& Dias, 2007: Brazil (Ceará to Paraná)

Didemnum granulatum Tokioka, 1954: Panama, Brazil (Ceará

to Santa Catarina), Senegal.

Didemnum halimedae Monniot, 1983a: Jamaica, Guadeloupe. Didemnum inauratum Monniot, 1983a: Belize, Guadeloupe.

Didemnum lahillei Hartmeyer, 1909: France, Spain, Portugal,

Azores islands, Senegal.

Didemnum ligulum Monniot, 1983a: Guadeloupe, Brazil

(Ceará to Santa Catarina)

Didemnum lutarium (Van Name, 1910): U.S. (Maine to Massachusetts).

Didemnum maculosum (Milne-Edwards, 1841): Faroe Islands, Norway, Skagerrak Strait, Germany, U.K., English Channel, France, Spain, Azores, Senegal.

Didemnum obscurum Monniot, 1969: Senegal.

Didemnum perlucidum Monniot, 1983a: U.S. (Florida, Gulf of Mexico, Texas), Guadeloupe, Belize, Panama, Venezuela, Brazil (Ceará, Bahia to Santa Catarina), Senegal.

Didemnum protectum (Daumezon, 1908): France.
Didemnum psammatodes (Sluiter, 1895): Cuba, Jamaica, Guadeloupe, Saint Vincent, Grenada, St. Lucia, Belize, Panama, Aruba, Curaçao, Brazil (Ceará to São Paulo), Sierra Leone.

Didemnum pseudofulgens Medioni, 1970: Spain.

Didemnum rodriguesi Rocha \& Monniot, 1993: Brazil (Rio de Janeiro to Santa Catarina).

Didemnum speciosum (Herdman, 1886): Bermudas, U.S. (Maine to Florida), Bahamas, Cuba, Jamaica, Puerto Rico, Saint Thomas, Mexico, Panama, Curaçao, Brazil (Amapá to Santa Catarina).

Didemnum stilense Michaelsen, 1934: South Africa.

Didemnum studeri Hartmeyer, 1911: Argentina, Antarctic.

Didemnum tenue (Herdman, 1886): Argentina, South Georgia Islands.

Didemnum tetrahedrum Dias \& Rodrigues, 2004: Brazil (São Paulo).

Didemnum vanderhorsti Van Name, 1924: U.S. (Florida), Jamaica, Curaçao, Venezuela, Brazil (Ceará, Pernambuco to Santa Catarina).

Didemnum vexillum Kott, 2002: U.S. (Maine to Connecticut).

\section{Polysyncratron Nott, 1892 (Figure 14c)}

Encrusting colonies variable in color and size. Spicules usually stellated and large $(\sim 100 \mu \mathrm{m})$. Zooids very similar to the ones in Didemnum, but usually with an atrial languet and pharynx with more than nine stigmata in each half row. Testis with two or more follicles surrounded by 3-5 separated coils of the sperm duct (Figure 23a). Larvae usually gemmiparous and large (0,7-1 mm trunk length).

Polysyncraton amethysteum (Van Name, 1902): Bermuda,

U.S. (Florida), Cuba, Puerto Rico, Belize, Colombia, Brazil ?

(Pernambuco to Santa Catarina), Cape Verde, Senegal, Ghana.

Polysyncraton bilobatum Lafargue, 1968: France, Senegal, Namibia.

Polysyncraton canetense (Brement, 1913): Azores.

Polysyncraton lacazei (Giard, 1872): France, Spain, Senegal.

Polysyncraton louminae Monniot, 1984: Guadeloupe.

Polysyncraton reedi Monniot \& Monniot, 1994a: Senegal.

Polysyncraton trivolutum (Millar, 1960a): Magellan region,

Falkland Islands, South Shetland Islands.

\section{Leptoclinides Bjerkan, 1905 (Figure 14d)}

Encrusting colonies variable in color and size. Thorax of zooids very similar to the ones in Trididemnum, but with four rows of stigmata. Testis with one or more follicles surrounded by few and separated coils of the sperm duct as in Polysyncraton. Larvae never gemmiparous.

Leptoclinides brasiliensis Michaelsen, 1923: Brazil (Bahia). Leptoclinides faeröensis Bjerkan, 1905: U.S., Davis Strait, Canada, Spitsbergen/Svalbard, Iceland, Faroe Islands, Norway, Denmark, U.K., English Channel.

Leptoclinides latus Monniot, 1983a: Guadeloupe, Brazil (Santa Catarina).

Leptoclinides torosus Monniot, 1983a: Guadeloupe.

\section{Lissoclinum Verrill, 1871 (Figure 14e)}

Colonies encrusting and thin, with variable number of spicules. Zooids usually with a large and delicate thorax, with the wide atrial aperture exposing part of the pharynx. Atrial languet usually present and not bifurcate. Testis with variable number of male follicles, but usually one or two; straight sperm duct. Larvae sometimes gemmiparous.

Lissoclinum abdominale Monniot, 1983a: Jamaica, Guadeloupe, Belize, Panama. 


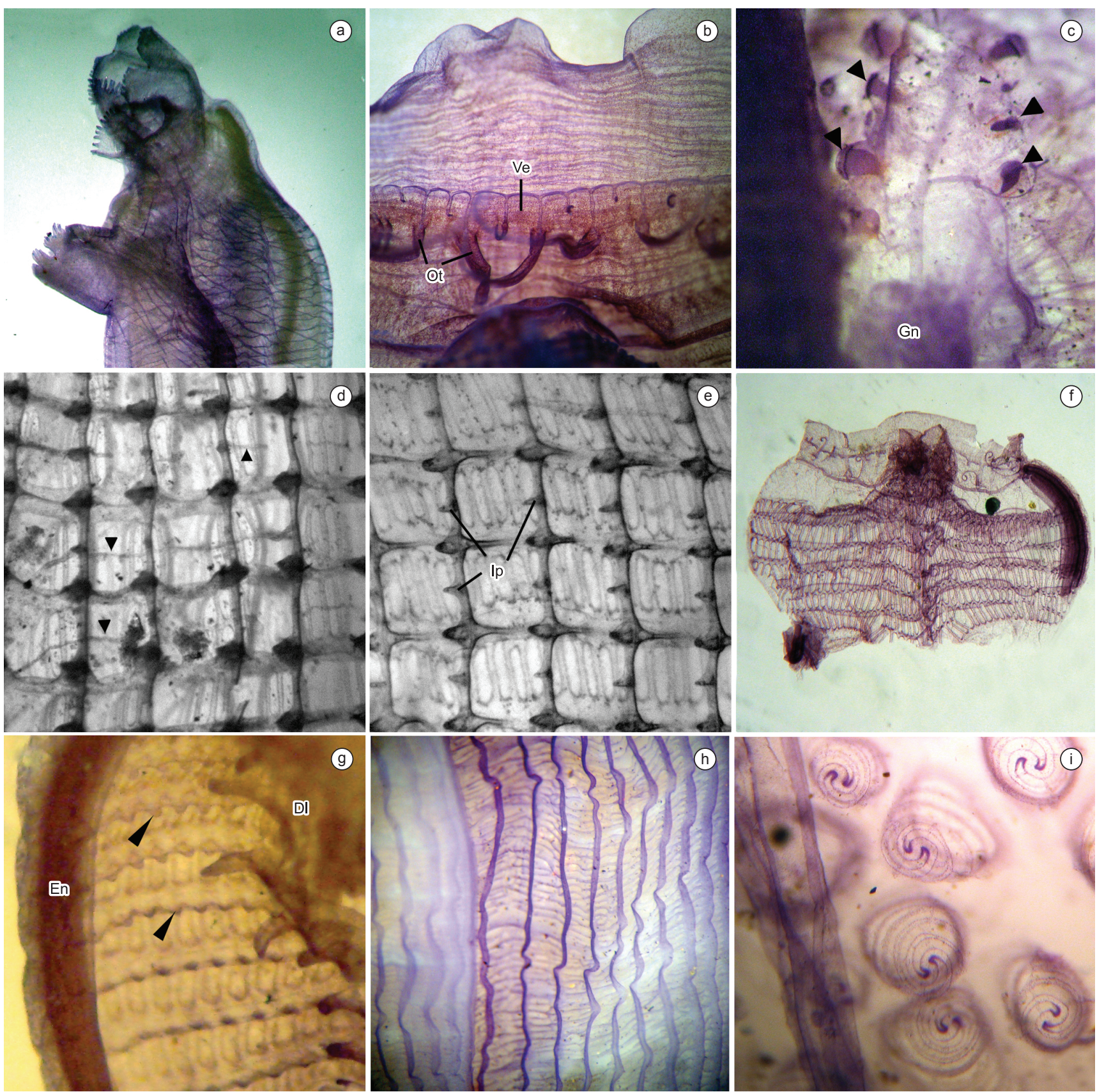

Figure 15. a) Stomozoa gigantea - folded and complex siphon lobes; b) Rhopalaea abdominalis - velum (Ve) anterior to the oral tentacles (Ot); c) Phallusia nigra - accessory openings along the neural duct (arrows; Gn = neural gland); d) Ascidia sp. - parastigmatic vessels; e) Ascidia archaia - intermediate papillae (Ip); f) Pycnoclavella communis - pharynx with the first row of stigmata bent anteriorly (photo by Rocio PérezPortela); g) Polyclinum constellatum - papillated transverse vessels (En = endostyle, $\mathrm{Dl}$ = dorsal lamina); h) Boltenia ovifera - pharynx with transverse stigmata; i) Bostrichobranchus digonas - infundibulae irregularly arranged.

Figura 15. a) Stomozoa gigantea - lobos dos sifões dobrados e ramificados; b) Rhopalaea abdominalis - velum (Ve) anterior aos tentáculos orais (Ot); c) Phallusia nigra - aberturas acessórias ao longo do duto neural (setas; $\mathrm{Gn}$ = glândula neural); d) Ascidia sp. - vasos parastigmáticos; e) Ascidia archaia - papilas intermediárias (Ip); f) Pycnoclavella communis - faringe com a primeira linha de fendas curvada anteriormente (foto de Rocio Pérez-Portela); g) Polyclinum constellatum - vasos transversais com papilas ( $\mathrm{En}=$ endóstilo, $\mathrm{Dl}=$ lâmina dorsal); $\mathrm{h}$ ) Boltenia ovifera - faringe com fendas transversais; i) Bostrichobranchus digonas - infundíbulos arranjados irregularmente.

Lissoclinum aureum Verrill 1871: Canada, U.S. (Maine, Massachusetts), Spitsbergen/Svalbard, Iceland.

Lissoclinum branchiatus (Buge \& Monniot, 1972): France. Lissoclinum cavum Millar, 1962: Namibia.

Lissoclinum fragile (Van Name, 1902): Bermuda, U.S. (Florida), Dominican Republic, Jamaica, Guadeloupe, Belize, Panama,
Curaçao, Venezuela, Brazil (Ceará, Pernambuco, Rio de Janeiro to Santa Catarina), Azores, Sierra Leone, Argentina (Patagonia). Lissoclinum marpum Millar, 1953: Ghana, Vema Seamount.

Lissoclinum perforatum (Giard, 1872): Guadeloupe, Brazil (Rio Grande do Norte, Rio de Janeiro to Santa Catarina), Scotland, U.K., France, Spain, Portugal, Azores. 
Lissoclinum verrilli (Van Name, 1902): Bermuda, U.S. (Florida), Cuba, Guadeloupe, Belize, Panama, Ghana, Brazil (Santa Catarina)

Lissoclinum weigelei Lafargue, 1968: France, Spain.

\section{Diplosoma MacDonald, 1859 (Figure 14f)}

Colonies encrusting and usually very soft with with gelatinous or mucous tunic. Similar to Lissoclinum but without spicules. Thorax long and delicate with a large part of the pharynx exposed. Testis usually with two follicles; straight sperm duct. Larvae gemmiparous (Figure 7f).

Diplosoma glandulosum Monniot, 1983a: Jamaica, Belize, Guadeloupe.

Diplosoma lafargueae Vazquez, 1993: Spain.

Diplosoma listerianum (Milne-Edwards, 1841): Bermuda, U.S. (South Carolina, Florida), Belize, Jamaica, Puerto Rico, Guadeloupe, Saint Thomas, Aruba, Curaçao, Bonaire, Panama, Venezuela, Guyana, Suriname, Brazil (Rio Grande do Norte to Santa Catarina), Norway, Germany, Shetland Islands, Scotland, U.K., Ireland, English Channel, France, Spain, Portugal, Azores, Morocco, Senegal, Ghana, Namibia, South Africa.

Diplosoma longinquum (Sluiter, 1912): Falkland Islands, Argentina (Patagonia).

Diplosoma singulare Lafargue, 1968: France.

Diplosoma spongiforme (Giard, 1872): France, Spain, Senegal,

Brazil ? (Paraná)

Diplosoma tritestis Monniot, 1984: Guadeloupe.

Diplosoma virens (Hartmeyer, 1909): Belize.

\section{Polycitoridae Michaelsen, 1904 (Table 9)}

Colonial ascidians with cushion-like or massive colonies, sometimes with a peduncle. Both siphons with independent apertures, sometimes forming round systems with the atrial apertures in the center of the system (Figure 1b). Zooids completely or partially embedded in the tunic. Abdomen usually long with a small stolonic vessel. Body wall musculature strong, causing contraction of not well relaxed zooids; both transverse and longitudinal fibers on the thorax; longitudinal fibers form two bands along the ventral side of the abdomen. Gonads might be just posterior to the intestinal loop, forming a pseudo post-abdomen, which does not contain the heart (eg. Eudistoma recifensis and E. vitreum).

\section{Cystodytes Drasche, 1883 (Figure 16a)}

Colonial ascidians with zooids completely embedded and usually arranged in circles. Colonies form thick cushions with smooth surface. Zooids very short and usually contracted. Thorax with four rows of stigmata and abdomen covered by disk-like calcareous spicules (Figure $8 \mathrm{~h}$ ). Ovary with only one oocyte. Larva with many ampullae, sometimes forming a crown around the three or more adhesive papillae; four rows of stigmata in the oozooid. Brooding in the atrial cavity or in an abdominal pouch.

Cystodytes antarcticus Sluiter, 1912: South Shetland Island. Cystodytes dellechiajei (Della Valle, 1877): Bermuda, U.S. (Florida), Cuba, Guadeloupe, Belize, Panama, Guyana, Suriname, Brazil (Pará to Santa Catarina), Spain, Portugal, Azores, Mauritania, Senegal, Ghana, Cameroon, South Africa. Cystodytes denudatus Pérès, 1953: Senegal.

Cystodytes guinensis Michaelsen, 1914: Azores, Morocco, Senegal, Cape Verde, Ghana.

Cystodytes roseolus Hartmeyer, 1912: Senegal, South Africa. Cystodytes senegalense Monniot, 1969: Senegal.

\section{Eudistoma Caullery, 1909 (Figure 16b)}

Cushion or mushroom-like colonies, sometimes forming lobes. Tunic frequently with sand, shell fragments and algae inside. Zooids
Table 9. Key for genera in Polycitoridae.

Tabela 9. Chave para gêneros em Polycitoridae.

1. Colony structure: E - Zooids completely embedded in a common tunic; P - Zooids partially embedded

2. Presence of spicules inside the tunic: $\mathrm{P}$ - Present (Figure 8h); 0 - Absent

3. Number of rows of stigmata

4. Stomach wall: $\mathrm{P}$ - Plicate; $\mathrm{S}$ - Smooth

\begin{tabular}{ccccc}
\hline $\mathbf{1}$ & $\mathbf{2}$ & $\mathbf{3}$ & $\mathbf{4}$ & Genera \\
\hline $\mathrm{E}$ & $\mathrm{P}$ & 4 & $\mathrm{~S}$ & Cystodytes \\
$\mathrm{E}$ & $0, \mathrm{P}^{*}$ & 3 & $\mathrm{~S}$ & Eudistoma \\
$\mathrm{P}$ & 0 & 3 & $\mathrm{~S}$ & Archidistoma \\
$\mathrm{E}$ & 0 & $4-20$ & $\mathrm{P}, \mathrm{S}$ & Polycitor \\
\hline
\end{tabular}

*Present in Eudistoma spiculiferum Millar, 1977.
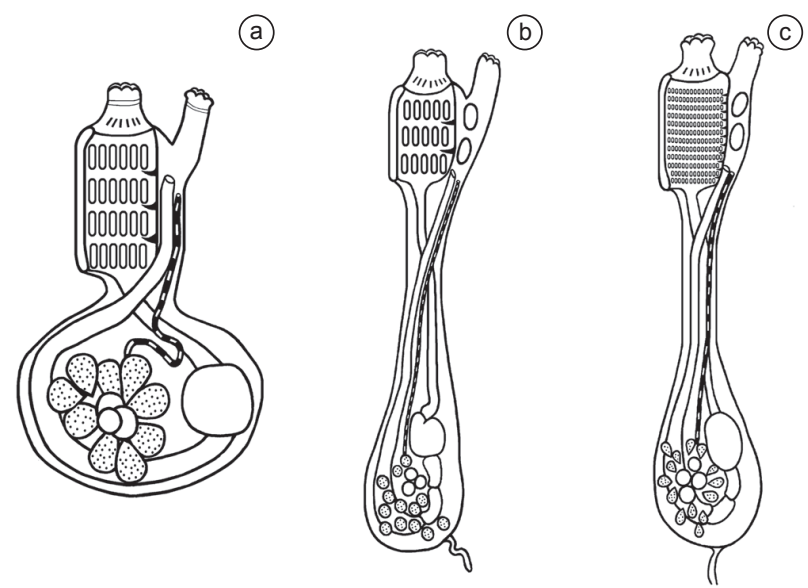

Figure 16. Polycitoridae. a) Cystodytes; b) Eudistoma or Archidistoma; c) Polycitor.

Figura 16. Polycitoridae. a) Cystodytes; b) Eudistoma ou Archidistoma; c) Polycitor.

usually organized in systems, in this case the atrial siphon is long and the apertures lay in the center of the system (Figure 1b). Thorax short with three rows of stigmata and usually covered by strong musculature. Abdomen long with a small and smooth stomach. Pyloric gland well developed on the rectum wall, with distinctive patterns differentiating species (Figure 19b). Ovary with many oocytes of different sizes. Brooding in the atrial cavity.

Eudistoma accrum Millar, 1953: Senegal, Ghana.

Eudistoma almadiense Pérès, 1953: Senegal.

Eudistoma angolanum (Michaelsen, 1915): Azores, Senegal,

Sierra Leone, Ghana, Togo, Angola.

Eudistoma capsulatum (Van Name, 1902): Bermuda, U.S.

(Virginia to Florida), Bahamas, Mexico, Belize, Cuba, Dominican Republic, Guadeloupe, Cape Verde.

Eudistoma carolinense Van Name, 1945: U.S. (South Carolina,

Florida), Guadeloupe, Martinique, Panama, Brazil (Alagoas to Espírito Santo, Paraná, Santa Catarina).

Eudistoma clarum (Van Name, 1902): Bermuda, Belize, Guadeloupe, Panama, Bonaire, Azores, Senegal.

Eudistoma clavatum Rocha \& Bonnet, 2009: Brasil (São Paulo, Santa Catarina).

Eudistoma hepaticum (Van Name, 1921): U.S. (Florida), Mexico, Jamaica, Guadeloupe, Saint Thomas.

Eudistoma ifani Monniot, 1969: Senegal. 
Eudistoma illotum (Sluiter, 1898b): South Africa.

Eudistoma obscuratum (Van Name, 1902): Bermuda, U.S. (Florida), Belize, Panama.

Eudistoma olivaceum (Van Name, 1902): U.S. (South Carolina, Florida), Bahamas, Small Cayman, Cuba, Jamaica, Puerto Rico, Guadeloupe, St. Croix, St. Martin, Grenada, Belize, Panama, Curaçao, Bonaire.

Eudistoma paesslerioides (Michaelsen, 1914): Senegal.

Eudistoma planum Pérès, 1948: Senegal.

Eudistoma platense Van Name, 1945: Argentina.

Eudistoma ramosum Millar, 1953: Senegal, Sierra Leone, Ghana.

Eudistoma recifense Millar, 1977: Brazil (Ceará, Pernambuco). Eudistoma renieri (Hartmeyer, 1912): South Africa.

Eudistoma repens Millar, 1977: Brazil (Amapá, Maranhão). Eudistoma roseum Vazquez \& Ramos-Espla, 1993a: Spain.

Eudistoma saldanhai Millar, 1977: Guyana, Suriname, Brazil (Pará to Alagoas).

Eudistoma spiculiferum Millar, 1977: Brazil (Pará).

Eudistoma surinamense Millar, 1978: Guyana, Suriname.

Eudistoma tarponense Van Name, 1945: U.S. (Florida).

Eudistoma vannamei Millar, 1977: Brazil (Amapá to Bahia).

Eudistoma vitreum (Sars, 1851): Canada (Newfoundland).

Archidistoma Garstang, 1891 (Figure 16b)

Colonial ascidians, encrusting, with zooids connected only by the posterior region, sometimes organized in clumps. Zooids very similar to Eudistoma in structure. Brooding in the atrial cavity

Archidistoma aggregatum Garstang, 1891: U.S. (North

Carolina), U.K.

Polycitor Renier, 1804 (Figure 16c)

Colonial ascidians either with a peduncle or not, in this case cushion-like or spherical. Zooids elongated with $4-20$ rows of stigmata in the pharynx and a long abdomen with smooth or folded wall stomach. Brooding inside the atrial cavity or inside a pouch (as in $P$. searli).

Polycitor crystallinus (Renier, 1804): Senegal, Gambia.

Polycitor lüderitzi Michaelsen 1915: Senegal, Sierra Leone.

Polycitor magalhaensis (Michaelsen, 1907): Strait of Magellan.

Polycitor searli Kott, 1952: U.K.

Polyclinidae Milne Edwards, 1842 (Table 10)

Colonial ascidians with cushion-like or massive colonies, sometimes with a peduncle. Zooids completely embedded in the tunic forming systems around a common cloaca. Oral siphon with 6-8 lobes, but atrial aperture smooth with or without a dorsal languet. Post-abdomen largely connected to the abdomen (Figures 3b, 5c) or connected by a thin peduncle. Body wall musculature formed by longitudinal fibers restricted to the thorax or extending to the end of the post-abdomen. Transverse pharyngeal vessels might present muscular fibers. Ovary small and anterior to the numerous male follicles in the post-abdomen.

\section{Polyclinum Savigny, 1816 (Figure 17a)}

Colonies with gelatinous tunic sometimes with sand, cushion-like or rounded. Elongated zooids with a large atrial languet (Figure 7a); thorax larger than abdomen. Longitudinal musculature restricted to the thorax. Pharynx with $10-20$ rows of stigmata; transverse muscle fibers between them. Abdomen in a more or less $90^{\circ}$ position in relation to the thorax. Post-abdomen sac-like with the ovary surrounded by male follicles. Larval trunk no longer than $0.6 \mathrm{~mm}$; ectodermic vesicles usually present. Brooding inside the atrial cavity
Table 10. Key for genera in Polyclinidae

Tabela 10. Chave para gêneros em Polyclinidae.

1. Number of lobes of the oral siphon

2. Margin of pharyngeal transverse vessels papillated: $\mathrm{P}$ - Present (Figure 15g); 0 - Absent

3. Peduncle connecting the abdomen to the post-abdomen: P - Present; 0 - Absent

4. Stomach wall: $A$-Areolate; $P$ - Plicate; $S$-Smooth

\begin{tabular}{ccccc}
\hline $\mathbf{1}$ & $\mathbf{2}$ & $\mathbf{3}$ & $\mathbf{4}$ & Genera \\
\hline 6 & $\mathrm{P}$ & $\mathrm{P}$ & $\mathrm{S}$ & Polyclinum \\
6 & 0 & $\mathrm{P}$ & $\mathrm{S}$ & Aplidiopsis \\
6 & 0 & 0 & $\mathrm{~S}, \mathrm{~A}$ & Synoicum \\
6,8 & 0 & 0 & $\mathrm{P}$ & Aplidium \\
8 & 0 & 0 & $\mathrm{~A}$ & Morchellium \\
\hline
\end{tabular}

(Figure $7 \mathrm{a}$ ) or in a small pouch projecting from the thorax at the anus level.

Polyclinum arenosum (Sluiter, 1898b): South Africa.

Polyclinum aurantium Milne-Edwards 1841: Faroe Islands, Norway, Netherlands, Belgium, Shetland Islands, U.K., Azores, Cape Verde, Senegal, Sierra Leone, Ghana, Brazil (Rio de Janeiro) Polyclinum constellatum Savigny, 1816: Bermuda, U.S. (Florida), Bahamas, Cuba, Jamaica, Puerto Rico, Dominican Republic, St. Martin, Guadeloupe, Barbuda, Mexico, Belize, Panama, Colombia, Aruba, Curaçao, Bonaire, Venezuela, Brazil (Ceará, Espírito Santo to Santa Catarina).

Polyclinum isipingense Sluiter, 1898b: South Africa.

Polyclinum maeandrium Sluiter, 1915: Mauritania.

Polyclinum molle Rocha \& Costa, 2005: Brasil (Rio de Janeiro). Polyclinum neptunium Hartmeyer, 1912: South Africa, Vema Seamount.

Polyclinum reticulatum Sluiter, 1915: Mauritania.

Aplidiopsis Lahille, 1890 (Figure 17a)

Colonies and zooid structure very similar to Polyclinum, the main difference being the lack of papillated transverse vessels in the pharynx and the vertical position of the untwisted abdomen.

Aplidiopsis atlanticus Monniot, 1974: Azores.

Aplidiopsis stellatus Monniot \& Monniot, 1984: Belize, Cuba, Guadeloupe.

\section{Synoicum Phipps, 1774 (Figure 17b)}

Cold water genera with colonies massive or lobed, with or without a peduncle. Zooids elongated. Pharynx with eight or more rows of stigmata. Abdomen not very long; stomach with typhlosole and smooth or areolate wall. Atrial siphons tubular with or without an atrial languet. Longitudinal musculature extends to the post-abdomen.

Synoicum adareanum (Herdman, 1902): South Sandwich

Islands, Antarctic.

Synoicum atlanticum Millar, 1968: Vema Seamount

Synoicum australe Millar, 1962: South Africa, Vema Seamount. Synoicum diaphanum Sluiter, 1927: Cape Verde.

Synoicum georgianum (Sluiter, 1932): Magellan region.

Synoicum pulmonaria (Ellis \& Solander, 1786): Greenland,

Canada, U.S. (Maine), Spitzberg/Svalbard, Bear Island, Iceland,

Norway, Skagerrak Strait, Germany, Netherlands, Belgium, U.K.,

English Channel, Spain, Morocco.

Aplidium Savigny, 1816 (Figure 17c)

Colonies with gelatinous tunic sometimes containing sand, encrusting and thick, or cushion-like, or forming lobes. Zooids 

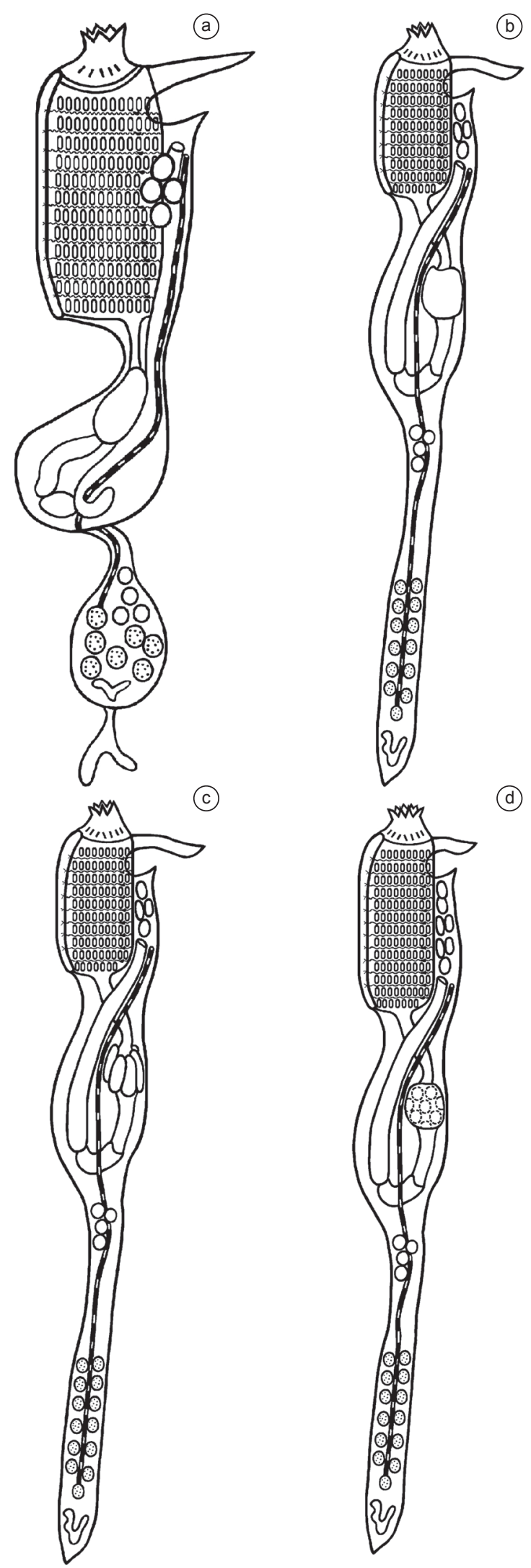

Figure 17. Polyclinidae. a) Polyclinum or Aplidiopsis; b) Synoicum; c) Aplidium; d) Morchellium.

Figura 17. Polyclinidae. a) Polyclinum ou Aplidiopsis; b) Synoicum; c) Aplidium; d) Morchellium. elongated and thin (Figure 5c). An atrial languet is usually visible in relaxed zooids. Thoracic longitudinal musculature extends along the post-abdomen. Pharynx with six or more rows of stigmata; transverse muscle fibers between them. Posterior stomach and rectal valve present in the abdomen. Larval trunk no longer than $1 \mathrm{~mm}$; ectodermic vesicles usually present.

Aplidium accarense (Millar, 1953): Panama, Venezuela, Brazil

(São Paulo, Santa Catarina), Cape Verde, Senegal, Ghana. Aplidium albicans (Milne Edwards, 1841): France, Portugal, Senegal.

Aplidium antillense (Gravier, 1955): Bermuda, U.S. (Georgia),

Belize, Jamaica, Guadeloupe.

Aplidium appendiculatum (Michaelsen, 1923): Azores. Aplidium asperum Drasche, 1883: Spain.

Aplidium bermudae (Van Name, 1902): Bermuda, U.S. (North Carolina to Florida), Mexico, Belize, Jamaica, Guadeloupe, Virgin Islands, Curaçao, Venezuela, Azores.

Aplidium bilinguae Monniot \& Monniot, 1983: South Georgia Islands.

Aplidium circumvolutum (Sluiter, 1900): Falkland Island, South Shetland Islands.

Aplidium cyaneum Monniot \& Monniot, 1983: South Shetland Islands.

Aplidium circulatum (Hartmeyer, 1912): South Africa.

Aplidium colelloides (Herdman, 1886): Namibia, South Africa. Aplidium constellatum (Verrill, 1871): U.S. (New Hampshire

to Florida), Guadeloupe.

Aplidium cunhese Millar, 1967: Tristan da Cunha.

Aplidium dakarensis (Pérès, 1948): Senegal.

Aplidium densum (Giard, 1872): Portugal.

Aplidium elegans (Giard, 1872): English Channel, France,

Spain, Portugal.

Aplidium erythraeum (Michaelsen, 1919): South Africa.

Aplidium exile (Van Name, 1902): Bermuda, U.S. (Florida),

Mexico, Belize, Cuba, West Indies, Guadeloupe.

Aplidium falklandicum Millar, 1960a: South Georgia Islands,

South Sandwich Islands, Elephant Island, South Shetland Islands. Aplidium fuegiense (Cunningham, 1871): Argentina, Strait of

Magellan, Falkland Islands, South Shetland Islands, Namibia.

Aplidium funginum (Sluiter, 1898a): Venezuela.

Aplidium glabrum (Verrill, 1871): Greenland, U.S. (Maine to

Rhode Island), Svalbard, Iceland, Norway, Scotland.

Aplidium globosum Herdman, 1886: Argentina, South

Sandwich Islands.

Aplidium imbutum Monniot \& Monniot, 1983: Elephant Island,

South Shetland Islands.

Aplidium irregulare (Herdman, 1886): Argentina, Falkland

Islands, Strait of the Magellan, Tierra del Fuego.

Aplidium lobatum Savigny, 1816: U.S. (Florida), Jamaica,

Puerto Rico, Guadeloupe, Saint Thomas, Brazil (Alagoas, Bahia). Aplidium loricatum (Harant \& Vernières, 1938): South Shetland

Islands.

Aplidium marchei (Monniot, 1969): Senegal.

Aplidium maroccanum (Sluiter, 1927): Senegal.

Aplidium mauritaniae Sluiter, 1915: Mauritania, Senegal.

Aplidium meridianum (Sluiter, 1906): Argentina, Magellan

Region, South Georgia Islands, South Sandwich Islands, South Shetland Islands.

Aplidium millari Monniot \& Monniot, 1994b: South Georgia Islands.

Aplidium multisulcatum Millar, 1977: Brazil (Maranhão, Rio Grande do Norte). 
Aplidium nordmanni (Milne-Edwards, 1841): Norway, U.K., Spain, Portugal.

Aplidium pallidum (Verrill, 1871): Davis Strait, Canada, U.S. (Maine to Rhode Island), Spitsbergen/Svalbard, Iceland, Faroe Islands, Norway, Orkney Islands, U.K., English Channel, France, Portugal.

Aplidium pantherinum (Sluiter, 1898b): South Africa, Vema Seamount.

Aplidium pellucidum (Drasche, 1883): U.S. (Massachusetts to Florida).

Aplidium pentatrema Monniot, F.: Bermuda, Guadeloupe, Brazil (Paraná).

Aplidium proliferum (Milne-Edwards, 1841): Shetland Islands,

U.K., English Channel, Portugal.

Aplidium punctum (Giard, 1873): U.K., France, Spain, Portugal.

Aplidium quinquesulcatum Millar, 1977: Brazil (Fernando de Noronha, Maranhão to Pernambuco).

Aplidium radiatum (Sluiter, 1906): South Shetland Islands. Aplidium ruzickai Sanamyan \& Gleason 2009: U.S. (Georgia). Aplidium spitzbergense Hartmeyer, 1903: Greenland, Canada,

U.S. (Massachussets), Svalbard, Iceland, Jan Mayen Islandsm, Norway.

Aplidium stellatum (Verrill, 1871): U.S. (Maine to Florida). Aplidium traustedti Millar, 1977: Brazil (Ceará). Aplidium turbinatum (Savigny, 1816): Faroe Islands, Norway, Germany, U.K., English Channel, France, Spain, Mauritania. Aplidium urgorrii Vazquez, 1994: Spain.

Aplidium variabile (Herdman, 1886): Falkland Island, South Georgia Islands.

Aplidium vemense Millar, 1968: Vema Seamount.

\section{Morchellium Giard, 1872 (Figure 17d)}

Colonies claviform, the base or peduncle with the posterior part of the zooids, the head with the thoraxes. Zooids very similar to Synoicum in structure, the main difference is the number of lobes of the oral siphon. Oral siphons with four red spots around the base. Atrial languet small with a tapering end. Pharynx with $12-20$ rows of stigmata. Larvae with ectodermic vesicles in the anterior and ventral regions, but without ampullae. Thorax and abdomen absorbed during winter months.

Morchellium argus (Milne-Edwards, 1841): U.K., France, Spain, Portugal.

\section{Euherdmaniidae Ritter, 1904}

Colonial species with zooids either completely embedded in a common tunic or united by a stolon. No cloacal systems; both siphons opening at the surface of the colony. Longitudinal musculature extends to the post-abdomen; transverse musculature present on the thorax. Pharynx with $12-20$ rows of stigmata. Stomach wall plicated. Post-abdomen usually short (same length or smaller than the abdomen). Larvae usually longer than $0.8 \mathrm{~mm}$ with two tubular eversible adhesive papillae (although the larvae from $E$. areolata, E. rodei and E. solida are unknown).

Euherdmania (Ritter, 1904) (Figure 18a)

Only genus in the family, with same description.

Euherdmania areolata Millar, 1978: Guyana, Suriname.

Euherdmania claviformis (Ritter, 1903): Senegal.

Euherdmania fasciculata Monniot, 1983b: Belize, Guadeloupe.

Euherdmania morgani Millar \& Goodbody, 1974: Jamaica.

Euherdmania rodei Pérès, 1949: Senegal.

Euherdmania solida Millar, 1953: Senegal, Ghana.

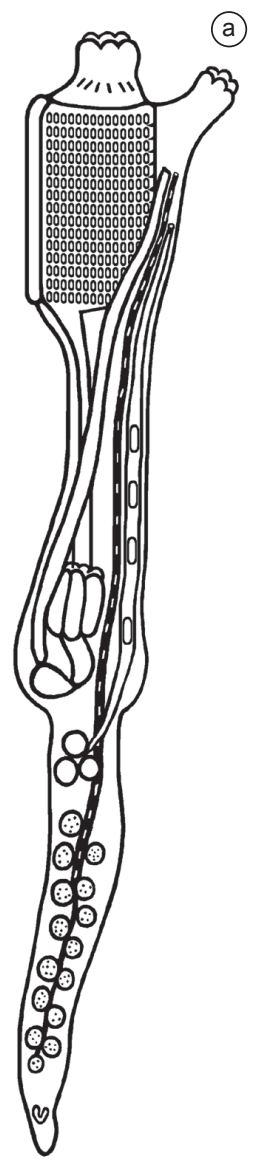

(b)

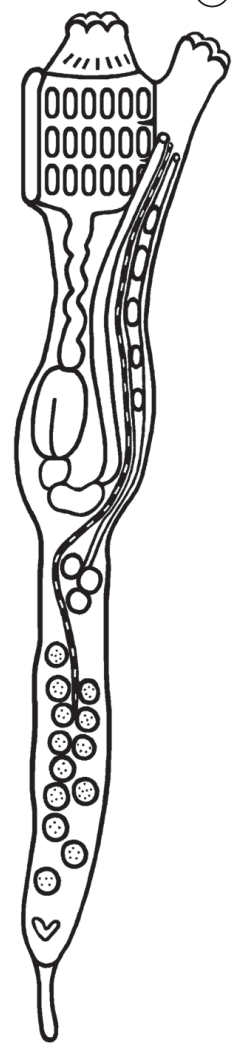

Figure 18. Euherdmaniidae \& Pseudodistomidae. a) Euherdmania; b) Pseudodistoma.

Figura 18. Euherdmaniidae \& Pseudodistomidae. a) Euherdmania; b) Pseudodistoma.

Euherdmania vitrea Millar, 1961: Brazil (São Paulo, Santa Catarina).

\section{Pseudodistomidae Kott, 1992}

Colonies usually stalked with zooids completely embedded in the common tunic with both siphons opening at the surface of the colony. Siphons with six lobes. Thorax very similar to Eudistoma with three rows of stigmata. Thoracic longitudinal musculature extending along the post-abdomen. Stomach divided into four chambers. Gonads arranged linearly or in a cluster inside the post-abdomen. Larval trunk longer than $1 \mathrm{~mm}$, with three adhesive papillae linearly arranged. Stolonic vessel usually longer than in Polycitoridae.

Pseudodistoma Michaelsen, 1924 (Figure 18b)

Only genus in the family, with same description.

Pseudodistoma africanum Millar, 1954a: South Africa.

Pseudodistoma brieni Pérès, 1949: Senegal.

Pseudodistoma cereum Michaelsen, 1924: Senegal.

Pseudodistoma michaelseni Millar, 1968: Africa.

Pseudodistoma saxicavum Gaill, 1972: Bermuda.

Styelidae Sluiter, 1895 (Table 11)

Large family with species either colonial or solitary, with variable sizes. Solitary forms with a thin leathery tunic and body as a sac with the alimentary canal on the left side of the pharynx. Some colonial forms with a more delicate tunic, others with a tough leathery tunic. 
Rocha, R.M. et al.

Table 11. Key for genera in Styelidae.

Tabela 11. Chave para gêneros em Styelidae.

1. Mode of life: $\mathrm{S}$ - Solitary; $\mathrm{C}$ - Colonial

2. If colonial: $\mathrm{C}$ - Atrial siphons opening into cloacal systems; $\mathrm{S}$ - Atrial siphons opening on the surface of the colony

3. Pharynx wall: F - With folds; V - Without folds, with longitudinal vessels

4. Pharyngeal stigmata: $\mathrm{L}$ - Straight and longitudinal (parallel to the endostyle); $\mathrm{T}$ - Straight and transverse (perpendicular to the endostyle)

5. Parastigmatic vessels: $P$ - Present (Figure 15d); 0 - Absent

6. Gonads: H - Hermaphrodite (Figure 23); S - Male and female gonads separate (Figure 21)

7. Hermaphrodite gonads: $\mathrm{E}$ - enclosed in a common membrane or capsule (Figure 23c, d), N - non encapsulated (testes attached to ovary by sperm ducts) (Figure 23e, f)

8. Shape of the gonad: $\mathrm{E}$ - elongate; $\mathrm{G}$ - globular; $\mathrm{O}$ - oval or eliptical; $\mathrm{R}$ - elongate and ramified

9. Number of male follicles in each gonad

10. Gonad location: B - Both sides; $\mathrm{R}$ - Right side

11. Number of gonads in each side of the body

\begin{tabular}{|c|c|c|c|c|c|c|c|c|c|c|c|}
\hline 1 & 2 & 3 & 4 & 5 & 6 & 7 & 8 & 9 & 10 & 11 & Genera \\
\hline $\mathrm{S}$ & - & $\mathrm{F}$ & $\mathrm{L}$ & $\mathrm{P}$ & $\mathrm{H}$ & $\mathrm{N}$ & $\mathrm{E}$ & $>20$ & B & $2-8$ & Styela \\
\hline $\mathrm{S}$ & - & $\mathrm{F}$ & $\mathrm{L}$ & 0 & $\mathrm{H}$ & $\mathrm{E}$ & $\mathrm{R}$ & $>20$ & B & $1-12$ & Cnemidocarpa \\
\hline $\mathrm{S}$ & - & $\mathrm{F}$ & $\mathrm{L}$ & $0, \mathrm{P}$ & $\mathrm{H}$ & $\mathrm{E}$ & $\mathrm{O}$ & $>8$ & B & $>10$ & Polycarpa \\
\hline $\mathrm{S}$ & - & $\mathrm{F}^{1}$ & $\mathrm{~L}$ & 0 & $\mathrm{H}$ & $\mathrm{E}$ & $\mathrm{E}$ & $>8$ & $\mathrm{R}$ & 1 & Dendrodoa \\
\hline $\mathrm{S}$ & - & $\mathrm{V}$ & $\mathrm{L}$ & 0 & $\mathrm{H}$ & $\mathrm{N}$ & $\mathrm{E}$ & $>20$ & B & 1 & Pelonaia \\
\hline $\mathrm{C}$ & $\mathrm{C}$ & $\mathrm{V}$ & $\mathrm{L}$ & 0 & $\mathrm{~S}$ & $\mathrm{~N}$ & G & $5-20$ & B & 1 & Botryllus or Botrylloides \\
\hline $\mathrm{C}$ & $\mathrm{S}$ & $\mathrm{V}$ & $\mathrm{L}$ & 0 & $\mathrm{H}$ & $\mathrm{N}$ & G & 2 & $\mathrm{~B}$ & 1 & Symplegma \\
\hline $\mathrm{C}$ & $\mathrm{S}$ & $\mathrm{V}$ & $\mathrm{L}$ & 0 & $\mathrm{H}$ & $?$ & G & 1 & $\mathrm{~B}$ & $>1$ & Polyzoa \\
\hline $\mathrm{C}$ & $\mathrm{S}$ & $\mathrm{V}$ & $\mathrm{L}^{2}$ & $\mathrm{P}$ & $S^{3}$ & $\mathrm{~N}$ & G & 1 & B & $>1$ & Metandrocarpa \\
\hline $\mathrm{C}$ & $\mathrm{S}$ & $\mathrm{V}$ & $\mathrm{L}$ & 0 & $\mathrm{~S}$ & $\mathrm{~N}$ & G & 1 & B & $>1$ & Alloeocarpa \\
\hline $\mathrm{C}^{4}$ & $\mathrm{~S}$ & $\mathrm{~F}^{5}$ & $\mathrm{~L}$ & 0 & $\mathrm{H}$ & $\mathrm{N}$ & G & $?$ & $\mathrm{R}$ & $>1$ & Dextrocarpa \\
\hline $\mathrm{C}$ & $\mathrm{S}$ & $\mathrm{F}$ & $\mathrm{L}$ & $0, \mathrm{P}$ & $\mathrm{H}$ & $\mathrm{E}$ & $\mathrm{O}$ & $>8$ & $\mathrm{~B}$ & $>5$ & Polyandrocarpa \\
\hline $\mathrm{C}$ & $\mathrm{S}$ & $\mathrm{F}^{5}$ & $\mathrm{~L}$ & $0, \mathrm{P}$ & $\mathrm{H}$ & $\mathrm{E}$ & $\mathrm{O}$ & 2 & $\mathrm{~B}$ & $>5$ & Eusyntyela \\
\hline $\mathrm{C}$ & $\mathrm{S}$ & $\mathrm{F}$ & $\mathrm{L}$ & $0, \mathrm{P}$ & $\mathrm{S}$ & $\mathrm{N}$ & G & $>1$ & B & $>1$ & Stolonica $^{6}$ \\
\hline $\mathrm{C}$ & $\mathrm{S}$ & $\mathrm{F}$ & $\mathrm{L}$ & $0, \mathrm{P}$ & S & $\mathrm{N}$ & G & 1 & B & $>1$ & Distomus $^{6}$ \\
\hline $\mathrm{C}$ & $\mathrm{S}$ & $\mathrm{F}$ & $\mathrm{L}$ & 0 & $\mathrm{H}, \mathrm{S}$ & $\mathrm{N}$ & G & 1 & B & $>1$ & Amphicarpa $^{6}$ \\
\hline $\mathrm{C}$ & $\mathrm{S}$ & $\mathrm{F}$ & $\mathrm{L}$ & $\mathrm{P}$ & $\mathrm{H}$ & $\mathrm{E}$ & G & 1 & B & $>5$ & Monandrocarpa \\
\hline $\mathrm{C}$ & $\mathrm{S}$ & $\mathrm{V}$ & $\mathrm{T}$ & 0 & $\mathrm{H}, \mathrm{S}$ & $\mathrm{E}$ & G & 1 & $\mathrm{~B}$ & $3(\mathrm{D}) ; 1(\mathrm{E})$ & Protostyela \\
\hline $\mathrm{C}$ & $\mathrm{S}$ & $\mathrm{F}$ & $\mathrm{T}$ & 0 & $\mathrm{H}$ & $\mathrm{E}$ & G & 2 & B & 1 & Tibitin \\
\hline
\end{tabular}

${ }^{1}$ Might be absent in juveniles and in non-Atlantic species. ${ }^{2}$ Protostigmas in the posterior region. ${ }^{3}$ Sequencial hermaphroditism. ${ }^{4}$ Individuals might separate after budding. ${ }^{5}$ Might be rudimentary. ${ }^{6}$ Amphicarpa and Distomus have male gonads only on the left side; Stolonica has male gonads on both sides. Amphicarpa and Stolonica have female gonads in both sides; Distomus has female gonad only on the right side.

Zooids united by a stolon or embedded in a common tunic, body in only one part in both solitary and colonial forms, although botryllids have the stomach posterior to the pharynx (Figure 5a). The family is well characterized by the simultaneous presence of simple tentacles, continuous dorsal lamina, folded stomach and four pharyngeal folds on each side (this last character exclusive to solitary forms). Frequent presence of endocarps attached to the body wall and/or to the intestine (Figure 19e).

\section{Styela Fleming, 1822 (Figure 20a)}

Solitary ascidians sometimes with a small peduncle. Tunic thin but leathery and opaque. Body wall with thin muscle fibers both longitudinal and transverse. Endocarps in some species, on the body wall and intestine. Stomach usually elongated and folded; without caecum. More than one gonad in each side: ovary elongated, rarely ramified, completely attached to the body wall; male follicles elongate and ramified, surrounding the ovary but not in close contact (Figure 23e). One sperm duct per gonad along the atrial wall of the ovary.
Styela aequatorialis Michaelsen, 1915: Guinea, South Africa. Styela angularis (Stimpson, 1855): South Africa.

Styela canopus (Savigny, 1816): Canada, U.S. (Maine to South Carolina), Bermuda, Cuba, Jamaica, Puerto Rico, Grenada, Guadeloupe, Martinique, Belize, Panama, Aruba, Curaçao, Bonaire, Venezuela, Brazil (Ceará to Santa Catarina), U.K., France, Mauritania, Cape Verde, Senegal, Sierra Leone, Ghana, South Africa.

Styela clava Herdman, 1881: Canada, U.S. (Maine to Massachusetts), U.K., France, Spain.

Styela coriacea (Alder \& Hancock, 1848): Greenland, Davis Strait, Canada, U.S. (Maine, Massachusetts), Spitsbergen/ Svalbard, Iceland, Norway, Denmark, Germany, U.K., English Channel.

Styela eurygaster Millar, 1977: Brazil (Amapá, Rio Grande do Norte).

Styela gelatinosa (Traustedt, 1886): Greenland, Davis Strait, Iceland, Faroe Islands, Norway, Skagerrak Strait.

Styela glans Herdman, 1881: Brazil (São Paulo), Argentina. 

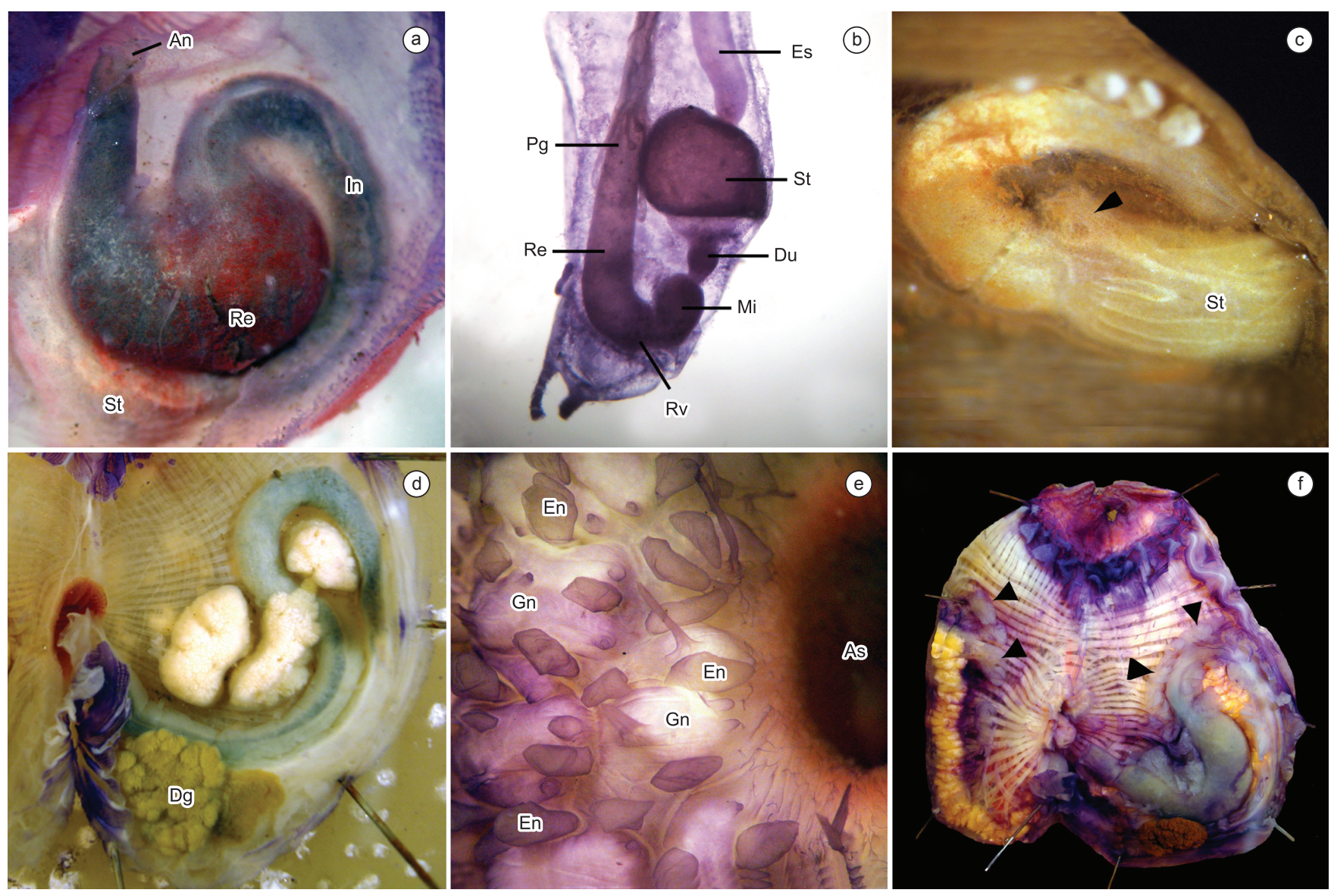

Figure 19. a) Ascidia sydneiensis - dilated rectum $(\mathrm{An}=$ anus, $\mathrm{In}=$ intestine, $\mathrm{Re}=$ rectum, $\mathrm{St}=\mathrm{stomach})$; $\mathrm{b})$ Eudistoma clarum - abdomen $(\mathrm{Du}=\mathrm{duodenum}$, Es = esophagus; $\mathrm{Mi}=$ medium intestine; $\mathrm{Pg}=$ pyloric gland; $\mathrm{Re}=$ rectum, $\mathrm{Rv}=$ rectal valve, $\mathrm{St}=$ stomach); $)$ Eusynstyela sp. - stomach with plicate wall and pyloric caecum (arrowhead); d) Microcosmus exasperatus - digestive gland (Dg) covering the stomach; e) Polycarpa insulsa - right side showing endocarps on the body wall (En), embedded gonads (Gn) and the atrial siphon aperture (As); f) Pyura vannamei - endocarps on body wall and on intestine.

Figura 19. a) Ascidia sydneiensis - reto dilatado (An = ânus, $\mathrm{In}=$ intestino, $\mathrm{Re}=$ reto, $\mathrm{St}=$ estômago); b) Eudistoma clarum - abdome $($ Du $=$ duodeno, Es = esôfago; $\mathrm{Mi}$ = intestino médio; $\mathrm{Pg}=$ glândula pilórica; $\mathrm{Re}=$ reto, $\mathrm{Rv}=$ válvula retal, $\mathrm{St}=$ estômago); c) Eusynstyela sp. - Estômago com parede plicada e ceco pilórico (seta); d) Microcosmus exasperatus - glândula digestiva (Dg) cobrindo o estômago; e) Polycarpa insulsa - lado direito mostrando endocarpos sobre a parede do corpo (En), gônadas embebidas na parede (Gn) e a abertura do sifão atrial (As); f) Pyura vannamei - endocarpos na parede do corpo e no intestino.

Styela magalhaensis Michaelsen, 1898: Strait of Magellan. Styela paessleri (Michaelsen, 1898): Strait of Magellan, Tierra del Fuego, Falkland Islands, South Georgia Islands.

Styela plicata (Lesueur, 1823): Bermuda, U.S. (North Carolina, Florida), Cuba, Jamaica, Guadeloupe, Brazil (Bahia, Rio de Janeiro to Santa Catarina), Argentina (Mar del Plata), Mauritania, Senegal, South Africa .

Styela rustica (Linnaeus, 1767): Greenland, Davis Strait, Canada, U.S. (Maine to Connecticut), Spitsbergen/Svalbard, Iceland, Faroe Islands, Norway, Skagerrak Strait, Denmark, Germany.

Styela schmitti Van Name, 1945: Uruguay.

Styela sigma (Van Name, 1912): U.S., Norway, Skagerrak Strait, Azores.

Styela theeli Arnback, 1922: Skagerrak Strait.

Cnemidocarpa Huntsman, 1912 (Figure 20b)

Solitary ascidians with thin but leathery tunic, similar to Styela. Endocarps might be present. Gonads elongate, tubular and occasionally ramified as a compact mass contained in a membrane; well attached to the body wall. Male follicles surrounding the ovary or between the ovary and the body wall; one sperm duct per gonad. Many species lack the larval ocellus. No brooding.

Cnemidocarpa calypso Monniot, 1970: Argentina.

Cnemidocarpa finmarkiensis (Kiaer, 1893): Greenland, Canada, Norway.

Cnemidocarpa irene (Hartmeyer, 1906): Guadeloupe, Morocco, Cape Verde, Brazil (Ceará, Bahia, São Paulo)

Cnemidocarpa mollis (Stimpson, 1852): U.S. (Maine to

Connecticut), Shetland Islands, Orkney Islands, U.K.

Cnemidocarpa mortenseni (Hartmeyer, 1912): Davis Strait,

Canada, U.S. (Massachusetts), Iceland, Norway, Skagerrak Strait. Cnemidocarpa nordenskjoldi (Cunningham, 1871): Argentina, Strait of Magellan, Antarctic.

Cnemidocarpa ohlini (Michaelsen, 1898): Strait of Magellan. Cnemidocarpa rhizopus (Redikorzev, 1907): Greenland,

Canada, Spitsbergen/Svalbard, Iceland, Norway.

Cnemidocarpa verrucosa (Lesson, 1830): Argentina, Falkland Islands, South Georgia Islands.

Polycarpa Heller, 1877 (Figure 20c)

Solitary ascidians of various sizes and sometimes aggregated in large numbers. Endocarps on the body wall and inside the intestinal 

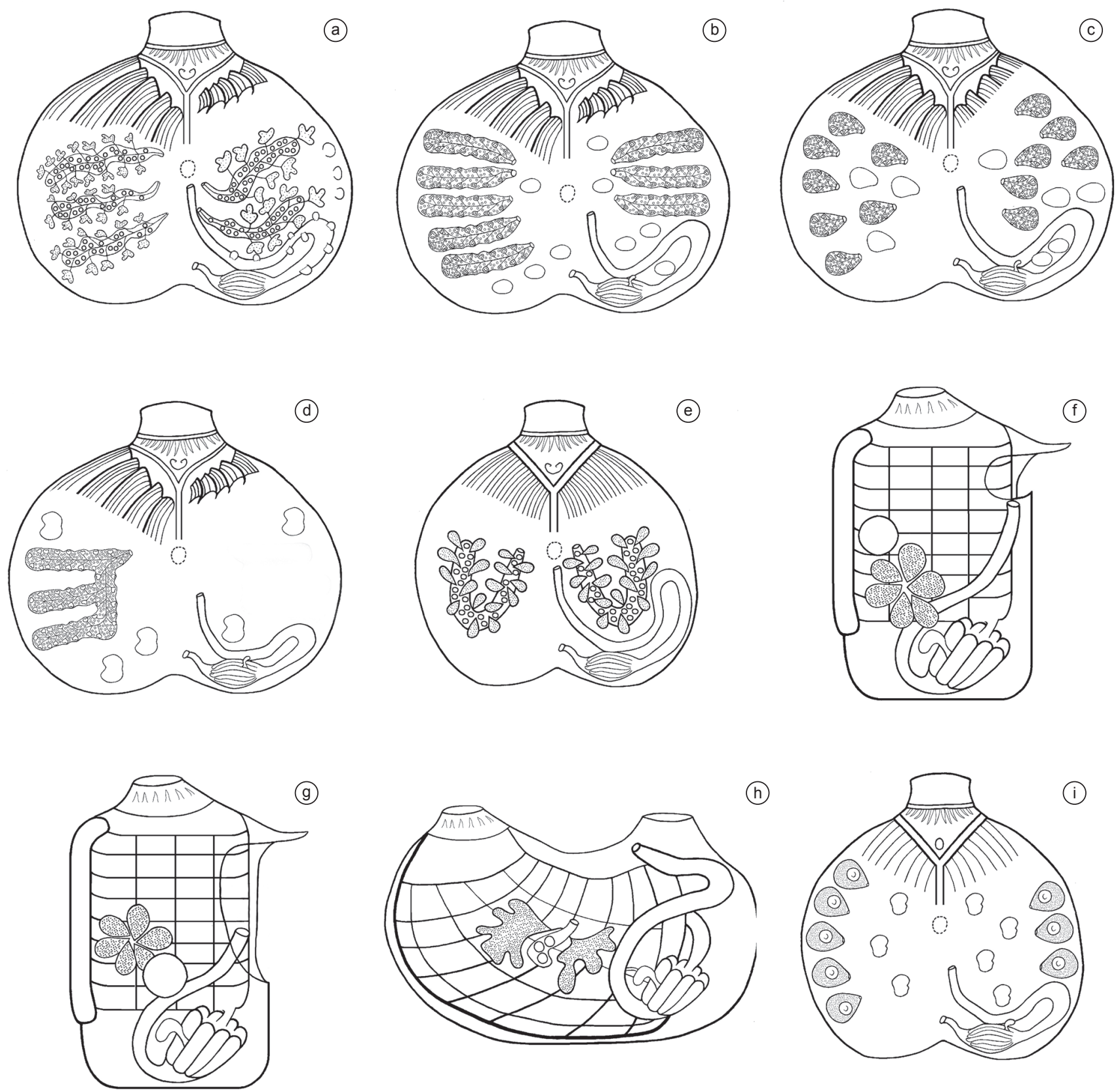

Figure 20. Styelidae. a) Styela; b) Cnemidocarpa; c) Polycarpa or Polyandrocarpa; d) Dendrodoa; e) Pelonaia; f) Botryllus; g) Botrylloides; h) Symplegma; i) Polyzoa.

Figura 20. Styelidae. a) Styela; b) Cnemidocarpa; c) Polycarpa ou Polyandrocarpa; d) Dendrodoa; e) Pelonaia; f) Botryllus; g) Botrylloides; h) Symplegma; i) Polyzoa.

loop (Figure 19e). Gastric caecum might be present at the pyloric region of the stomach. Gonads small and numerous, oval or round, with one sperm duct per gonad (Figure 23c). Gonads are sometimes embedded in the body wall and other times, very loosely attached.

Polycarpa ärnbäckae Monniot, 1964: Sweden.

Polycarpa appropinquata (Sluiter, 1898a): Venezuela, Suriname, Guyana.

Polycarpa arnoldi (Michaelsen, 1914): U.S. (Florida), Cuba, Guadeloupe, Martinique, St. Martin, Panama, Colombia, Curaçao, Bonaire, Brazil (Bahia), Cape Verde, Guinea.
Polycarpa aspera (Herdman, 1886): Argentina, South Georgia Islands.

Polycarpa aurita (Sluiter, 1890): Belize.

Polycarpa cartilaginea (Sluiter, 1898a): Cuba, Guadeloupe, Belize, Panama, Colombia, Curaçao.

Polycarpa comata (Alder, 1863): Portugal, Gibraltar Strait.

Polycarpa distomaphila Millar, 1953: Ghana.

Polycarpa fibrosa (Stimpson, 1852): Greenland, Canada (Prince Edward Island), U.S. (Maine to Massachusetts), Spitsbergen/Svalbard, Iceland, Faroe Islands, Norway, Skagerrak 
Strait, Sweden, Belgium, Netherlands, U.K., English Channel, Portugal, Strait of Gibraltar.

Polycarpa foresti Monniot, 1970: Brazil (Bahia).

Polycarpa goreensis (Michaelsen, 1914): Morocco, Senegal.

Polycarpa gracilis Heller, 1877: English Channel, Scotland, Spain, Portugal, Strait of Gibraltar.

Polycarpa insulsa (Sluiter, 1898a): Mexico, Cuba, Panama, Colombia, Venezuela, Guyana, Suriname.

Polycarpa itapoa Rocha \& Moreno, 2000: Brazil (Santa Catarina).

Polycarpa kornogi Glemarec \& Monniot, 1966: U.K.

Polycarpa longitubis Monniot, Monniot \& Leung Tack, 1987:

Senegal.

Polycarpa mamillaris (Gaertner, 1774): Spain, Portugal, Strait of Gibraltar.

Polycarpa multiplicata Monniot, 1983b: Guadeloupe.

Polycarpa nivosa (Sluiter, 1898b): Cuba, Colombia, Venezuela, Brazil (Ceará, Pernambuco).

Polycarpa pomaria (Savigny, 1816): Iceland, Faroe Islands, Norway, North Sea, Sweden, Denmark, U.K., France, Spain, Portugal, Azores, Strait of Gibraltar.

Polycarpa pulvinum Monniot, 1969: Mauritania, Senegal.

Polycarpa pusilla (Herdman, 1884): Portugal, Azores, Strait of Gibraltar.

Polycarpa quadricarpa Millar, 1953: Ghana.

Polycarpa scuba Monniot, 1971: U.K., English Channel, Spain,

Portugal, Strait of Gibraltar, Azores.

Polycarpa sourieri Pérès, 1949: Senegal.

Polycarpa spongiabilis (Traustedt, 1883): Bermuda, U.S. (Florida), Bahamas, Cuba, Dominican Republic, Jamaica, Puerto Rico, Guadeloupe, Martinique, Antigua \& Barbuda, Mexico, Belize, Panama, Curaçao, Venezuela, Guyana, Suriname, Brazil (Ceará to Bahia, Rio de Janeiro to Santa Catarina).

Polycarpa tenera Lacaze-Duthiers \& Delage, 1892: Spain, Azores.

Polycarpa translucida (Pérès, 1951): Senegal, Sierra Leone.

Polycarpa tumida Heller, 1878: Bermuda, U.S. (Florida),

Jamaica, Guadeloupe, Belize, Panama, Colombia, Curaçao, Venezuela, Brazil (Ceará, Bahia).

Polycarpa violacea (Alder, 1863): Spain, Portugal.

Dendrodoa MacLeay, 1825 (Figure 20d)

Small solitary ascidians with a thin leathery tunic, inhabiting cold water. The pharyngeal folds can be reduced. Stomach usually with a small caecum. The only gonad on the right side of the body, usually ramified with more than one sperm duct per gonad. Without endocarps.

Dendrodoa aggregata (Rathke, 1806): Greenland, Canada, U.S.

(Maine), Spitsbergen/Svalbard, Iceland, Faroe Islands, Norway.

Dendrodoa pulchella (Verrill, 1871): Greenland, Canada, U.S.

(Maine), Spitsbergen/Svalbard.

Dendrodoa carnea (Agassiz, 1850): Canada, U.S. (Maine to North Carolina).

Dendrodoa grossularia (Van Beneden, 1846): Greenland, Davis Strait, Canada, Spitsbergen/Svalbard, Iceland, Faroe Islands, Norway, North Sea, Sweden, Denmark, U.K., English Channel.

\section{Pelonaia Forbes \& Goodsir, 1841 (Figure 20e)}

Solitary ascidian with a long cylindrical body. The alimentary canal is posterior to the pharynx. Sixteen to 20 longitudinal vessels on each side of the pharynx, no folds. Body wall without endocarps. One gonad in each side of the body; ovary in the secondary intestinal loop, as a long tube forming a posterior loop with the two halves almost parallel. One sperm duct per gonad, running along the ovary. Pelonaia corrugata Forbes \& Goodsir, 1841: Greenland, Canada, U.S. (Massachusetts), Spitsbergen/Svalbard, Faroe Islands, Norway, Skagerrak Strait, North Sea,U.K.

\section{Botryllus Gaertner, 1774 (Figure 20f)}

Colonial ascidian with zooids completely embedded in the tunic, organized in circular or elliptical systems around the common cloaca. According to Brunetti (2009) the structure of the cloaca is the best way to differentiate this genus from Botrylloides: "The cloaca is a small well, the wall of which is formed by the lateral fusion of the dorsal languets of the atrial openings. The atrial openings are located at the distal end of a conical siphon. All the zooids of a system are involved in the construction of the cloaca. This means that only a limited number of zooids can be arranged in a system. Systems with up to eight zooids are usually typically star-shaped; when a greater number of zooids have to be arranged, the system become elliptical, and the same happens to the shape of the cloacal opening. Of course, ovoidation of the system involves lengthening of the atrial siphons of the zooids arranged at the two poles of the ellipse". The stomach is posterior to the pharynx with a gastric caecum, while most of the intestine lies beside it. Three longitudinal vessels on each side of the pharynx. Ovary with one to three oocytes in each side, anterior or dorsal to the testis, which is round with numerous follicles. According to Okuyama \& Saito (2001): all species are ovoviviparous, some without a brooding organ (incubation inside the atrial cavity), some forming brooding organs with different structures from each other. Body wall without endocarps.

Botryllus planus (Van Name, 1902): U.S. (Florida), Bermudas, Belize, Guadeloupe, Panama, Curaçao, Brazil (Ceará, Bahia, São Paulo, Paraná).

Botryllus schlosseri (Pallas, 1766): Canada, U.S. (Maine to Florida), Bermuda, Cuba, Argentina (Mar del Plata), Faroe Islands, Norway, Skagerrak Strait, North Sea, U.K., English Channel, France, Spain, Cape Verde, Senegal, South Africa.

Botryllus tabori Rodrigues, 1962: Brazil (Ceará, Alagoas, Bahia to São Paulo).

Botryllus tuberatus Ritter \& Forsyth, 1917: U.S. (Florida), Guadeloupe, Belize, Panama, Brazil (Rio Grande do Norte to Alagoas, São Paulo to Santa Catarina).

\section{Botrylloides Milne-Edwards, 1841 (Figure 20g)}

Very similar to Botryllus. Zooids completely embedded in the tunic, organized in long meandering systems around the common cloaca. According to Brunetti (2009): "there are no atrial siphons and the atrial opening is wide, usually with a broad dorsal lip extending from its anterior rim. The zooids approach each other side by side, usually in an almost vertical position, defining a wide cloacal canal in which the branchial sacs of the zooids face each other. The roof of the canal is formed of the dorsal lips fused together. From time to time, there are cloacal openings along the roof of the canal, with edges formed by the unjoined dorsal lips of a few zooids; not all zooids of a system are involved in the construction of the cloaca. Such a structure permits the formation of meandering systems of an unlimited number of zooids. Circular or oval systems are also possible and the only ones present in young colonies." The stomach is posterior to the pharynx with a gastric caecum, while most of the intestine lies beside it. Three longitudinal vessels on each side of the pharynx. Ovary with one oocyte in each side, posterior to the testis, which is round with numerous follicles. According to Okuyama \& Saito (2001): although there are ovoviviparous and viviparous species in this genus, their brood pouches have the 
same origin and structure. All species make the brood pouches by invagination of peribranchial epithelium near the ovary. Body wall without endocarps.

Botrylloides anceps (Herdman, 1891): Brazil (São Paulo)

Botrylloides aureum (Sars, 1851): Greenland, Davis Strait,

Canada, U.S. (Maine), Spitsbergen/Svalbard, Iceland e Norway.

Botrylloides giganteum (Pérès, 1949): Brazil (Espírito Santo

to São Paulo, Santa Catarina), Senegal.

Botrylloides leachii (Savigny, 1816): Norway, U.K., Scotland, Spain, Senegal.

Botrylloides nigrum Herdman, 1886: U.S. (Florida, Texas), Bahamas, Grand Cayman, Cuba, Haiti, Jamaica, Puerto Rico, Guadeloupe, St. Martin, Martinique, Mexico, Belize, Colombia, Aruba, Curaçao, Bonaire, Venezuela, Brazil (Ceará, Paraíba to Santa Catarina), Morocco, Cape Verde, Senegal, Sierra Leone. Botrylloides perspicuum Herdman, 1886: Bermuda, Belize.

Botrylloides violaceus Oka, 1927: Canada (Newfoundland,

Prince Edward Island), U.S. (Maine to Massachusetts).

\section{Symplegma Herdman, 1886 (Figure 20h)}

Colonial ascidian with zooids embedded in a common, thin, transparent tunic. Zooids ovate with both siphons opening on the surface of the colony. Four longitudinal vessels on each side of the pharynx. Gastric caecum present. One globular ovary in each side of the body with the male follicles anterior and posterior (Figure 23f), one sperm duct per gonad. Body wall without endocarps. Brooding in the atrial cavity.

Symplegma brakenhielmi (Michaelsen, 1904): Bermuda, U.S. (North Carolina to Florida), Jamaica, Puerto Rico, Guadeloupe, Mexico, Belize, Panama, Venezuela, Brazil (Pará to Santa Catarina), Senegal, Ghana.

Symplegma rubra Monniot, 1972: Bermuda,U.S. (Florida, Gulf of Mexico), Jamaica, Guadeloupe, Belize, Panama, Venezuela, Brazil (Ceará, Espírito Santo to Santa Catarina).

Symplegma viride Herdman, 1886: Bermuda, U.S. (Florida), Grand Cayman, Cuba, Jamaica, Grenada, Guadeloupe, Curaçao, Bonaire, Senegal.

\section{Polyzoa Lesson, 1830 (Figure 20i)}

Colonial ascidian with zooids united by a thin layer of tunic. Both siphons opening on the surface of the colony. Pharynx with no folds but with eight longitudinal vessels on each side. Endocarps might occur on the body wall. Gonads in a line at each side of the endostyle, formed by the ovary and a single testis follicle. Only male gonads in the beginning of the breeding period, or only male follicles in the most anterior gonads. Few oocytes, maturing one at a time per gonad.

Polyzoa atlantica Sanamyan, Gleason \& Sanamyan 2009:

U.S. (Georgia).

Polyzoa insularis Millar, 1967: Tristan da Cunha.

Polyzoa opuntia Lesson, 1830: Argentina, Strait of Magellan, Falkland Islands, South Georgia Island.

Polyzoa reticulata (Herdman, 1886): Argentina, Falkland Islands, South Georgia Island.

\section{Metandrocarpa Michaelsen, 1904 (Figure 21a)}

Colonial ascidian with separated zooids covered by a thin tunic. Zooids 2-3 mm long, with both siphons opening on the surface of the colony. Protostigmas present in the posterior region of the pharynx; seven to 10 longitudinal vessels in each side. Numerous endocarps on the body wall. Gastric caecum present. Colonies either male or female at a time; male gonads distant from the endostyle, while female gonads closer to it; testis with one follicle, lobed or not, one ventral sperm duct per gonad, while the oviduct is dorsal. Brooding inside the atrial cavity.
Metandrocarpa sterreri Monniot, 1972: Bermuda, Guadeloupe.

\section{Alloeocarpa Michaelsen, 1900 (Figure 21b)}

Colonial ascidian with zooids united by a tough and leathery tunic or by stolons. Usually reddish in color. Both siphons opening on the surface of the colony. Five to 16 longitudinal vessels on each side of the pharynx. Endocarps present on both sides of the body wall. A gastric caecum might be present. Male and female gonads separate, sometimes in opposite sides of the body. Ovary globular; male follicles lobed or not. Brooding inside the atrial cavity.

Alloeocarpa aequatorialis Millar, 1953: Ghana

Alloeocarpa bridgesi Michaelsen, 1900: Strait of Magellan,

Tierra del Fuego.

Alloeocarpa incrustans (Herdman, 1886): Argentina, Antarctic. Alloeocarpa loculosa Monniot, 1974: Azores.

\section{Dextrocarpa Millar, 1955 (Figure 21c)}

Colonial ascidian with zooids united by a slender stolon or separated. Both siphons opening on the surface of the colony. Pharynx with three folds, the ventral rudimentary. Endocarps absent. Gastric caecum present. Gonads only on the right side of the body. Brooding of larvae inside a pouch formed by the enlargement of the oviduct; no permanent connection between this pouch and the atrial cavity.

Dextrocarpa solitaris Millar, 1955: South Africa.

\section{Polyandrocarpa Michaelsen, 1904 (Figure 20c)}

Colonial ascidians with zooids embedded in a common leathery tunic or united by stolons. Zooids usually in a vertical position, with both siphons opening on the surface of the colony. Pharynx with four folds per side. Numerous gonads in each side of the body, with the same structure as in Polycarpa: ovary with many oocytes and two lines of male follicles underneath the ovary (Figure 23c). Zooids very similar to Polycarpa, the main difference is the formation of colonies by asexual reproduction and usual absence of endocarps (but $P$. zorritensis has one inside the intestinal loop).

Polyandrocarpa anguinea (Sluiter, 1898b): U.S. (Florida), Martinique, Panama, Brazil (Ceará, Espírito Santo to Santa Catarina), Sierra Leone, South Africa.

Polyandrocarpa pilella (Herdman, 1881): Brazil (Bahia).

Polyandrocarpa placenta (Herdman, 1886): South Africa.

Polyandrocarpa zorritensis (Van Name, 1931): U.S. (Gulf of Mexico, Florida), Brazil (Bahia to Santa Catarina).

\section{Eusynstyela Michaelsen, 1904 (Figure 21d)}

Colonial ascidians with zooids embedded in a common tough, opaque tunic. Zooids usually horizontal, attached to the substrate by the ventral region, with both siphons opening on the surface of the colony. Gonads on both sides, usually arranged along the ventral region: ovary with many oocytes, two male follicles only (Figure 23d); they might project inside the tunic in some species within body wall evaginations (eg. E. tincta). Gastric caecum present (Figure 19c). Body wall with endocarps.

Eusynstyela floridana (Van Name, 1921): U.S. (North Carolina, Florida), Guadeloupe.

Eusynstyela gravei (Van Name, 1931): U.S. (Florida).

Eusynstyela ordinata (Monniot, 1983b): Guadeloupe.

Eusynstyela tincta (Van Name, 1902): Bermuda, U.S. (Florida), Cuba, Jamaica, Guadeloupe, Belize, Panama, Curaçao, Brazil (Ceará to Santa Catarina), Senegal.

Stolonica Lacaze-Duthiers \& Délage, 1892 (Figure 21e)

Colonial with zooids united by stolons. Zooids usually in a vertical position, with both siphons opening on the surface of the 

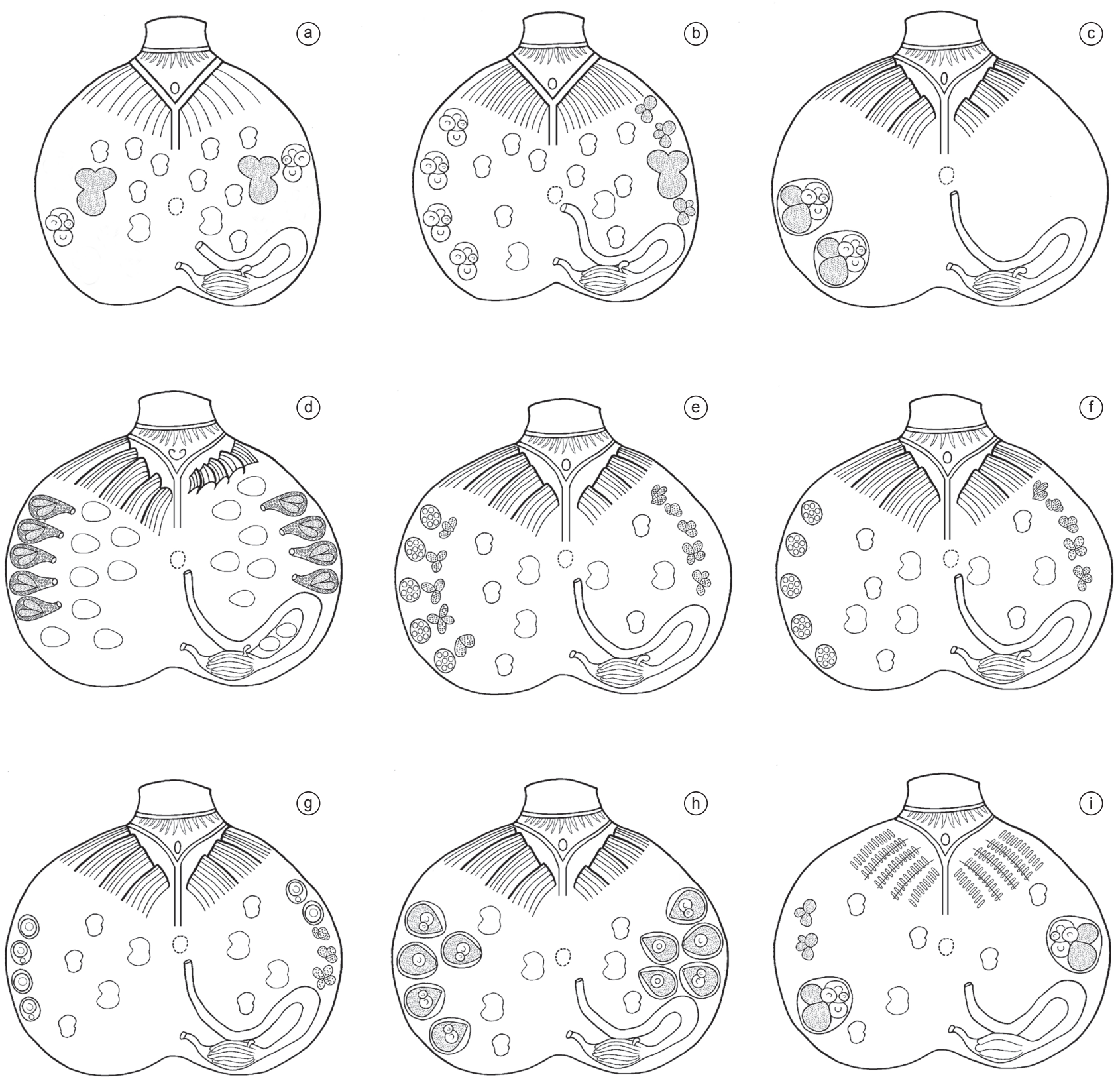

Figure 21. Styelidae. a) Metandrocarpa; b) Alloeocarpa; c) Dextrocarpa; d) Eusynstyela; e) Stolonica; f) Distomus; g) Amphicarpa; h) Monandrocarpa; i) Protostyela.

Figura 21. Styelidae. a) Metandrocarpa; b) Alloeocarpa; c) Dextrocarpa; d) Eusynstyela; e) Stolonica; f) Distomus; g) Amphicarpa; h) Monandrocarpa; i) Protostyela.

colony. Pharynx with less than four folds on each side. Endocarps might be present. Gastric caecum large. Gonads in lines on each side of the endostyle, testes on both sides but ovaries only on the right. Stolonica conglutinata Sluiter, 1915: Mauritania.

Stolonica sabulosa Monniot, 1972: Bermudas, Guadeloupe, Brazil (Bahia)

Distomus Gaertner, 1774 (Figure 21f)

Colonial ascidians with zooids either embedded in a common tunic or linked to a anastomosed network of stolons. Zooids usually in a vertical position, with both siphons opening on the surface of the colony. Pharynx with one to three folds on each side. Endocarps present. Gastric caecum might be present. Gonads along the ventral margin: testes on the left side and ovaries on the right. Brooding inside the right side of the atrial cavity. Distomus hupferi (Michaelsen, 1904): Azores, Senegal.

Distomus rudentiformis (Sluiter, 1915): Senegal, Gambia, Sierra Leone.

Distomus variolosus Gaertner, 1774: U.K.

Amphicarpa Michaelsen, 1922 (Figure 21g)

Colonial ascidians with zooids united by stolons. Zooids usually in a vertical position, with both siphons opening on the surface of 
Rocha, R.M. et al.

the colony. Pharynx with two folds on the left and three on the right, vestigial folds anteriorly. Endocarps present on both sides, on the body wall. Gastric caecum present. Ovary globular with only one mature oocyte. Diagnosis of the genus includes species with a large quantity of small testes on both sides but the only Atlantic species has a small number of gonads, and male follicles only on the left side.

Amphicarpa paucigonas Monniot \& Monniot 1984: Bermuda, Guadeloupe.

\section{Monandrocarpa Michaelsen, 1904 (Figure 21h)}

Colonial ascidians with zooids united by stolons and covered by sediment, both siphons opening on the surface of the colony. Body wall opaque with strong musculature. Pharynx with three or four folds on each side. Endocarps on the body wall, few and large. Alimentary canal large with round stomach; gastric caecum small. Gonads along the ventral margin: ovaries with one or two mature oocytes and without oviduct; one male follicle per gonad and one sperm duct. Gonads develop sequencially. Brooding inside the atrial cavity.

Monandrocarpa stolonifera (Monniot, 1970): Brazil (Piauí, Bahia).

\section{Protostyela Millar, 1954 (Figure 21i)}

Colonial ascidians with small zooids united by stolons, both siphons opening on the surface of the colony. Pharynx with sixteen rows of transverse stigmata and three longitudinal vessels on each side, no folds. Endocarps present on both sides of the body. Gastric caecum absent. The three right gonads aligned parallel to the endostyle; the two anterior male and the posterior hermaphrodite; one hermaphrodite gonad on the left side.

Protostyela heterobranchia Millar, 1954b: Scotland.

Tibitin Monniot, 1983 (Figure 22)

Colonial ascidians with small zooids united by stolons, both siphons opening on the surface of the colony. Pharynx with two folds and four transverse stigmata per row on each side. One endocarp on the body wall, posterior to the gonads, in both sides. Gastric caecum large and curved. Globular ovary with the two male follicles at each side; one sperm duct per gonad.

Tibitin halimedae Monniot, 1983b: Belize, Jamaica, Guadeloupe.

Pyuridae Hartmeyer, 1908 (Table 12)

Solitary ascidians with leathery tunic usually very hard and covered by epibionts. Microscopic spines and scales lining the internal margin of the siphons. A short tunic stalk may be present. Body wall musculature strong with longitudinal fibers radiating from the siphons (Figures 8d, 23h). Endocarps may be present (Figure 19f). Usually one gonad on each side, divided or not into lobes or small sacs (Figure 24). Brooding only in Cratostigma intermedia, in a pouch posterior to the gonad.

\section{Pyura Molina, 1782 (Figure 24a)}

Solitary ascidians of various sizes, covered by a thick leathery tunic. Body globular, oval or elongate. Pharynx with $6-8$ folds on each side and straight stigmata, sometimes curved or spiral at the top of the folds. Dorsal lamina divided into languets. Endocarps might be present on body wall, gonads and intestine (Figure 19f). Stomach tubular and covered by an usually large digestive gland, which also forms small portions on the esophagus. Antler-like calcareous spicules on the intestine wall of some species. Gonads elongate with many small lobes, usually alternating on each side of the gonoducts, the left inside the primary intestinal loop (Figures 23g, 24a).

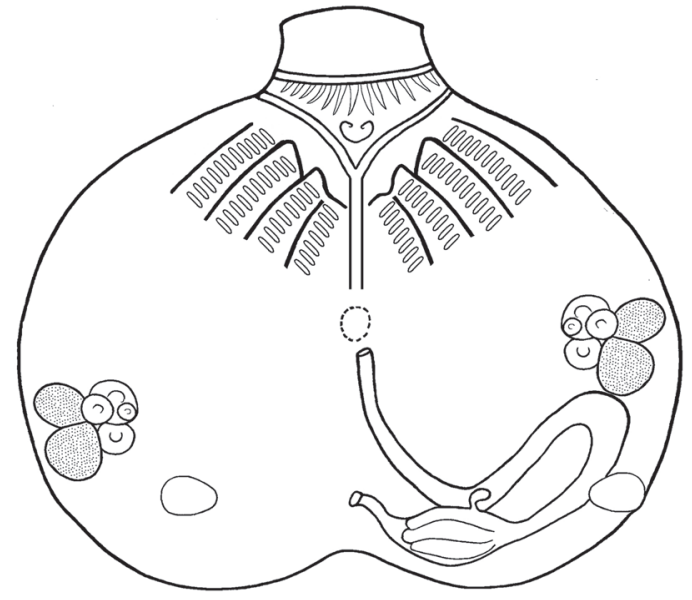

Figure 22. Styelidae. Tibitin.

Figura 22. Styelidae. Tibitin.

Table 12. Key for genera in Pyuridae

Tabela 12. Chave para gêneros em Pyuridae

1. Shape of the dorsal lamina: $\mathrm{L}$ - Divided into languets (Fig 6i);

$\mathrm{M}$ - Continuous membrane (Fig 6h)

2.Shape of the oral tentacles: $\mathrm{R}$ - Ramified (Figure 6a); $\mathrm{S}$ - Simple (Figure 6b)

3. Number of pharyngeal folds

4. Shape/position of the stigmata: $\mathrm{C}$ - Curved, P - Spiral, S - Straight, F - Straight but could form spirals on folds; T - Transverse (Figure 15h)

5. Position of left gonad: 0 - Absent, I - Inside primary intestinal loop (Figure 23g, h); P - Partially inside primary intestinal loop (Figure 19d); A - Anterior to the primary intestinal loop

6. Peculiar characteristics: $\mathrm{C}-$ Calcarious spicules in body wall (Figure 8g); F - Second pharyngeal fold reduced; $\mathrm{S}$ - Spinules on the surface of the tunic or on the rim of the siphons; $\mathrm{P}$ - Papillae on tunic surface; $\mathrm{G}$ - Numerous tubular gonads, parallel to each other and joined in the ventral region (Figure 23i); I - Infundibula; $\mathrm{L}$ - Larvae in a brooding pouch

\begin{tabular}{ccccccc}
\hline $\mathbf{1}$ & $\mathbf{2}$ & $\mathbf{3}$ & $\mathbf{4}$ & $\mathbf{5}$ & $\mathbf{6}$ & Genera \\
\hline $\mathrm{L}$ & $\mathrm{R}$ & $6-8$ & $\mathrm{~S}, \mathrm{~F}$ & $\mathrm{I}$ & $\mathrm{S}$ & Pyura \\
$\mathrm{L}$ & $\mathrm{R}$ & $8-9$ & $\mathrm{~S}$ & $\mathrm{I}$ & $\mathrm{C}$ & Herdmania \\
$\mathrm{L}$ & $\mathrm{R}$ & 6 & $\mathrm{P}$ & $\mathrm{I}$ & $\mathrm{F} / \mathrm{S}$ & Bathypera \\
$\mathrm{L}$ & $\mathrm{R}$ & $6-10$ & $\mathrm{~T}$ & $\mathrm{I}$ & - & Boltenia \\
$\mathrm{L}$ & $\mathrm{R}$ & $7-9$ & $\mathrm{~S}$ & $\mathrm{P}$ & $\mathrm{P} / \mathrm{S} / \mathrm{G}$ & Halocynthia \\
$\mathrm{M}$ & $\mathrm{R}$ & $6-10$ & $\mathrm{~S}$ & $\mathrm{P}$ & $\mathrm{S}$ & Microcosmus \\
$\mathrm{M}$ & $\mathrm{R}$ & $5-6$ & $\mathrm{C}, \mathrm{P}$ & $\mathrm{P}$ & $\mathrm{I}$ & Hartmeyeria \\
$\mathrm{M}$ & $\mathrm{S}$ & $5-6$ & $\mathrm{~F}$ & $\mathrm{~A}^{1}$ & $\mathrm{~F} / \mathrm{I} / \mathrm{L} / \mathrm{S}$ & Cratostigma \\
\hline
\end{tabular}

${ }^{1}$ only C. singularis present a left gonad.

Pyura cadamostoi Monniot, 1994: Cape Verde Pyura discrepans (Suiter, 1898): Cuba, Colombia.

Pyura georgiana (Michaelsen, 1898): Argentina, Antarctic.

Pyura hupferi Michaelsen, 1908: Mauritania, Senegal, Guinea, Sierra Leone 

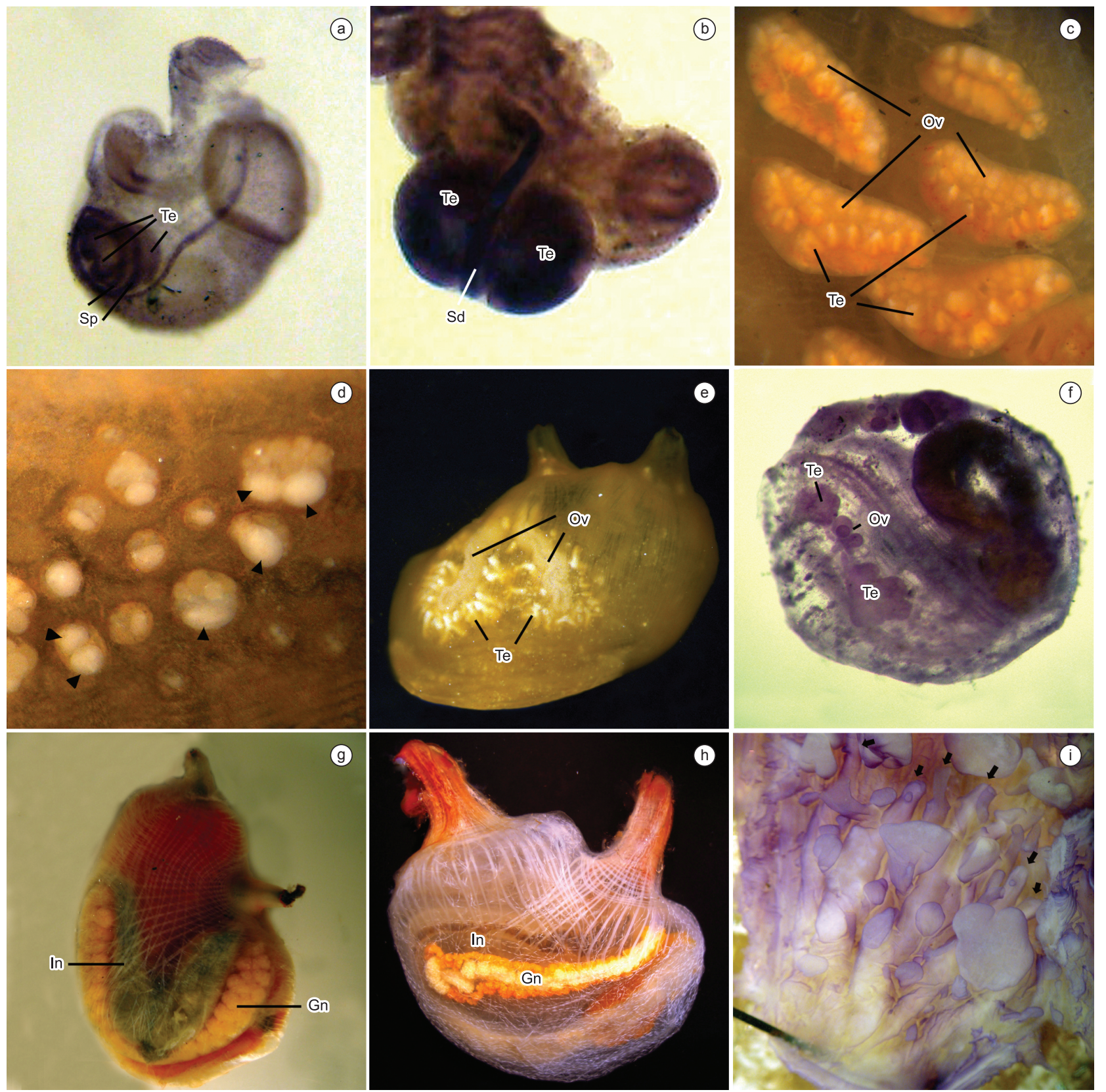

Figure 23. a) Polysyncraton sp. - testis with three follicles (Te) and spiral sperm duct (Sp); b) Lissoclinum sp. - testis with two follicles (Te) and straight sperm duct $(\mathrm{Sd})$; c) Polyandrocarpa anguinea - hermaphroditic gonads covered by a membrane (Ov = ovary; Te $=$ testis); testis with many follicles; d) Eusynstyela sp. - hermaphroditic gonads covered by a membrane; testis with two follicles (arrowheads); e) Styela canopus - elongated hermaphroditic gonads not covered by a membrane; f) Symplegma rubra - hermaphroditic gonads not covered by a membrane; g) Pyura vittata - lobed gonad, left gonad inside the primary intestinal loop ( $\mathrm{Gn}=$ gonad, $\mathrm{In}=$ intestine $)$; h) Herdmania pallida - unlobed gonad, left gonad inside the intestine loop $(\mathrm{Gn}=$ gonad, $\mathrm{In}=$ intestine $)$; i) Halocynthia pyriformis - tubular gonads with their ventral ends connected (arrows showing the free apertures).

Figura 23. a) Polysyncraton sp. - Testículo com três folículos (Te) e espermiduto em espiral (Sp); b) Lissoclinum sp. - Testículos com dois folículos (Te) e espermiduto reto (Sd); c) Polyandrocarpa anguinea - gônadas hermafroditas cobertas por uma membrana (Ov = ovário; Te = testículo); testículo com muitos folículos; d) Eusynstyela sp. - gônadas hermafroditas cobertas por uma membrana; testículos com dois folículos (setas); e) Styela canopus - gônadas hermafroditas alongadas não cobertas por uma membrana; f) Symplegma rubra - gônadas hermafroditas não cobertas por uma membrana; g) Pyura vittata - gônadas lobadas, gônada esquerda dentro da alça intestinal primária $(\mathrm{Gn}=$ gônada, $\mathrm{In}=$ intestino); h) Herdmania pallida - gônada não lobada, gônada esquerda dentro da alça intestinal primária $(\mathrm{Gn}$ = gônada, $\mathrm{In}=$ intestino); i) Halocynthia pyriformis - gônadas tubulares com as extremidades ventrais conectadas (setas indicando aberturas livres).

Pyura legumen (Lesson, 1830): Argentina, Antarctic.

Pyura mariscata Rodrigues, 1966: Brazil (São Paulo).

Pyura microcosmus (Savigny, 1816): U.K., Cape Verde, Senegal.

Pyura millari Rodrigues, 1966: Brazil (São Paulo).

Pyura munita (Van Name, 1902): Bermuda, Belize, Cuba,

Jamaica, Guadeloupe, Martinique, Panama.
Pyura paessleri (Michaelsen, 1900): Falkland Islands. Pyura praia Monniot \& Monniot, 1967: Cape Verde.

Pyura squamulosa (Alder, 1863): Shetland Island, U.K., English Channel.

Pyura stolonifera (Heller, 1878): Strait of Gibraltar, Morocco, Senegal, Namibia, South Africa. 

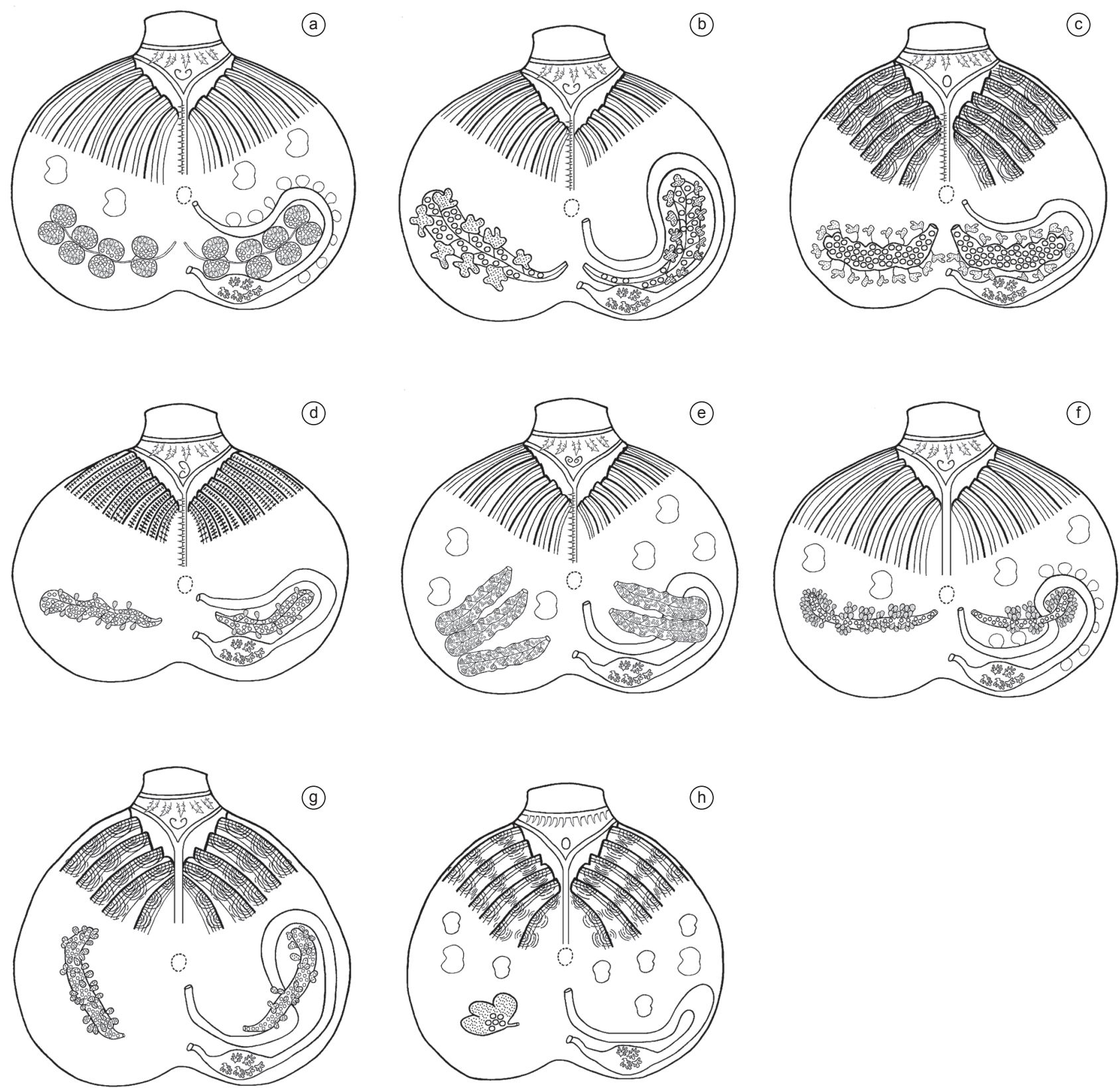

Figure 24. Pyuridae. a) Pyura; b) Herdmania; c) Bathypera; d) Boltenia; e) Halocynthia; f) Microcosmus; g) Hartmeyeria; h) Cratostigma.

Figura 24. Pyuridae. a) Pyura; b) Herdmania; c) Bathypera; d) Boltenia; e) Halocynthia; f) Microcosmus; g) Hartmeyeria; h) Cratostigma.

Pyura stubenrauchi (Michaelsen, 1900): Argentina, Strait of Magellan.

Pyura tessellata (Forbes \& Hanley, 1848): Faroe Islands, Norway, Sweden, U.K., France, Azores, Senegal.

Pyura torpida (Sluiter, 1898): Bermudas, Cuba, Guadeloupe, Martinique, Panama.

Pyura vannamei Monniot, 1994: Guadeloupe, Panama.

Pyura vittata (Stimpson, 1852): U.S. (North Carolina, Florida), Bahamas, Cuba, Jamaica, Puerto Rico, Saint Thomas, Guadeloupe, Martinique, Grenada, Belize, Panama, Colombia, Curaçao, Bonaire, Venezuela, Guyana, Suriname, Brazil (Ceará, Pernambuco, Bahia, São Paulo).
Herdmania Lahille, 1888 (Figure 24b)

Large individuals of around $5 \mathrm{~cm}$ in diameter or more, with a gelatinous tunic. Calcareous needle-like spicules present on the body wall and other organs (Figure 8g). Pharynx with $8-9$ folds on each side and straight stigmata. Dorsal lamina divided into languets. One elongate gonad on each side of the body, compact, not divided in lobes; the left inside the intestinal primary loop (Figure 23h). In living animals, gonads orange colored. Endocarps absent.

Herdmania pallida (Heller, 1878): U.S. (Florida), Cuba, Jamaica, St. Croix, St. Thomas, Guadeloupe, Martinique, Grenada, Belize, Panama, Colombia, Venezuela, Curaçao, Brazil 
(Ceará, Alagoas, Bahia, Rio de Janeiro, São Paulo), Cape Verde, Gabon, South Africa.

Bathypera Michaelsen, 1904 (Figure 24c)

Small solitary ascidians less than $1 \mathrm{~cm}$ long. Tunic covered by regularly disposed papillae with calcareous spicules which bears numerous spinous processes. Pharynx with 6 folds on each side and spiral stigmata forming infundibula on the pharyngeal folds. Dorsal lamina divided into languets. The digestive gland forming one diverticula in each side of the stomach. One gonad on each side of the body, compact, not divided in lobes; the left inside the intestinal loop. Endocarps absent.

Bathypera goreaui Millar \& Goodbody, 1974: Jamaica, Belize, Panama.

\section{Boltenia Savigny, 1816 (Figure 24d)}

Solitary cold water ascidians, covered by a leathery tunic. Oval body, sessile or stalked (B. ovifera). Pharynx with $6-10$ folds on each side and transverse stigmata. Dorsal lamina divided into languets. One gonad on each side of the body, elongate and lobed; the left inside the intestinal loop. Endocarps absent.

Boltenia echinata (Linnaeus, 1767): Greenland, Canada, U.S.

(Maine, Rhode Island), Svalbard/Spitsbergen, Iceland, Norway, Denmark, U.K.

Boltenia ovifera (Linnaeus, 1767): Greenland, Canada, U.S. (Massachusetts, New York).

\section{Halocynthia Verrill and Rathburn, 1879 (Figure 24e)}

Solitary ascidians covered by a leathery tunic with spines and rigid tubercles, usually more conspicuous around the siphons. Pharynx with 7 - 9 folds on each side and longitudinal stigmata. Dorsal lamina divided into languets. Digestive gland composed of longitudinal plications on the proximal part of the stomach near the entrance of the oesophagus, but as a mass of short round-ended secreting tubules on the main part of the stomach. Two to six tubular gonads on each side of the body with their ventral ends connected (Figure 23i). Body wall with endocarps.

Halocynthia microspinosa (Van Name, 1921): Bahamas, Cuba, Jamaica, Guadeloupe, Belize.

Halocynthia pyriformis (Rathke, 1806): Greenland, Davis

Strait, Canada, U.S. (Maine, Massachusetts), Svalbard, Iceland, Faeroe Islands, Norway.

\section{Microcosmus Heller, 1877 (Figure 24f)}

Solitary ascidians with a leathery tunic, usually encrusted by other invertebrates and algae. Siphons usually with long. Pharynx with $6-10$ folds on each side and longitudinal stigmata. Dorsal lamina as a continuous membrane. Stomach with a large digestive gland. One gonad on each side of the body, divided into up to five lobes or not divided at all (Figure 19d); the left gonad crossing the descendent part of the intestine. Endocarps might be present on body wall, gonads and intestine.

Microcosmus anchylodeirus Traustedt, 1883: Cuba, Martinique, Saint Thomas, Brazil (Bahia).

Microcosmus claudicans (Savigny, 1816): Belgium, Scotland,

U.K., English Channel, France, Morocco, Senegal.

Microcosmus exasperatus Heller, 1878: Bermuda, U.S.

(Florida), Cuba, Jamaica, Haiti, Puerto Rico, Saint Thomas,

St. Lucia, Guadeloupe, Martinique, Grenada, Belize, Panama,

Colombia, Aruba, Curaçao, Venezuela, Brazil (Ceará to Santa

Catarina), Senegal, Liberia, Sierra Leone, Ghana, South Africa.

Microcosmus glacialis (Sars, 1859): Greenland, Davis Strait,

Canada, Norway.
Microcosmus helleri Herdman, 1881: U.S. (Florida), Cuba, Jamaica, Puerto Rico, Martinique, Guadeloupe, Antigua, Barbuda, St. Lucia, Curaçao, Brazil (Ceará, Pernambuco, Bahia), Senegal.

Microcosmus oligophyllus Heller, 1878: South Africa.

Microcosmus savignyi Monniot, 1962: Cape Verde.

Microcosmus senegalensis Michaelsen, 1915: Senegal.

\section{Hartmeyeria Ritter, 1913 (Figure 24g)}

Solitary ascidians, less than $2 \mathrm{~cm}$ long, with short siphons inside a tunic crest and a small ramified peduncle. Pharynx with 5-6 folds on each side and spiral stigmata that can form infundibula. Dorsal lamina as a continuous membrane. Digestive gland divided in an anterior and a posterior portion with different aspects. One elongate gonad on each side of the body with male ramified follicles surrounding the ovary; the left gonad crossing the descendent part of the intestine. Endocarps absent. Heart sometimes enlarged at the side of the right gonad (like a molgulid renal vesicle).

Hartmeyeria hupferi (Hartmeyer, 1909): Senegal, Sierra Leone, South Africa.

\section{Cratostigma Monniot \& Monniot, 1961 (Figure 24h)}

Small solitary ascidians up to $4 \mathrm{~cm}$ long. Pharyns with six folds, but the second one usually reduced. Stigmata forming spirals at the apex of the folds but more or less longitudinal at the base. Endocarps present on both sides of the body wall. Oral tentacles unbranched. Hermaphrodite gonad with the testis formed by portions arranged in a half circle around the ovary. Brooding in a pouch posterior to the gonad.

Cratostigma gravellophila (Pérès, 1955): Senegal

Cratostigma intermedia Vazquez \& Ramos-Espla, 1993b: Spain.

Cratostigma singularis (Van Name, 1912): U.S. (Massachusetts

to Connecticut).

\section{Molgulidae Lacaze-Duthiers, 1877 (Table 13)}

Solitary ascidians with thin tunic usually covered by sand attached to thread-like projections. Many species live in soft bottoms. Presence of a renal sac on the right side as the main diagnostic character (Figure 8e). A single elongate gonad on each side, with the testis follicles surrounding all

Table 13. Key for genera in Molgulidae.

Tabela 13. Chave para gêneros em Molgulidae.

1. Pharyngeal folds: $\mathrm{P}$ - Present; 0 - Absent

2. Stigmata: I - Interrupted along the spiral; N - Not interrupted

3. Infundibula aligned antero-posteriorly: $\mathrm{P}$-Present; 0 -Absent

4. Left gonad: I - Inside the primary intestinal loop; O - Outside the primary intestinal loop

5. Peculiar characteristics: D - Direct development in some species; R-Ramified oviduct; $\mathrm{T}$-Transverse vessels anastomosed.

\begin{tabular}{cccccc}
\hline $\mathbf{1}$ & $\mathbf{2}$ & $\mathbf{3}$ & $\mathbf{4}$ & $\mathbf{5}$ & Genera \\
\hline $\mathrm{P}$ & $\mathrm{I}, \mathrm{N}$ & $\mathrm{P}, 0$ & $\mathrm{O}$ & $\mathrm{D}$ & Molgula $^{3}$ \\
0 & $\mathrm{I}, \mathrm{N}$ & $\mathrm{P}$ & $\mathrm{O}$ & $\mathrm{T}$ & Paramolgula \\
0 & $\mathrm{~N}$ & $\mathrm{P}$ & $\mathrm{I}$ & $\mathrm{D}^{1}, \mathrm{R}^{2}$ & Eugyra \\
0 & $\mathrm{~N}$ & 0 & $\mathrm{I}$ & $\mathrm{D}$ & Bostrichobranchus \\
0 & $\mathrm{I}$ & 0 & $\mathrm{O}$ & - & Paraeugyrioides \\
0 & $\mathrm{~N}$ & $\mathrm{P}, 0$ & - & - & Gamaster \\
\hline
\end{tabular}

${ }^{1}$ OnlyE.arenosa $;{ }^{2}$ onlyE.polyducta $;{ }^{3}$ maleandfemalegonadsseparated by the kidney on theright and by the stomach on theleft sidein Molgula retortiformis. 
or part of the ovary. Larvae without statocyte; some species with tailless larvae. Brooding, when present, inside the atrial cavity.

\section{Molgula Forbes \& Hanley, 1848 (Figure 25a)}

Solitary ascidians usually globular, with variable size, from millimeters to centimeters in diameter. Some of the species with sand covering the tunic. Oral tentacles branched. Pharynx with six to eight folds on each side, spiral stigmata forming infundibula in each fold. One gonad on each side of the body; left gonad anterior to the intestinal loop. Some species brood the embryos inside the atrial cavity. Some larvae without the tail.

Molgula amesophleba (Codreanu \& Mack-Fira, 1956): Spain. Molgula antiborealis Millar, 1967: Tristan da Cunha.

Molgula arenata Stimpson, 1852: U.S. (Massachusetts, New York).

Molgula bleizi (Lacaze-Duthiers, 1877): Spain, France.

Molgula braziliensis Millar, 1958: Brazil (Rio de Janeiro, São Paulo).

Molgula celata (Michaelsen, 1914): Gambia, Ghana, Angola. Molgula citrina Alder \& Hancock, 1848: Canada, U.S. (Maine to Connecticut), Spitsbergen/Svalbard, Iceland, Norway, Sweden, Germany, Denmark, Scotland, U.K.

Molgula complanata Alder \& Hancock, 1870: Greenland, Canada, U.S. (Maine, Massachusetts), Brazil? (São Paulo), Spitsbergen/Svalbard, Faeroe Islands, Norway, Scotland, U.K., Azores.

Molgula conchata (Sluiter, 1898b): Senegal, South Africa.

Molgula contorta Sluiter, 1898a: Guadeloupe, Colombia.

Molgula davidi Monniot, 1972: Bermuda.

Molgula dolichentera Millar, 1960b: Nigeria.

Molgula eugyroides Traustedt, 1883: Brazil (Piauí, Bahia).

Molgula falsensis Millar, 1955: South Africa.

Molgula fortuita Monniot \& Monniot, 1984: Guadeloupe,

Brazil (Bahia).

Molgula gigantea (Cunningham, 1871): South Georgia Islands.

Molgula griffithsii (MacLeay, 1825): Canada, Davis Strait,

U.S. (Massachusetts), Spitsbergen/Svalbard, Jan Mayen Islands,

Iceland, Norway, Sweden.

Molgula habanensis Van Name, 1945: Cuba.

Molgula helleri Drasche, 1884: Senegal.

Molgula herdmani Brewin, 1958: Norway.

Molgula kiaeri Hartmeyer 1901: Norway, Skagerrak Strait.

Molgula lutulenta Van Name 1912: U.S., Cuba.

Molgula manhattensis (De Kay, 1843): Canada, U.S. (New

Hampshire to Georgia, Gulf of Mexico), Norway, Sweden, U.K., Spain, Portugal, Morocco.

Molgula monodi Pérès, 1949: Cape Verde, Senegal.

Molgula occidentalis Traustedt, 1883: U.S. (North Carolina, Florida), Belize, Cuba, Jamaica, Puerto Rico, West Indies, Panama, Bonaire, Curaçao, Venezuela, Mauritania, Senegal, Guinea, Ghana.

Molgula occulta Kupffer, 1875: Norway, Skagerrak Strait, North Sea, Sweden, U.K., English Channel, France, Spain, Mauritania, Senegal, Sierra Leone.

Molgula oculata Forbes \& Hanley, 1848: Shetland Islands, U.K., English Channel, France.

Molgula phytophila Monniot, 1970: Brazil (Rio de Janeiro, Paraná, Santa Catarina).

Molgula plana Monniot, 1971: Azores.

Molgula platana Van Name, 1945: Argentina.

Molgula provisionalis Van Name, 1945: Canada, U.S. (Maine).

Molgula pulchra Michaelsen, 1900: Strait of Magellan, Tierra del Fuego, South Georgia Islands.
Molgula pyriformis Herdman, 1881: Brazil (São Paulo), Argentina, Falkland Islands.

Molgula retortiformis Verrill, 1871: Greenland, Canada, U.S.

(Maine to Connecticut), Spitsbergen/Svalbard, Iceland, Norway. Molgula robusta (Van Name, 1912): U.S. (Massachusetts).

Molgula roulei Monniot, 1969: Senegal

Molgula salvadori Monniot, 1970: Brazil (Bahia).

Molgula scutata Millar, 1955: Namibia, South Africa.

Molgula setigera Arnback, 1938: Argentina, Strait of Magellan,

Falkland Islands.

Molgula siphonalis Kiaer, 1896: Greenland, Canada, U.S. (Maine to Connecticut), Spitsbergen/Svalbard, Iceland, Faroe Islands, Norway, Sweden.

Molgula socialis Alder, 1863: Belgium, U.K., France, Spain.

Paramolgula Traustedt, 1835 (Figure 25b)

Solitary ascidians similar to Molgula but without pharyngeal folds which are replaced by wide longitudinal vessels, seven on each side. Body globular or oval with 5 to $30 \mathrm{~cm}$ in diameter. Tunic tough and leathery, specially in young animals. Oral tentacles very branched, 12-16. Short dorsal lamina with smooth margin. Pharynx with very irregular transverse vessels and a large number of small and irregularly distributed infundibula. One gonad in each side of the body; left gonad anterior to the intestinal loop.

Paramolgula gregaria (Lesson, 1830): Argentina, Strait of Magellan, Falkland Islands.

\section{Eugyra Alder and Hancock, 1870 (Figure 25c)}

Small solitary ascidians usually covered by sediment which adheres to thin filaments projecting from the tunic. Pharynx without folds, but with five to seven wide longitudinal vessels on each side of the pharynx and five transverse vessels. Infundibula regularly distributed in antero-posterior lines formed by uninterrupted double spirals. One gonad on each side of the body or only on the left side; left gonad inside or partially inside the primary intestinal loop.

Eugyra arenosa (Alder \& Hancock, 1848): Faroe Islands, Norway, Sweden, Germany, Netherlands, U.K., English Channel.

Eugyra glutinans (Moeller, 1842): Greenland, Canada, Jan Mayen Islands, Iceland, Norway.

Eugyra polyducta (Monniot \& Monniot, 1983): Argentina (Mar del Plata), South Geogia Islands, South Shetland Islands.

\section{Bostrichobranchus Traustedt, 1882 (Figure 25d)}

Solitary ascidians similar to Eugyra, with deep cone-shaped infundibula formed by uninterrupted double spirals, irregularly distributed (Figure 15i). Seven longitudinal vessels on each side of the pharynx and five transverse vessels. One gonad on each side of the body or only on the left side; left gonad inside the primary intestinal loop.

Bostrichobranchus pilularis Verrill, 1871: Canada, U.S. (Maine to Florida).

Bostrichobranchus digonas Abbott, 1951: U.S. (Florida), Brazil (Paraná).

\section{Paraeugyrioides Hartmeyer, 1914 (Figure 25e)}

Solitary ascidian usually covered by sediment. Similar to Bostrichobranchus, with infundibula formed by interrupted double spirals, irregularly distributed. One gonad on each side of the body; left gonad anterior to the intestinal loop, right gonad sometimes absent.

Paraeugyrioides vannamei Monniot, 1970: Brazil (Rio de Janeiro, São Paulo), Argentina. 

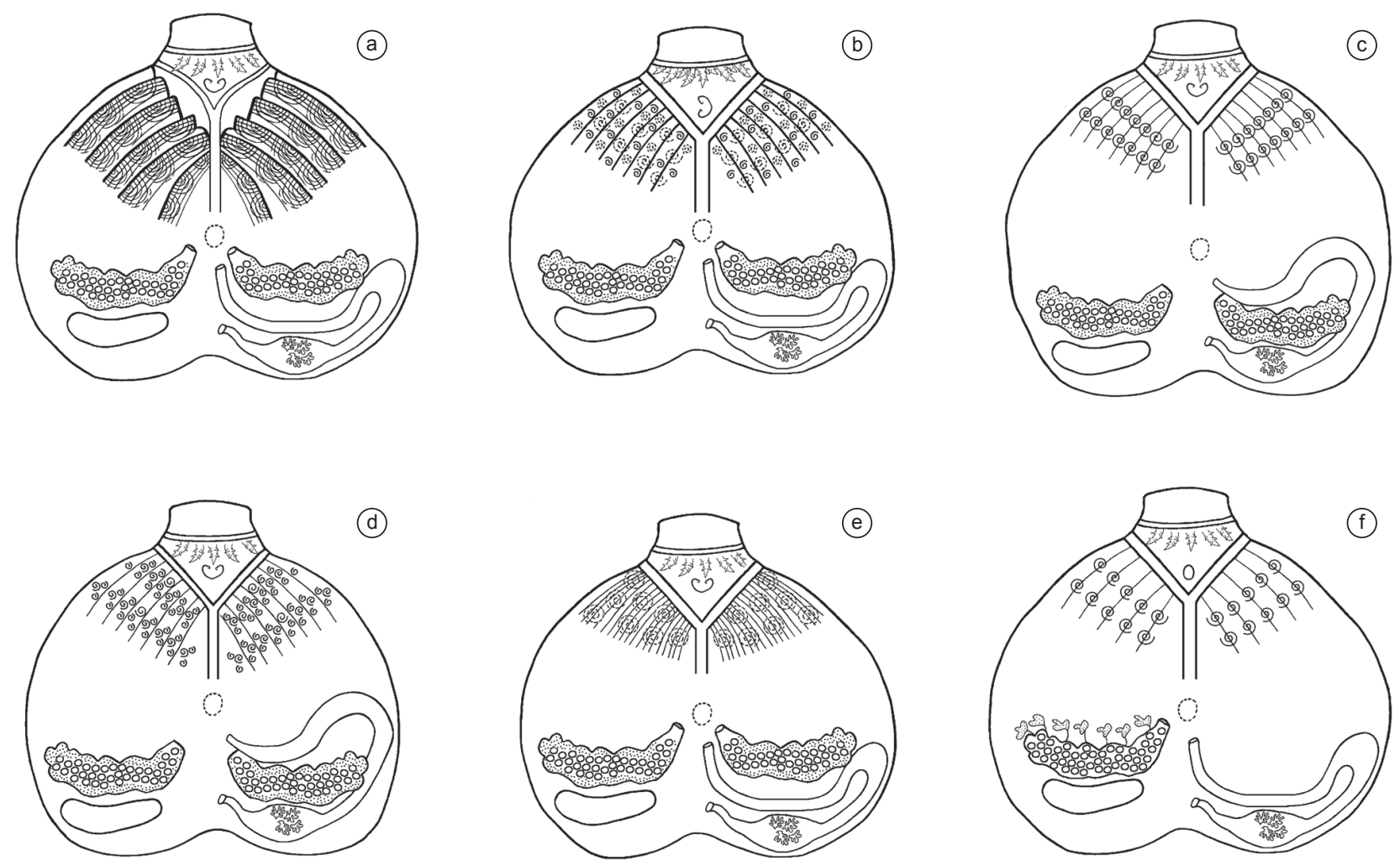

Figure 25. Molgulidae. a) Molgula; b) Paramolgula; c) Eugyra; d) Bostrichobranchus; e) Paraeugyrioides; f) Gamaster.

Figura 25. Molgulidae. a) Molgula; b) Paramolgula; c) Eugyra; d) Bostrichobranchus; e) Paraeugyrioides; f) Gamaster.

\section{Gamaster Pizon, 1896 (Figure 25f)}

Small solitary ascidian, covered by a transparent thin tunic, without sediment. Pharynx with five to seven longitudinal vessels on each side, no folds. Infundibula formed by double spirals. Gonads only on the right side; testis star-like and separated from the ovary.

Gamaster dakarensis Pizon, 1896: France, Spain, Senegal,

Gambia.

Gamaster peresi (Millar, 1957): Sierra Leone.

\section{Acknowledgments}

We would like to thank the students who attended the Tunicate Workshop on Margarita Island, Venezuela (April/2009) and the students who attended the Tunicate Workshop in Bocas del Toro, Panama (June/2009 and June/2011) who tested the keys and Gretchen Lambert who contributed to complement the geographical distribution of many species and with many suggestions. Dr Tito M. da C. Lotufo and an anonymous reviewer also contributed for the improvement of the manuscript. RMR received a research grant from $\mathrm{CNPq}$ and TBZ received a Scientific Initiation scholarship from CNPq. This paper is contribution 1840 of Zoology Department, Universidade Federal do Paraná.

\section{References}

ABBOTT, D.P. 1951. Bostrichobranchus digonas, a new molgulid ascidian from Florida. J. Wash. Acad. Sci. 41:302-307.
AGASSIZ, L. 1850. On the embryology of Ascidia and the characteristic of new species from the shores of Massachusetts. Proc. Am. Assoc. Adv. Sci. 2:157-159.

ALDER, J. 1863. Observations on the British Tunicata with descriptions of several new species. Ann. Mag. Nat. Hist., Ser. 3. 11:153-173.

ALDER, J. \& HANCOCK, A. 1848. Additions to the Mollusca of Northumberland and Durham. Trans. Tyneside Field Club. 1:195-207.

ALDER, J. \& HANCOCK, A. 1870. On the larval state of Molgula with descriptions of several new species of simple ascidians. Ann. Nat. Hist. 6(4):353-368.

ARNBACK, C.L. 1922. Tunicata. In Northern and Arctic invertebrates in the collection of the Swedish State Museum K. Svensk. Vetens. Acad. Handlingar, part 1, v.1, n.2, p.1-62.

ARNBACK, C.L. 1938. Ascidiacea. In Furher zoological results of the Swedish Antarctic expedition 1901-1903 under the direction of Dr. Otto Nordenskjold. Stockholm. 3(4):1-54.

BERRILL, N.J. 1932. Ascidians of the Bermudas. Biol. Bull. 62:77-88.

BJERKAN, P. 1905. Ascidian vom norwegischen Fischereidampfer 'Michael Sars' in den Jahren 1900-1904 gesammelt. Bergens Mus. Aarbog. 5:1-29. http://dx.doi.org/10.2307/1537145

BONNET, N.Y.K. \& ROCHA, R.M. 2011a. The family Ascidiidae Herdman (Tunicata: Ascidiacea) in Bocas del Toro, Panama. Description of six new species. Zootaxa 2864:1-33.

BONNET, N.Y.K. \& ROCHA, R.M. 2011b. The Ascidiidae (Ascidiacea, Tunicata) in coastal Brazil. Zool. Stud. 56:809-825.

BREMENT, E. 1913. Sur deux nouveaux didemnides (Synascidies) du golfe du Lion (Note preliminaire). Bull. Mus. Oceanogr. Monaco. 257:1-7. 
BREWIN, B.J. 1958. Ascidians of New Zealand. Part 11. Ascidians of the Stewart Island region. Trans. Roy. Soc. N.Z. 85(3):439-453.

BRODERIP, W.J. \& SOWERBY, B.G. 1930. Observation on new or interesting Mollusca contained for the most part in the museum of Zoological Society. Zool. J. 5:46-51.

BRUNETTI, R. 2009. Botryllid species (Tunicata, Ascidiacea) from the Mediterranean coast of Israel, with some considerations on the systematics of Botryllinae. Zootaxa. 2289:18-32.

BUGE, E. \& MONNIOT, F. 1972. Nouveaux spicules d'ascidies de l'Yprésien du bassin de Paris et du Toarcien des Deux-Sèvres. Geobios. 5(1):83-90. http://dx.doi.org/10.1016/S0016-6995(72)80007-X

CAULLERY, M. 1914. Sur Diazona geagi. n.sp. ascidie nouvelle de la Guyane et sur la regeneration et le bourgeonement de Diazona. Bull. Soc. Zool. France. 39:204-211.

CODREANU, R. \& MACK-FIRA, V. 1956. Sur une Ascidie nouvelle de la Mer Noire. Ctenicella amesophleba n.sp. confounde avec la Ct. appendiculata (Heller) 1877. C. R. Acad. Sc. 242(22):2665-2668.

CUNNINGHAM, R.O. 1871. Tunicata. In Notes on the Reptilies, Amphibies, Fishes, Mollusca and Crustacea obtained during the voyage of H.M.S. Nassau in the years 1866-1869. Trans. Linn. Soc. London. 27:465-502.

CUVIER, G. 1815. Memoire sur les ascidies et sur leur anatomique. Mem. Mus. Hist. Nat. Paris. 2:10-39.

DAUMEZON, G. 1908. Contribution a l'etude des Synascidies du golfe de Marseille Bull. Sci. France Belgique, Ser. 6. 42(2):269-432.

DELLA VALLE, A. 1881. Nouve contribuzioni alla storia naturale delle ascidie composte del Golfo di Napoli. Att. Accad. Lincei., Ser. 3. 10:431-498.

DE KAY, J.E. 1843. Zoology of New York or the New York fauna. Mollusca. Albany, pt.5.

DIAS, G.M. \& RODRIGUES, S.A. 2004. Didemnum tetrahedrum sp. nov. a new Didemnum (Tunicata: Ascidiacea) species from south-eastern Brazil. J. Mar. Biol. Ass. U.K. 84:1227-1228. http://dx.doi.org/10.1017/ S0025315404010707h

DRASCHE, R. 1883-1884. Die Synascidien der Bucht von Rovigno (Istrien). In Ein Beitrag zur Fauna der Adria (J. Hopkinson). Carl Gerolds Sohn, Wien.

DRASCHE, R. 1884. Ueber einige neue und weniger bekannte aussereuropasche einfache Ascidien. Denkschr. Acad. Wiss. Wien. 48:369-386.

ELLIS, J. \& SOLANDER, D. 1786. The natural history of many curious and uncommon zoophytes collected from various parts of the globe. Benjamin White and Son, London, v.49, p.175-179.

FORBES, E. \& GOODSIR, J. 1841. On Pelonaia a new genus of tunicated mollusks: with description of two species. New Philos. J. Edinburg. 31:29-34.

FORBES, E. \& HANLEY, S.C.T. 1848. A History of the British Molluscs and their Shells. London, v.1, 54p.

GAERTNER, C.F. 1774. Zoophyta quaedam minuta. In Specilegia Zoologica (P.S. Pallas). p.24-41.

GAILL, F. 1972. Repartition du genre Pseudodistoma (Tuniciers): description de deux especies nouvelles. Cah. Biol. Mar. 13:37-47.

GARSTANG, W. 1891. Note on a new and primitive type of compound ascidian. Ann. Mag. Nat. Hist., Ser. 6. 8:265-268.

GIARD, A. 1872. Recherches sur les ascidies composées on synascidies. Arch. Zol. Exp. 1:501-704.

GIARD, A. 1873. Contribution a l'histoire naturelle des synascidies. Arch. Zool. Exp. 2:481-514.

GLEMAREC, M. \& MONNIOT, C. 1966. Repartition des ascidies des fonds meubles de la côte Sud de Bertagne. Can Biol. Mar. 7:343-366.

GOODBODY, I. 1994. The tropical western Atlantic Perophoridae (Ascidiacea): 1. The genus Perophora. Bull. Mar. Sci. 55(1):176-192.

GOODBODY, I. 1996. Pycnoclavella belizeana, a new species of ascidian from the Caribbean. Bull. Mar. Sci. 58(2):590-597.

GOODBODY, I. \& COLE, L. 1987. A new species of Perophora (Ascidiacea) from western Atlantic, including observations on muscle action in related species. Bull. Mar. Sci. 40(2):246-254.
GRAVIER, R. 1955. Ascidies recoltées par le 'President Theodore Tissier' (Campagne de printemps 1951). R. Trav. Inst. Pech. Marit. 19(4):611-631.

HARANT, H. \& VERNIERES, P. 1938. Ascidiae Compositae. Australasian Antarctic Exped. 1911-1914. Sci. Rept., ser. C, Zool. and Bot. 3(5):1-13.

HARTMEYER, R. 1901. Holosome Ascidien (Ascidiacea Holosomata). Meerfauna. Bergen. 1:19-63.

HARTMEYER, R. 1903. Die Ascidien der Arktis. In Fauna Arct. 3(2): 93-412.

HARTMEYER, R. 1906. Ein Beitrag zur Kenntnis der japanischen Ascidienfauna. Zool. Anz. 31:1-30.

HARTMEYER, R. 1909. Ascidien (continuation of work by Seeliger). In Klassen und Ordnungen des Tier-reichs (H.G. Bronn). Leipzig. 81-98(supl. 3):1281-1773.

HARTMEYER, R. 1912. Die ascidien der Deutschen Tiefsee-Expedition. Deutschen Tiefsee-Expedition. 16:225-392.

HARTMEYER, R. 1913. Tunicata. In Schaltze, L. Zoologische und Antropologische Ergebnisse einer For schungsreise im Westlichen und Zentrelen Sudafrica. Jene. 5:125-144.

HELLER, C. 1874. Untertsuchungen uber die Tunicaten des Adriatischen Meeres. Denkschr. Akad. Wien. 34:1-20.

HELLER, C. 1875. Untertsuchungen uber die Tunicaten des Adriatischen Meeres. Denkschr. Akad. Wien. 36:107-125.

HELLER, C. 1877. Untersuchungen uber die Tunicaten des Adriatischen und Mittelmeeres. Denkschr. Acad. Wien. 37:241-275.

HELLER, C. 1878. Beitrage zur nahern Kenntniss der Tunicaten Sitzber. Denkschr. Acad. Wien. 77(1):2-28.

HERDMAN, W.A. 1880. Preliminary report on the Tunicata of the Challenger expedition. Ascidiidae. Proc. R. Soc. Edin.10(1):458-472.

HERDMAN, W.A. 1881. Preliminary report on the Tunicata of the Challenger expedition. Cynthiidae. Proc. R. Soc. Edin. 11(3):52-88.

HERDMAN, W.A. 1882. Report on the Tunicata collected during the voyage of H.M.S. Challenger during the years 1873-1876. part 1. Ascidiae Simplices. Zool. Chall. Exp. 6(17):1-296.

HERDMAN, W.A. 1884. Report upon the Tunicata dredged during the cruises of H.M.S. 'Porcupine' and 'Lightning' in the summer of 1868 and 1870. Trans. R. Soc. Edin. 32(2):219-231.

HERDMAN, W.A. 1886. Report on the Tunicata collected during the years 1873-1876. Part 2. Ascidiae Compositae. Zool. Chall. Exp. 14(38):1-425.

HERDMAN, W.A. 1891. A revised classification of the Tunicata with definition of the orders, suborders, families, subfamilies, and genera, and analytical keys to the species. J. Linn. Soc. Lond. Zool. 23:558-652. http://dx.doi.org/10.1111/j.1096-3642.1891.tb02403.x

HERDMAN, W.A. 1902. Tunicata. In Report on the collections of natural history made in the Antarctic regions during the voyage of the Southern Cross (British Museum (Natural History) \& E.R. Lankester). London. 6:190-200.

HIROSE, E., OKA, A.T. \& HIROSE, M. 2009. Two new species of photosymbiotic ascidians of the genus Diplosoma from the Ryukyu Archipelago, with partial sequences of the COI gene. Zool. Sci. 26:362368. PMid:19715507. http://dx.doi.org/10.2108/zsj.26.362

KIAER, J. 1893. Oversigt over Norgen Ascidiae Simplices Vid. Selsk. Forh. Christian. 9:1-105.

KIAER, J. 1896. Fortegnelse over Norgen Ascyidiae Simplices. Norska Nordhavs-Exped. part. 3. 7(23):1-23.

KOTT, P. 1952. Observation on compound ascidian of the Plymouth area with description of two species. J. Mar. Biol. Assoc. U.K. 31(1):65-83. http:// dx.doi.org/10.1017/S0025315400003696

KOTT, P. 1985. The Australian Ascidiacea. Part I: Phlebobranchia and Stolodibranchia. Mem. Queensl. Mus. 23:1-440.

KOTT, P. 1990. The Australian Ascidiacea. Part II: Aplousobranchia (1). Mem. Queensl. Mus. 29:1-298. 
KOTT, P. 1992. The Australian Ascidiacea. Part III: Aplousobranchia (2). Mem. Queensl. Mus. 32:375-655.

KOTT, P. 2001. The Australian Ascidiacea. Part IV: Aplousobranchia (3), Didemnidae. Mem. Queensl. Mus. 47:1-410.

KOTT, P. 2002. A complex didemnid ascidian from Whangamata, New Zealand. J. Mar. Biol. Ass. U.K. 82:625-628. http://dx.doi.org/10.1017/ S0025315402005970

KOWALEVSKY, A.O. 1874. Ueber die Knospung der Ascidien. Arch. F. Mikr. Anat. 10:441-470. http://dx.doi.org/10.1007/BF02960331

KUPFFER, C.W. 1875. Tunicata. Jahr. Komm. Wiss. Untersuchung deutschen. Meere in Kiel 2:197-228.

LACAZE-DUTHIERS, H. 1877. Histoire des ascidies simples des côtes de France. Deuxieme partie. Arch. Zol. Exp. Gen. 6:457-673.

LACAZE-DUTHIERS, H. \& DELAGE, Y. 1892. Faune des Cynthiadées de Roscoff et côtes de Belge. Mem. Pres. Acad. France. Ser. 2. 45:1-319.

LAFARGUE, F. 1968. Les peuplements sessiles de l'archipel de Glenan. 2. Les Didemnidae. Systematique. Ecologie Vie Milieu A. 19(2):353-446.

LAFARGUE, F. \& DUCLAUX, G. 1979. Premier example en Atlantique tropical d'une association symbiotiqe entre une ascidie Didemnidae et une cyanophyce chroococcale: Trididemnum cyanophorum nov.sp. et Synechocystis trididemni nov.sp. Ann. Inst. Oceanogr. Paris. 55:163-184.

LESUEUR, C.A. 1823. Descriptions of several new species of Ascidia. J. Acad. Nat. Sci. Philadelphia 3:2-8.

LESSON, R.P. 1830. Centuria Zoologique. Paris.

LINNAEUS, C. 1767. Systema Naturae. 12th ed. Stockholm.

LOTUFO, T.M.C. \& DIAS, G.M. 2007. Didemnum galacteum, a new species of white didemnid (Chordata: Ascidiacea: Didemnidae) from Brazil. Proc. Biol. Soc. Washington. 120(2):137-142. http://dx.doi.org/10.2988/0006324X(2007)120[137:DGANSO]2.0.CO;2

MAcLEAY, W.S. 1825. Anatomical observations on the natural group of the Tunicata, with the description of three species collected in Fox Channel. Trans. Linn. Soc. London. 14:527-555.

MEDIONI, A. 1970. Ascidies du benthos rocheux Banyuls-sur-Mer. Didemnidae (Ascidies composées). Vie Milieu. A 21(1):25-48.

MICHAELSEN, W. 1898. Vorläufige Mittheilung uber einige Tunicaten aus dem magalhaenischen Gebiet, sowie von Süd-Georgien. Zool. Anz. 21:363-371.

MICHAELSEN, W. 1900. Die holosomen Ascidien des Magalhaenisch-Sudgeorgischen Gebiet. Zoologica. 12(31):1-148.

MICHAELSEN, W. 1904. Revision der compositen Styeliden oder Polyzoen. Jahrb. Wiss. Anst. Hamburg. 21(suppl. 2):1-124.

MICHAELSEN, W. 1907. Tunicaten. Ergebnisse der Hamburger Magalhaensischen Sammedreise 1892-1893. Hamburg. 1:1-84.

MICHAELSEN, W. 1908. Die Pyuriden (Halocynthiiden) des Naturhistorischen Museums zu Hamburg. Jahrb. Wiss. Anst. Hamburg. 25(suppl. 2):227-287.

MICHAELSEN, W. 1914. Ueber einigke westafrikanische ascidien. Zool. Anz. 43:423-432.

MICHAELSEN, W. 1915. Tunicata. Beitrage zur Kenntnis der Meeresfauna Westafrikas. Hamburg. 1:312-518.

MICHAELSEN, W. 1919. Ascidie Ptychobranhiae und Diktyobranchiae des Roten Meeres. Denkschr. Akad. Wiss. Wien. 95(10):1-120.

MICHAELSEN, W. 1923. Neue und altbekannte Ascidien aus dem Reichsmuseum zu Stockholm. Mitt. Zol. Mus. Hamburg. 40:1-60.

MICHAELSEN, W. 1924. Ascidiae Krikobranchiae von Neuseeland, den Chatham und den Auckland. Inseln Vid. Meddel. Dansk Nat. Foren. 77:263-434.

MICHAELSEN, W. 1934. The ascidians of the Cape Province of South Africa. Trans. Roy. Soc. South Africa. 22:129-163. http://dx.doi. org/10.1080/00359193409519335

MILLAR, R.H. 1953. On the collection of ascidians from the Gold Coast. Proc. Zool. Soc. London. 123(2):277-325. http://dx.doi. org/10.1111/j.1096-3642.1953.tb00176.x
MILLAR, R.H. 1954a. Pseudodistoma africanum sp. n. a new compound ascidian from south Africa. Ann. Mag. Nat. Hist. 12(7):128-132. http:// dx.doi.org/10.1080/00222935408651705

MILLAR, R.H. 1954b. Protostyela heterobranchia n. gen. n. sp. a styelid ascidian from the Scottish west coast. J. Mar. Biol. Ass. U.K. 33:677-679. http://dx.doi.org/10.1017/S0025315400026941

MILLAR, R.H. 1955. On a collection of ascidians from South Africa. Proc. Linn. Soc. Lond. 125(1):169-221.

MILLAR, R.H. 1957. Further notes on ascidians from Sierra Leone. Ann. Mag. Nat. Hist., Ser. 12. 10:369-377.

MILLAR, R.H. 1958. Some ascidians from Brazil. Ann. Mag. Nat. Hist. 13(1):497-514. http://dx.doi.org/10.1080/00222935808650975

MILLAR, R.H. 1960a. Ascidiacea. Discovery Rep. 30:1-160.

MILLAR, R.H. 1960b. Molgula dolichentera a new species of ascidian from the eastern Nigeria. Ann. Mag. Nat. Hist., Ser.13. 3:129.

MILLAR, R.H. 1961. Euherdmania vitrea, a new species of ascidian from Brazil. Ann. Mag. Nat. Hist. 4:143-147. http://dx.doi. org/10.1080/00222936108655793

MILLAR, R.H. 1962. Further description of South African ascidians. Ann. South Afr. Mus. 46(7):113-221.

MILLAR, R.H. 1967. Ascidians from the Tristan da Cunha group of islands Results of the Norwegian sci. exp. to Tristan da Cunha. 1937-38. 53:1-15.

MILLAR, R.H. 1968. A collection of ascidian from the Vema Seamount. Trans. Roy. Soc. S. Afr. 38:1-21. http://dx.doi.org/10.1080/00359196809519069

MILLAR, R.H. 1977. Ascidians (Tunicata: Ascidiacea) from the northern and northern-eastern Brazilian shelf. J. Nat. Hist. 11(2):169-223. http:// dx.doi.org/10.1080/00222937700770131

MILLAR, R.H. 1978. Ascidians from the Guyana shelf Netherlands. J. Sea Res. 12(1):99-106. http://dx.doi.org/10.1016/0077-7579(78)90027-3

MILLAR, R.H. \& GOODBODY, I. 1974. New species of ascidians from the West Indies. Stud. Fauna. Curaçao Carib. Isl. 45:142-161.

MILNE-EDWARDS, H. 1841. Observations sur les ascidies composes des côtes de la Manche. Mém. Acad. Sci. Inst. Fr. 18:217-326.

MOELLER, H.P.C. 1842. Index molluscorum Groenlandiae. Naturh. Tidsskr. 4:76-97.

MONNIOT, C. 1962. Les Microcosmus des côtes de France. Vie Milieu. 13:397-492.

MONNIOT, C. 1969. Sur une collection d'ascidies de Dakar (Phlebobranches et Stolidobranches). Bull. Mus. Natn. Hist. Nat., Ser. 2. 41:622-654.

MONNIOT, C. 1970. Ascidies phlebobranches et stolidobranches. In Campagne de la Calypso au large des cotes de l'Amerique du Sud. Ann. Inst. oceanogr. 47:33-59.

MONNIOT, C. 1971. Quelques ascidies infralitorales de Sao Miguel (Açores) Bull. Mus. natn. Hist. Nat, Ser. 2. 42(6):1200-1207.

MONNIOT, C. 1972. Ascidies stolidobranches des Bermudes. Bull. Mus. natn. Hist. Nat., Ser. 3. Zool. 43(57):617-643.

MONNIOT, C. 1974. Ascidies littorales et bathyales recoltees au cours de la campagne Biacores: Phlebobranches et Stolidobranches. Bull. Mus. natn. Hist. Nat., Ser. 3. Zool. 173(251):1327-1352.

MONNIOT, C. 1983a. Ascidies littorales de Guadeloupe 2. Phlebobranches. Bull. Mus. natn. Hist. Nat., Ser. 4. A. 5(1):51-71.

MONNIOT, C. 1983b. Ascidies littorales de Guadeloupe. 4. Styelidae. Bull. Mus. natn. Hist. Nat., Ser. 4, A. 5 (2):423-456.

MONNIOT, C. 1994. Pyura lignosa (s.s.), a Pacific ascidian from Central America, with descriptions of species confused under this name. Zool. J. Lin. Soc. 110:41-51. http://dx.doi.org/10.1111/j.1096-3642.1994. tb01470.x

MONNIOT, C. \& MONNIOT, F. 1967. Campagne de la Calypso aux Iles du Cap Vert (1959). Tuniciers benthiques. Ann. l'Inst. Oceanogr, Paris. 45(2):3-19.

MONNIOT, C. \& MONNIOT, F. 1972. Clé mondiale des genres d’Ascidies. Arch. Zool. Expér. Génér. 113(3):311-367. 
MONNIOT, C. \& MONNIOT, F. 1983. Ascidies antarctiques et subantarctiques: morphologie et biogeography. Mem. Mus. natn. Hist. Nat., ser. A., Zool. 125:1-168.

MONNIOT, C. \& MONNIOT, F. 1984. Ascidies littorales de Guadeloupe. 7. Espèces nouvelles et complementaries a l'inventaire. Bull. Mus. natn. Hist. Nat., Ser. 4, A. 6(3):567-582.

MONNIOT, C. \& MONNIOT, F. 1987. Les ascidies de Polynesie française. Mem. Mus. natl. Hist. Nat., Ser. A. 136:1-155.

MONNIOT, C. \& MONNIOT, F. 1994a. Additions to the inventory of eastern tropical Atlantic ascidians; arrival of cosmopolitan species. Bull. Mar. Sci. 54(1):71-93.

MONNIOT, C. \& MONNIOT, F. 1994b. Ascidians collected in the Weddell Sea by the RV 'Polarstern' (EPOS cruise leg 3). Bull. Mus. natn. Hist. nat., Ser. 4, A. 16(1):13-37.

MONNIOT, C., MONNIOT, F. \& LABOUTE, P. 1991. Coral Reef Ascidians of New Caledonia. Orstom, Paris.

MONNIOT, F. 1964. Polycarpa ärnbäckae n. sp. Styelidae interstitielle des sables conquilliers de la côte de Suède. Cah. Biol. Mar. 5(1):27-31.

MONNIOT, F. 1969. Sur une collection d'ascidies composes de Dakar. Bull. Mus. natn. Hist. nat., Ser. 2. 41(2):246-247.

MONNIOT, F. 1972. Ascidies aplousobranches des Bermudes. Polyclinidae et Polycitoridae. Bull. Mus. natn. Hist. nat., Ser. 3. 82:949-962.

MONNIOT, F. 1974. Ascidies littorales et bathyales recoltées au cours de la campagne Biaçores: Aplousobranches. Bull. Mus. natn. Hist. nat., Ser. 3. 173(251):1287-1325.

MONNIOT, F. 1983a. Ascidies littorales de Guadeloupe. 1. Didemnidae. Bull. Mus. Natn. Hist. Nat., Ser. 4 A. 5(1): 3-49.

MONNIOT, F. 1983b. Ascidies littorales de Guadeloupe 3. Polyclinidae. Bull. Mus. Natn. Hist. Nat., Ser. 4, A. 5(2):413-422.

MONNIOT, F. 1983c. Ascidies littorales de Guadeloupe 5. Polycitoridae. Bull. Mus. Natn. Hist. Nat., Ser. 4, A. 4:999-1019.

MONNIOT, F. 1984. Ascidies littorales de Guadeloupe 8. Questions de systématique évolutive posées par les Didemnidae. Bull. Mus. Natn. Hist. Nat., Ser. 4, A. 6(4):885-905.

MONNIOT, C., MONNIOT, F. \& LEUNG TACK, K.D. 1987. Une nouvelle espèce d'Ascidie du Senegal: Polycarpa longitubis n.sp. (Styelidae). Bull. Inst. fondam. Afr. Noire. 45(3-4):308-315.

MÜELLER, O.F. 1776. Zoologiae Danicae. Prodromus, Copenhagen, p.224-226.

NEWELL, I.M. 1970. Construction and use of tabular keys. Pacif. Insects. 12(1):25-37

OKA, A. 1927. Zur kenntnis der japanishen Botryllidae (Vorlaufige Mitteilung). Proc. Imp. Acad. 3:607-609.

OKA, A.T., SUETSUGU, M. \& HIROSE, E. 2005. Two new species of Diplosoma (Ascidiacea: Didemnidae), bearing prokaryotic algae Prochloron from Okinauajima (Ryukyu Archipelago, Japan). Zool. Sci. 22:367-374. PMid:15795500. http://dx.doi.org/10.2108/zsj.22.367

OKUIAMA, M. \& SAITO, Y. 2001. Studies on the structure of the brooding organs of two Botryllid ascidians, Botryllus delicatus and Botryllus sexiens. Zool. Sci.18:397-404. http://dx.doi.org/10.2108/zsj.18.397

PALLAS, P.S. 1766. Elenchus zoophytorum. Frankfurt, p.18-451.

PÉRÈS, J.M. 1948. Sur une collection d'Ascidies de la zone intercotidale de Dakar. Bull. Mus. natl. Hist. Nat., Ser. 2. 20(1):87-95.

PÉRÈS, J.M. 1949. Contribuition a l'étude des ascidies de la côte occidentale d'Afrique. Bull. Inst. franç. Afr. Noire. 11(1-2):159-207.

PÉRÈS, J.M. 1951. Nouvelle contribution a l'étude des ascidies de la côte occidentale d'Afrique. Bull. Inst. franç. Afr. Noire. 13:1051-1071.

PÉRÈS, J.M. 1955. Sur une ascidie nouvelle recoltee dans la gravelle de Castiglione (Heterostigma gravellophia $\mathrm{n} . \mathrm{sp}$.). Bull. St. Aquicult. Peche Castiglion, N. Ser. 7:299-303.

PÉREZ-PORTELA, R., DURAN, S., PALACÍN, C. \& TURON, X. 2007. The genus Pycnoclavella (Ascidiacea) in the Atlanto-Mediterranean region: a combined molecular and morphological approach. Invert. Syst. 21:187-205. http://dx.doi.org/10.1071/IS06015
PIZON, A. 1896. Description d'un nouveau genre d'Ascidies simples de la famille des Molgulidae, Gamaster dakarensis. C. R. Acad. Sci. 122:13451347.

RATHKE, J. 1806. Tunicata. Zool. Danica. 4:1-41.

REDIKORZEV, V. 1907. Die ascidien der russischen Polar expedition 19001903. Zool. Anz. 31(17-18):521-525.

RENIER, S.A. 1804. Prospetto della classe dei vermi. Padua, p.15-27.

RITTER, W.E. 1903. The structure and affinities of Herdmania claviformis, the type of a new genus and family of ascidians. Mark Anniv. Volume. 12:237261.

RITTER, W.E. \& FORSYTH, R.H. 1917. Ascidian of the littoral zone of southern California. Univ. California Publ. Zool. 16:439-512.

ROCHA, R.M. 2002. Trididemnum maragogi sp. nov. (Ascidiacea. Didemnidae) from Alagoas, Northeastern Brasil. Revta bras. Zool. 19(4):1105-1110.

ROCHA, R.M. \& BONNET, N.Y.K. 2009. Eudistoma clavatum sp. nov. (Tunicata: Ascidiacea: Polycitoridae) from Brazil. Brasil. Mar. Biodiv. Rec. 2(e3):1-4.

ROCHA, R.M. \& COSTA, L.V.G. 2005. Ascidians (Urochordata: Ascidiacea) from Arraial do Cabo, Rio de Janeiro, Brazil. Inheringia, Ser. Zool. 95(1):57-64.

ROCHA, R.M. \& MONNIOT, F. 1993. Didemnum rodriguesi sp. nov., a new didemnid tunicate common to Southern Brazil and New Caledonia. Ann. Inst. oceanogr., Paris. 69(2):261-265.

ROCHA, R.M. \& MORENO, T.R. 2000. Ascidians associated with Eudistoma carolinense Van Name. 1945. With description of a new species of Polycarpa. Ophelia. 52(1):9-16.

RODRIGUES, S.A. 1962. Algumas ascídias do litoral Sul do Brasil. Bol. Fac. Filos. Ciênc. Univ. S. Paulo, Zool. 24:193-215.

RODRIGUES, S.A. 1966. Notes on Brazilian Ascidians. 1. Pap. Avulsos Dept. Zool. São Paulo. 19(8):95-115.

SAITO, Y. \& OKUYAMA, M. 2003. Studies on Japanese botryllid ascidians. IV. A new species of the genus Botryllus with a unique colony shape, from the vicinity of Shimoda. Zool. Sci. 20:1153-1161. PMid:14578576. http://dx.doi.org/10.2108/zsj.20.1153

SANAMYAN, K. \& GLEASON, D.F. 2009. Ascidians of the genus Aplidium collected on shallow hard-bottom reefs of coastal Georgia (Atlantic coast of North America U.S.A.). Zootaxa. 2066:50-58.

SANAMYAN, K., GLEASON, D.F. \& SANAMYAN, N. 2009. A new species of Polyzoa (Ascidiacea: Styelidae) from the Atlantic coast of North America, U.S.A. Zootaxa. 2088:65-68.

SARS, M. 1851. Beretning om en i Sommeren 1849 foretagen zoologisk Reise i Lofoten og Fimarken. Nyt Mag. Naturvidensk. 6:121-211.

SARS, M. 1859. Bidrag til en skildering af den arktiske molluskfauna ved Norges nordlige. Kyst. Forh. Vidensk. Selsk., Christiania. 1858:34-87.

SAVIGNY, J.C. 1816. Recherches anatomiques sur les ascidies composées et les ascidies simples. Système de la classe des ascidies. In Mémoires sur les Animaux sans Vertèbres (Dufour, G). Paris, part 2.

SHENKAR, N., GITTENBERGER, A., LAMBERT, G., RIUS, M., ROCHA, R.M. \& SWALLA, B.J. 2010. World Ascidiacea Database. http://www. marinespecies.org/ascidiacea (último acesso em 20/11/2011).

SLUITER, C.P. 1890. Die Evertebraten aus der Sammlung des Koniglichen natur wissenschaftlichen Vereins in Nederlandisch-Indien in Batavia. Zugleich eine Skizze der Fauna des neuen Arten. Ascidiae simplices Natuurk. Tijdschr. Ned. Indie. 50:329-348.

SLUITER, C.P. 1895. Tunicaten. In Semon. R. Zoologische Forschungsreisen in Australien und den malagischen Archipel Denkschr. Gesellsch. Jena. 8:163-186.

SLUITER, C.P. 1898a. Tuniciers récueillis en 1896 par La Chazalie dans la Mers des Antilles. Mem. Soc. Zool. France. 11:5-34.

SLUITER, C.P. 1898b. Beitrage zur kenntnis der fauna von Sud-Afrika. Zool. Jahrb. Syst. 11:1-64.

SLUITER, C.P. 1900. Tunicaten aus dem Stillen Ozean Zool. Jahrb. Syst. 13:1-35. 
SLUITER, C.P. 1904. Die tunicaten der Siboga-Expedition. Part I - Die socialen und holosomen ascidien. Siboga Exped. 56:1-126.

SLUITER, C.P. 1906. Tuniciers. In Expedition Antarctique Française (1903-1905). Paris. Doc. Scientif. 1-50.

SLUITER, C.P. 1912. Les ascidies de l'Expedition Antarctique Française du 'Pourquoi-pas?' comandée par le Dr. Charcot 1908-1909. Bull. Mus. Natl. Hist. Nat., Paris. 18(7):452-460.

SLUITER, C.P. 1915. Einige neue ascidien von der West-Kuste Afrikas. Tijdschr. Nederlandsche Dierk. Ver., Ser. 2, 14:37-57.

SLUITER, C.P. 1927. Les ascidies de la cote Atlantique du Maroc. Bull. Soc. Sci. Nat. Maroc. 7:50-99.

SLUITER, C.P. 1932. Die von Dr. L.Kohl-Larsen gesammelten Ascidien von Sud-Georgien und der Stewart Insel. Senckenbergiana. 14:1-19.

STIMPSON, W. 1852. Several new ascidians from the coast of the United States. Proc. Boston Soc. Nat. Hist. 4:228-232.

STIMPSON, W. 1855. Descriptions of some of new marine invertebrata from Chinese and Japanense seas. Proc. Acad. Nat. Sci. 7:375-384.

TOKIOKA, T. 1953. Ascidians of Sagami Bay Iwanami Shoten. Tokyo.

TOKIOKA, T. 1954. Contribution to Japanese ascidian fauna. 7. Invertebrate fauna of the intertidal zone of the Tokara Islands. 7. Ascidians. Publ. Seto Mar. Biol. Lab. 3(3):239-264.

TRAUSTEDT, M.P.A. 1882. Vestindiske Ascidiae Simplices. Forsie Afdeling. Phallusiadae. Vid. Meddel. Nat. For. Kjobenhavn. Ann. 1881:257-288.

TRAUSTEDT, M.P.A. 1883. Vestindiske Ascidiae Simplices. Anden Afdeling. Molgulidae og Cynthiadae. Vid. Meddel. Nat. For. Kjobenhavn. Ann. 1882:108-136.

TRAUSTEDT, M.P.A. 1886. Kara Havets Spunge (Ascidiae Simplices). Dijmphna Togtets Zool.-Bot. Udbytte, p.419-437.

VAN BENEDEN, P.J. 1846. Recherches sur l'embriogenie. l'anatomie et la physiologie des ascidies simples. Mem. Acad. R. Belge. 20(1):1-66.
VAN NAME, W.G. 1902. The ascidians of the Bermuda Islands. Trans. Connecticut Acad. Sci. 11:325-412.

VAN NAME, W.G. 1910. Compound ascidians of the coasts of New England and neighboring British provinces. Proc. Boston Soc. Nat. Hist. 34:339-424.

VAN NAME, W.G. 1912. Simple ascidians of the coasts of New England and neighboring British provinces. Proc. Boston Soc. Nat. Hist. 34:439-619.

VAN NAME, W.G. 1921. Ascidians of the West Indian region and south eastern United States. Bull. Am. Mus. Nat. Hist. 44:283-494.

VAN NAME, W.G. 1924. Ascidians from Curacao. Bijdr. Dierkunde 23:23-32.

VAN NAME, W.G. 1931. New North and South American ascidians. Bull. Amer. Mus. Nat. Hist. 61:207-225.

VAN NAME, W.G. 1945. The North and South American ascidians. Bull. Am. Mus. Nat. Hist. 84:1-476.

VAZQUEZ, E. 1993. Diplosoma lafargueae n.sp., a new species of the Didemnidae family (compound ascidians) in the Iberian Atlantic coast. Vie Milieu. 43(2-3):173-175.

VAZQUEZ, E. 1994. A new species of the genus Aplidium Savigny. 1816 (Ascidiacea, Polyclinidae) from the Spanish Atlantic coast. Sarsia. 79:53-57.

VAZQUEZ, E. \& RAMOS-ESPLA, A. 1993a. Eudistoma roseum n.sp. (Ascidiacea. Polycitoridae) from the Iberian Atlantic Coast. Ophelia. 37(2):95-100.

VAZQUEZ, E. \& RAMOS-ESPLA, A. 1993b. Cratostigma intermedia n.sp. (Ascidiacea. Pyuridae), une nouvelle espèce des côtes atlantiques ibériques. Bull. Mus. natl. Hist. nat., Paris. Ser. 4, A. 15(1-4):19-24.

VERRILL, A.E. 1871. Descriptions of some imperfectly known and new ascidians from New England. Am. J. Sci. (3)1:5458, 93-100, 211, 212, 288-294, 443-446.

VERRILL, A.E. 1900. Addition to the Tunicata and Molluscoidea of the Bermudas. Trans. Connecticut Acad. Sci. 10:588-594.

WIEGMANN, A.F.A. 1835. Tunicata. Arch. Naturgesch. 1(1):309. 